\title{
A membránkötött Hyn [NiFe] hidrogenáz enzim struktúra-funkció analízise Thiocapsa roseopersicina-ban
}

Ph.D. értekezés

Szőri-Dorogházi Emma

Biológia Doktori Iskola

Témavezetők:

Prof. Kovács L. Kornél

Dr. Rákhely Gábor

Dr. Maróti Gergely

Szegedi Tudományegyetem Biotechnológiai Tanszék

Magyar Tudományos Akadémia Szegedi Biológiai Kutatóközpont, Biofizikai Intézet

Szeged

2012. 


\section{Tartalomjegyzék}

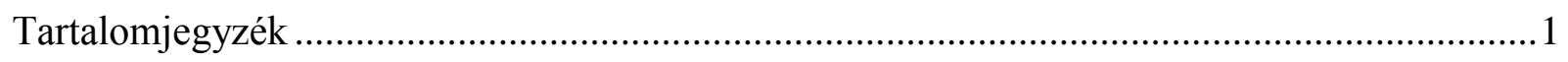

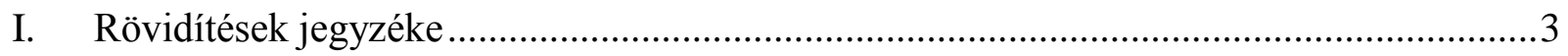

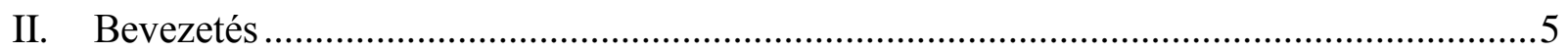

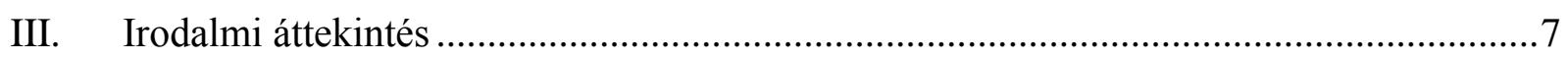

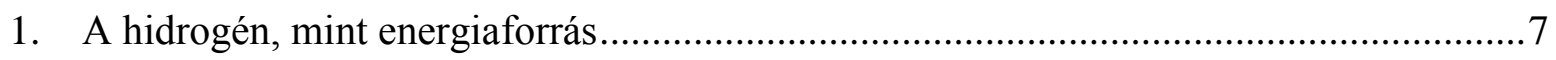

2. A hidrogenázok általános jellemzői, csoportosításuk, bioszintézisük................................7

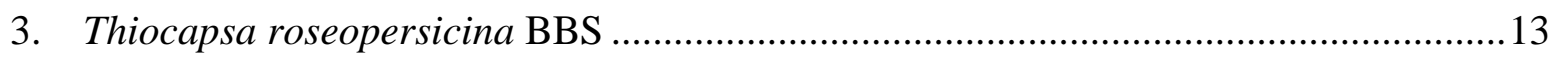

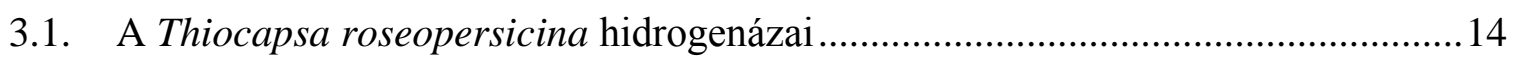

4. Struktúra-funkció kapcsolat a [NiFe] hidrogenázokban..............................................18

5. A proton kapcsolt elektrontranszfer jelentősége a biológiai rendszerekben ...................21

6. A [NiFe] hidrogenázok hisztidin gazdag motívuma....................................................22

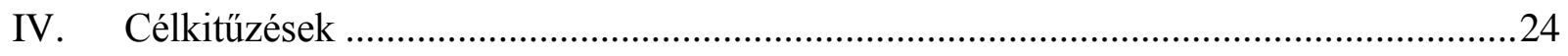

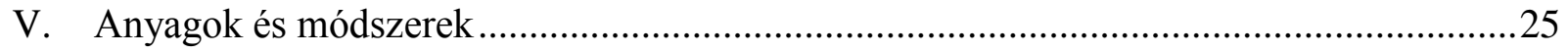

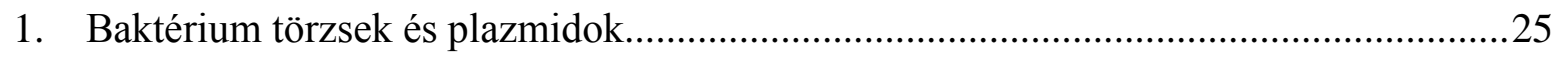

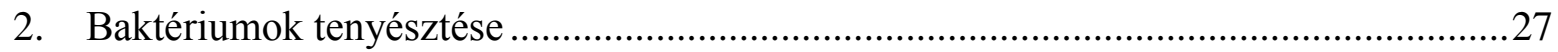

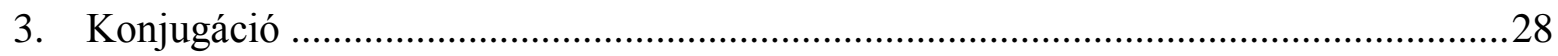

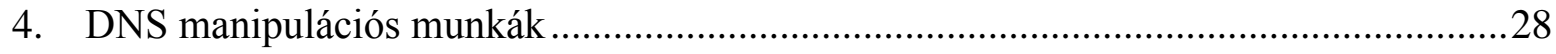

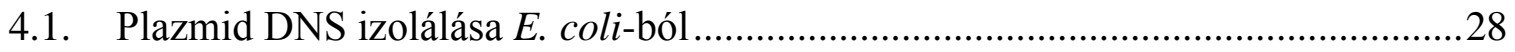

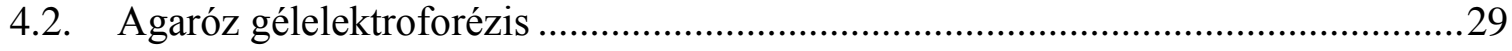

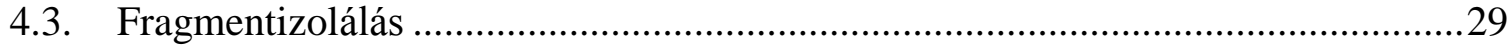

4.4. Emésztés restrikciós enzimekkel......................................................................29

4.5. Alkalikus foszfatáz kezelés ..........................................................................29

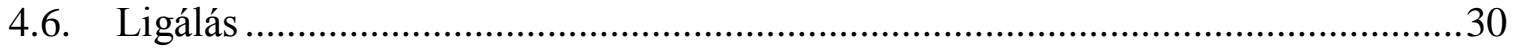

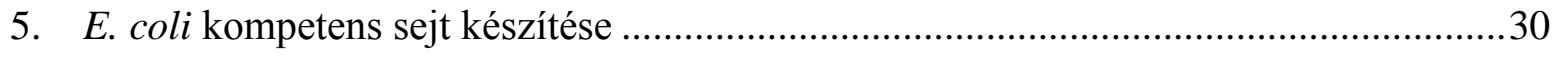

6. E. coli kémiai transzformálása.....................................................................................30

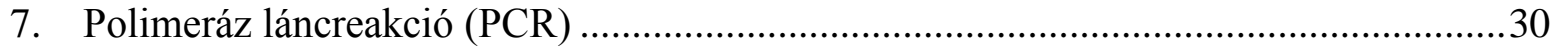

8. Nukleotid sorrend meghatározás …………...............................................................

9. Irányított mutagenezis ........................................................................................ 31

10. Membrán és szolubilis sejtfrakciók izolálása T. roseopersicina-ban ..........................33

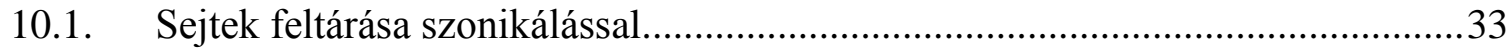

10.2. Membrán és szolubilis frakció elválasztása ultracentrifugával ............................33

11. Hidrogenáz aktivitás mérési módszerek ………………...............................................33 
11.1. In vivo hidrogéntermelés mérése gázkromatográffal.....................................33

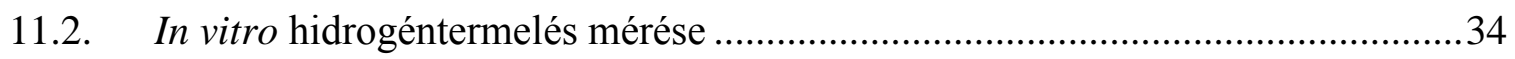

11.3. In vitro hidrogén felvevő aktivitás detektálása spektrofotométerrel ...................34

12. Fehérje mennyiségi meghatározása Lowry módszerrel (Micro-Lowry módszer)......35

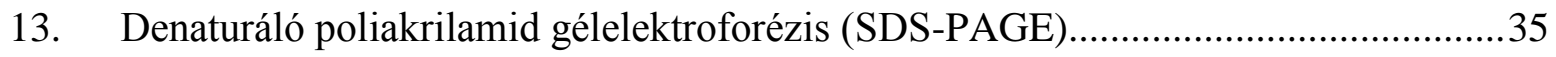

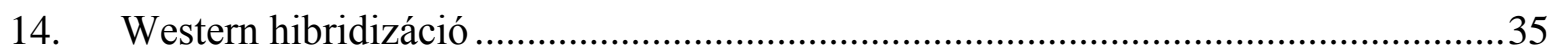

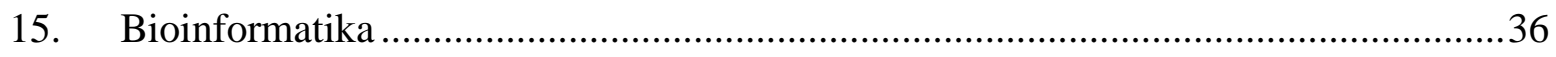

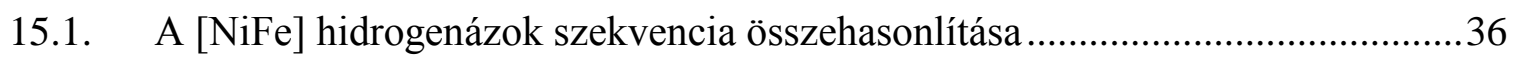

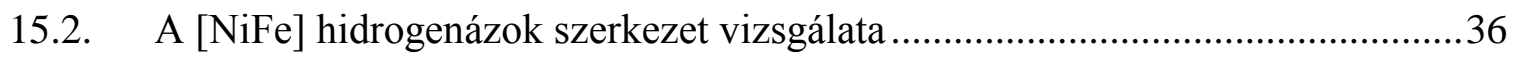

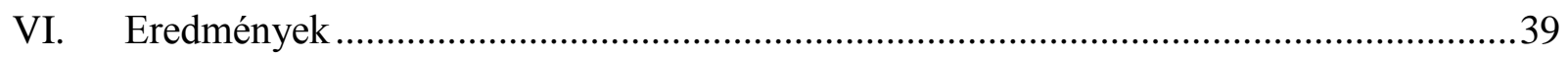

1. A His-gazdag motívum azonosítása a [NiFe] hidrogenázokban ................................39

2. A His-gazdag motívum funkcionális analízise T. roseopersicina HynL alegységében

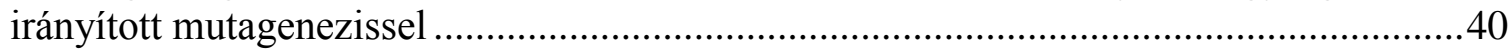

2.1. Az egyszeres-His mutánsok elkészítése ..........................................................40

2.2. Az egyszeres His-mutánsok aktivitásának vizsgálata in vivo és in vitro

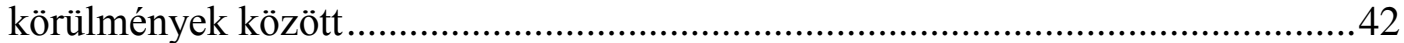

2.3. A mutáns enzimek stabilitásának és sejten belüli elhelyezkedésének vizsgálata ...44

2.4. A többszörös His-mutánsok és jellemzésük ....................................................45

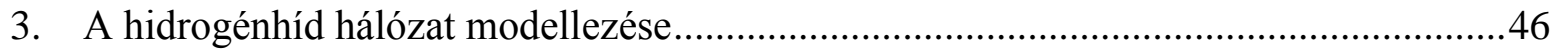

4. Az elméleti modell kísérletes bizonyítása ................................................................49

5. A D. fructosovorans-ban leírt Glu14-es útvonal jellemzése T. roseopersicina-ban ......52

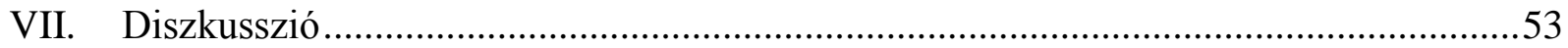

1. A membránkötött [NiFe] hidrogenázok His-gazdag régiójának lehetséges szerepe.......54

2. A $[\mathrm{NiFe}]$ hidrogenázok egy alternatív proton transzlokációs útvonala ........................57

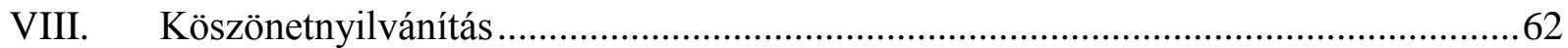

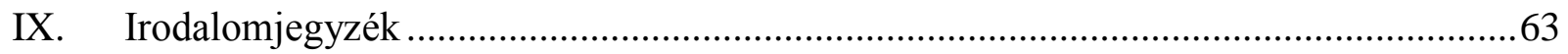

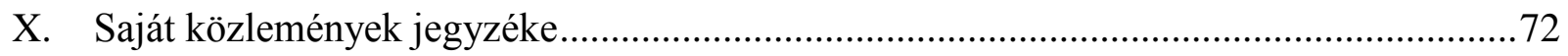

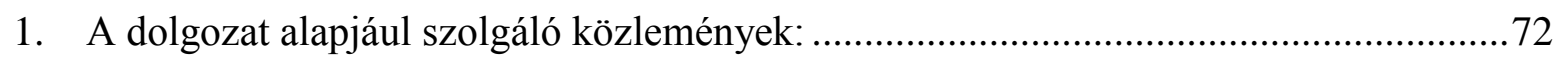

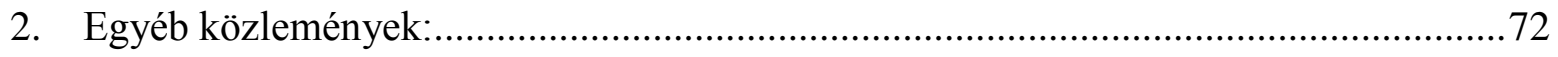

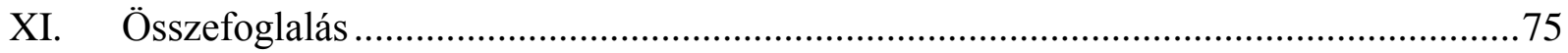

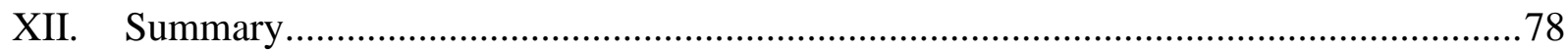




\section{Rövidítések jegyzéke}

Amp: ampicillin

APS: ammónium-perszulfát

ATP: adenozin-trifoszfát

bp: bázispár

CIAP (CIP): Borjú Vékonybél Alkalikus Foszfatáz

$\mathrm{CN}^{-}$: cianidion

CO: szén-monoxid

$\mathrm{CO}_{2}$ : szén-dioxid

COM: tömegközéppont (center of mass)

DMSO: dimetil-szulfoxid

DNS: dezoxiribonukleinsav

dNTP: dezoxinukleozid-trifoszfát

DTT: ditiotreitol

EDTA: etilén-diamin-tetraecetsav

Er: eritromicin

g: nehézségi gyorsulás

$\mathrm{Gm}$ : gentamicin

GTPáz: guanozin-trifoszfát hidroláz

$\mathrm{H}_{2}$ : hidrogén (molekuláris)

$\mathrm{kDa}$ : kilodalton (atomi tömegegység)

Km: kanamicin

LB: Luria-Bertani tápoldat

$\mathrm{N}_{2}$ : nitrogén

NAD: nikotinamid-adenin-dinukleotid

NADP: nikotinamid-adenin-dinukleotid-foszfát

$\mathrm{O}_{2}$ : oxigén

PCR: polimeráz láncreakció

PDB, PDB ID: fehérje adatbázis (Protein Data Bank) azonosítója

PIPES: 1,4-piperazin-dietánszulfonilsav

RNáz A: ribonukleáz A

RNS: ribonukleinsav 
rpm: percenkénti fordulatszám

SDS: nátrium-dodecil-szulfát

SDS-PAGE: denaturáló poliakrilamid gélelektroforézis

SOB: super optimal broth (tápanyagokban gazdag tápoldat)

Str: sztreptomicin

Tc: tetraciklin

TCA: triklórecetsav

TEMED: N,N,N',N'-tetrametil-etilén-1,2-diamin

TRIS: Trisz-(hidroximetil)-aminometán 


\section{Bevezetés}

Napjaink technológiái elsősorban a fosszilis energiahordozók (szén, földgáz, kőolaj) felhasználására épülnek, ez viszont hosszú távon a gazdaságosan kitermelhető kőolaj- és földgázkészletek kimerüléséhez vezet. A jelenlegi gazdaságpolitikai megfontolások szerint a még rendelkezésre álló készletek kitermelése akkor is megérné, ha a bányászatba fektetett energia meghaladná a kitermelt anyagból hasznosítható energiát. Ez azonban nem oldaná meg a globális energiaproblémát, hiszen a Föld népességének növekedésével energiaszükségletünk egyre nő, miközben a fosszilis energiahordozók készletei végesek. Továbbá kitermelésük és felhasználásuk során nagy mennyiségü üvegházhatást fokozó gáz (pl. szén-dioxid, nitrogénoxidok, metán, klórozott szénhidrogének) kerül a légtérbe, aminek következményeként a már napjainkban is tapasztalható globális felmelegedés Földünk klímájának megváltozásához vezethet. Mindez alternatív, tiszta és megújuló energiaforrások kutatására kell sarkalljon bennünket, még akkor is, ha szénhidrogén forrásaink jelenlegi készletei még hosszú évekre elegendőek lennének.

A számos alternatív megoldás közül a hidrogén gáz $\left(\mathrm{H}_{2}\right)$ igazán ígéretes jelöltnek tünik, hiszen elégetésekor víz keletkezik, és jelenleg is számos felhasználási területe ismert (pl. üzemanyag cellák). Molekuláris hidrogén elöállítható kémiai reakciókkal, a víz elektrolízisével, illetve biológiai rendszerek segítségével, biofotolízissel, fotofermentációval valamint sötét fermentációval. Ez utóbbi esetekben a protonok redukcióját a sokféle élőlényben megtalálható hidrogenáz, illetve nitrogenáz enzimek katalizálják.

A természetben a zöld algák (pl. Chlamydomonas reinhardtii) és cianobaktériumok a víz biofotolízise révén termelnek $\mathrm{H}_{2}$-t, mely folyamathoz csupán vizet és napfényt használnak. A folyamatban képződő elektronok a sejtekben a redox koenzimeket redukálják, melyeket utána hidrogenáz enzimeik hasznosítanak hidrogéntermelésük során. Miközben az elektronok a sejtmembránban elhelyezkedő elektron transzport rendszeren haladnak végig, a membránban a fotolízis során felszabaduló protonok áthelyeződése miatt töltéskülönbség jön létre. Az így kialakuló proton gradiens energiatartalma ATP szintézisében realizálódik. Viszont a biofotolízissel kapcsolatos $\mathrm{H}_{2}$ termelő folyamatok egyelöre még csak elvi szinten müködnek. A gyakorlati megvalósítás egyik fő gondja, hogy az aerob fotoszintézis során keletkező oxigén 
a hidrogenázok müködését gátolja. Emellett a folyamat fotokémiai hatékonysága is még meglehetősen alacsony, ami azt jelenti, hogy a fotoszintézisből származó energiának csak kis része fordítódik hidrogéntermelésre.

A fotoheterotróf $\mathrm{H}_{2}$ termelést (fotofermentáció) az anaerob körülmények között élő fotoszintetizáló baktériumok (Rhodobacter sp., Rhodospirillum sp., Rhodopseudomonas $s p$.) végzik napfény és szerves szubsztrátok (szerves savak), mint elektrondonorok, felhasználásával. Ezekben a folyamatokban oxigén nem képződik, így itt ez nem is számít gátló tényezőnek, mint a biofotolízis során. Ezen élőlények rendelkeznek hidrogenáz és nitrogenáz enzimekkel is, azonban hidrogéntermelésük elsősorban nitrogenáz enzimeik segítségével történik. Hidrogenázaik elsődleges feladata a nitrogenáz által termelt hidrogén visszavétele, annak visszaoxidálása, ezáltal pedig jelentősen befolyásolják a fotoheterotróf $\mathrm{H}_{2}$ termelés hatékonyságát. A fotofermentáció esetében is számolnunk kell gátló tényezőkkel, mint például az ammónium ionok $\left(\mathrm{NH}_{4}{ }^{+}\right)$, melyek a nitrogenáz enzim expresszióját gátolják. A végső energiamérleget a nitrogenázokhoz kapcsolódó reakciók viszonylag nagy energiaigénye is rontja (Oh és mts., 2011).

A biológiai hidrogéntermelés harmadik lehetősége, a fakultatív vagy obligát anaerob baktériumok (pl. Escherichia coli, Clostridium sp.) által végzett sötét fermentáció, melyhez ezen organizmusok a szerves anyagok (szerves hulladékok) széles körét képesek felhasználni egyedüli szén-, energia- és elektronforrásként. Bár a folyamat során az előbbiekhez képest több hidrogén termelődik, a keletkező melléktermékek miatt az ipari hasznosításhoz még a sötét fermentációhoz kapcsolódó hidrogéntermelő folyamatok is finomításra szorulnak (Kim és mts., 2011, Oh és mts., 2011).

Ahhoz, hogy képesek legyünk mikroorganizmusokkal, vagy a belölük izolált enzimekkel folyamatosan nagy mennyiségü hidrogént gazdaságosan előállítani, ismernünk kell az enzimek pontos szerkezetét, müködését, hogy ezáltal módosítani tudjuk őket a jobb és hatékonyabb hasznosítás érdekében. 


\section{Irodalmi áttekintés}

\section{A hidrogén, mint energiaforrás}

A természetben számos baktérium képes a $\mathrm{H}_{2}-\mathrm{t}$ energiaforrásként hasznosítani, melynek lényege a $\mathrm{H}_{2}$ specifikus enzimekkel történő oxidációja. A folyamat során felszabaduló elektronok a centrális elektronraktáron keresztül különféle terminális elektronakceptorra kerülnek. A protonok, a kialakuló transzmembrán proton gradiens révén ATP képződéséhez járulnak hozzá. Mint tudjuk az ATP pedig nélkülözhetetlen a sejtekben végbemenő létfontosságú folyamatokhoz, a különbözö anyagcsere folyamatoktól kezdve egészen a sejtek mozgásáig (Cammack és mts., 2001).

A mikroorganizmusok hidrogén metabolizmusában két enzimcsoport vesz részt: a nitrogenázok és a hidrogenázok. A nitrogenázok feladata elsősorban a légköri $\mathrm{N}_{2}$ megkötése, redukciója, miközben melléktermékként $\mathrm{H}_{2}$ keletkezik. Azonban az aerob és az anaerob körülmények közötti $\mathrm{H}_{2}$ oxidáció kulcsenzimei mégis a hidrogenázok, melyek az energia visszaforgatásán kívül, különféle reduktív folyamatokhoz szolgáltathatnak elektronokat. Ilyenek például a biogáz képződése, szulfát- és fémredukció vagy a denitrifikáció (Kovacs és mts., 2006).

A hidrogén metabolizmusra képes organizmusok legnagyobb része az Eubaktériumok és Archaebaktériumok doménjébe tartozik. Néhány alacsonyabb rendü eukarióta is képes hidrogént termelni hidrogenázai révén, melyek vagy az ún. hidrogenoszómákban találhatóak meg, mint egyes parazita protozoákban (Trichomonas vaginalis), és anaerob gombákban (Neocallimastix frontalis), vagy az egysejtü zöld algák kloroplasztiszaiban (Chlamydomonas, Scenedesmus).

\section{A hidrogenázok általános jellemzői, csoportosításuk, bioszintézisük}

A hidrogenázok a hidrogén metabolizmus egyik kulcsenzimét képviselik, melyek a molekuláris hidrogén reverzibilis, heterolitikus hasítását a $\mathrm{H}_{2} \leftrightarrow 2 \mathrm{H}^{+}+2 \mathrm{e}^{-}$egyenlet szerint 
katalizálják (Vignais és mts., 2007). Az ismert hidrogenázok többsége vas-kén fehérje két fémionnal az enzim aktív centrumában. Ezen fématomok típusától függően beszélhetünk [NiFe], illetve [FeFe] hidrogenázokról. Néhány metanogén organizmusban vas-kén klasztert (FeS klaszter) nem tartalmazó, hidrogéntermelő metilén-tetrahidrometanopterin dehidrogenáz (Hmd) enzimeket találtak, melyeket ebböl adódóan FeS-csoport mentes, vagy [Fe] hidrogenázoknak is szoktak nevezni. Ez a három, filogenetikailag is különböző csoport közös tulajdonsága, hogy rendelkeznek egy funkcionális alapegységgel, mely az adott csoportban konzervált. Ez az alapegység az egyes fehérje alegységeket vagy doméneket jelenti, melyek az aktív centrumot tartalmazzák, és az enzimek ezen alapegysége nélkülözhetetlen a müködéséhez (Vignais és mts., 2001, Vignais és mts., 2007).

\subsubsection{A Hmd vagy [Fe] hidrogenázok}

A Hmd enzimeket elöször a Methanothermobacter marburgenis-ben írták le. Ezen hidrogenázok nem tartalmaznak sem nikkelt, sem FeS klasztert, és nikkel korlátozott körülmények között nevelt sejtekben indukálódnak (Zirngibl és mts., 1992, Afting és mts., 1998). A két 38 kDa-os alegységböl álló, homodimer formájú enzim egy Fe tartalmú specifikus kofaktort köt. Fontos megemlíteni, hogy a [Fe] hidrogenázok nem katalizálják a [NiFe] és [FeFe] hidrogenázokra általánosan jellemző $\mathrm{H}_{2} \leftrightarrow 2 \mathrm{H}^{+}+2 \mathrm{e}^{-}$reverzibilis reakciót (Vignais és mts., 2007). Részt vesznek viszont a metanogenezisben, ahol az $\mathrm{N}^{5}, \mathrm{~N}^{10}$-meteniltetrahidrometanopterin $\mathrm{H}_{2}$-nel való reverzibilis reakcióját katalizálják, miközben $\mathrm{N}^{5}, \mathrm{~N}^{10}$ metilén-tetrahidrometanopterin és $\mathrm{H}^{+}$keletkezik (Hartmann és mts., 1996).

\subsubsection{A[FeFe] hidrogenázok}

[FeFe] hidrogenázokat elsősorban anaerob prokariótákban és néhány anaerob eukariótában találhatunk. Nagy részük oxigénre nagyon érzékeny, bár vannak kivételek is, mint például a Desulfovibrio vulgaris Hildenborough periplazmatikus enzime (Adams 1990). A [FeFe] hidrogenázok főként $\mathrm{H}_{2}$ termelésben játszanak fontos szerepet (Vignais és mts., 2007), lehetnek mono-, di-, tri-, vagy tetramerek (Vignais és mts., 2001). A kb. 350 aminosavból álló konzervált domén (más néven H-klaszter) tartalmazza az aktív centrumot, 
mely a fémionok közül csak Fe ionokat tartalmaz, valamint [4Fe4S] klasztert, amely cisztein aminosavakon keresztül kapcsolódik a fémcentrumhoz és a fehérjemátrixhoz. Az aktív centrum Fe ionjaihoz nem fehérjetermészetü, $\mathrm{CN}^{-}$, és $\mathrm{CO}$ ligandok is kapcsolódnak (Peters és mts., 1998, Nicolet és mts., 1999, Peters 1999). A katalitikus alegység egyébként igen nagy méretbeli variabilitást mutat, mely a H-klasztert is magába foglaló konzervált doménen kívül gyakran tartalmaz további doméneket, melyek további FeS klasztereket illetve egyéb szubsztrátkötő doméneket hordoznak (Adams 1990).

\subsubsection{A [NiFe] hidrogenázok}

A [NiFe] hidrogenázok képezik a hidrogenázok legszámosabb és leginkább kutatott csoportját. Az enzim katalitikusan fontos magja egy $\alpha$ és egy $\beta$ alegységből álló heterodimer. A kb. 60 kDa-os nagy alegységben (az $\alpha$-alegység) található a két fématomot tartalmazó aktív centrum, míg a kis alegység ( $\beta$ alegység) nagyjából 30 kDa nagyságú, mely az enzim aktív centruma és a megfelelő elektrondonor/akceptor közötti elektrontranszferért felelős $\mathrm{FeS}$ kockákat tartalmazza. A két alegység viszonylag nagy felületen érintkezik egymással és így egy globuláris heterodimert alkotnak (Vignais és mts., 2007).

A nagy alegység belsejében található $\mathrm{Ni}$ és $\mathrm{Fe}$ ionok négy cisztein révén koordinálódnak a fehérjéhez. A $\mathrm{Fe}$ ionhoz nem fehérjetermészetü ligandumok is kapcsolódnak: általában $1 \mathrm{CO}$ és $2 \mathrm{CN}^{-}$ligand (R. P. Happe és mts., 1997, Pierik és mts., 1999, Volbeda és mts., 2002) (1. ábra). 


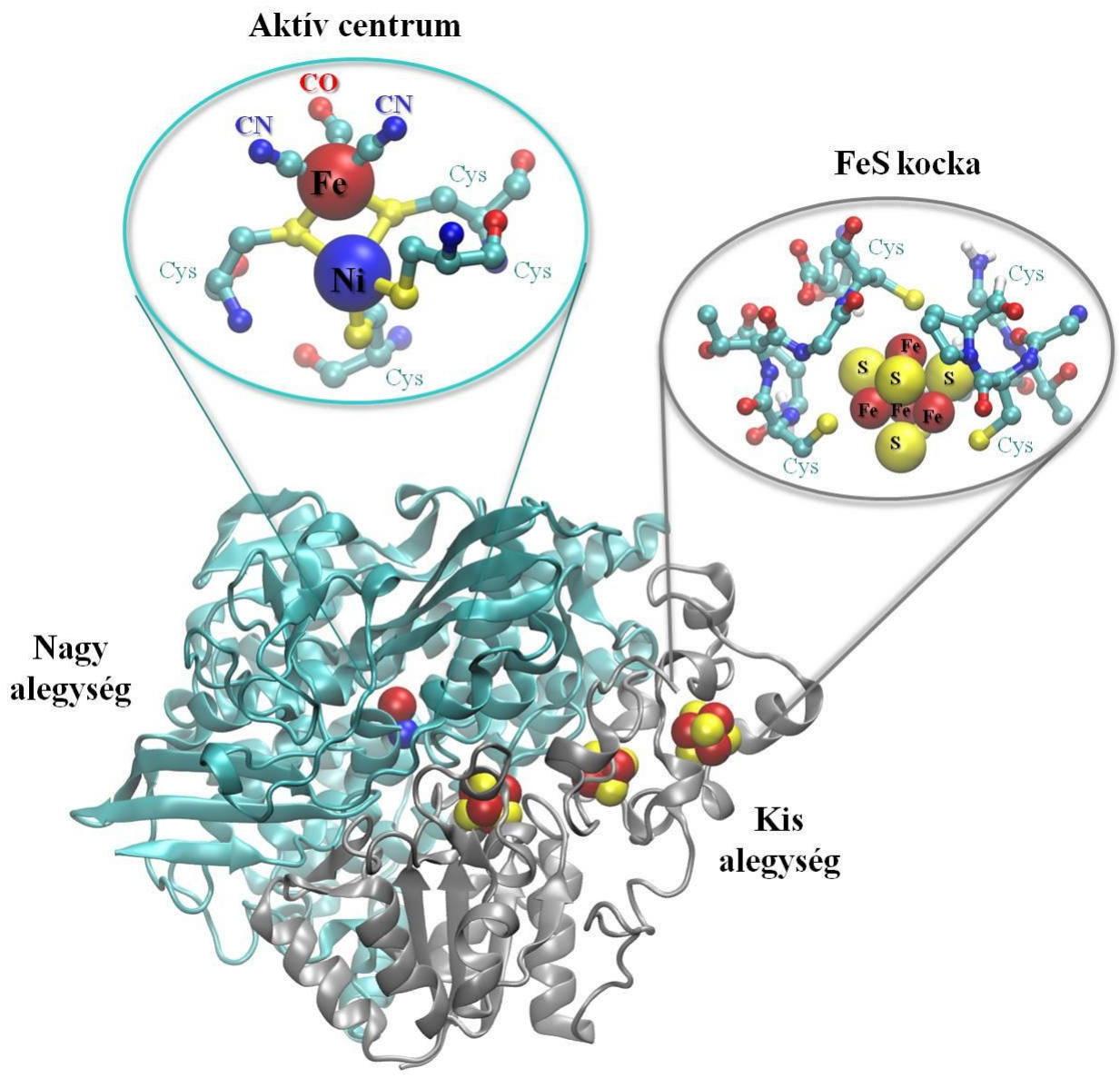

1. ábra: A [NiFe] hidrogenázok térszerkezete. A nagy alegység zöld színnel van jelölve, szürkével a kis alegység, az aktív centrum felépítése és a FeS kockák elrendeződése pedig kiemelve látható.

A kis és nagy alegység szekvencia analízise alapján a [NiFe] hidrogenázokat négy csoportba sorolták, mely jól egybevethető az enzimek fiziológiás funkciójával (Vignais és mts., 2001).

1. csoport: a hidrogénfelvevő [NiFe] hidrogenázok

Ezen csoportba tartozó enzimek membránkötöttek, a hidrogént energiaforrásként képesek felhasználni, azaz a $\mathrm{H}_{2}$ oxidációját összekapcsolhatják anaerob elektronakceptorok redukciójával, mint a $\mathrm{NO}_{3}{ }^{-}, \mathrm{SO}_{4}{ }^{2-}$, fumársav (anaerob respiráció), $\mathrm{CO}_{2}$ (fotoszintetikus széndioxid redukció) vagy az $\mathrm{O}_{2}$ redukciójával (aerob légzés). Első lépésben a hidrogénből nyert elektronok egy citokróm b típusú transzmembrán fehérjén keresztül a légzési lánchoz kapcsolódó kinon raktárba kerülnek. A redukált kinonokról az elektronok a terminális 
elektronakceptorokra jutnak, miközben a sejtek az energiát transzmembrán elektrokémiai potenciál különbség, illetve végül ATP formájában tudják tárolni (Vignais és mts., 2007). Az enzimek szerkezetét tekintve jellemző, hogy kis alegységük N-terminálisán hosszú szignál peptiddel rendelkeznek, melyet a Tat (twin-arginin translocation) transzport útvonalhoz tartozó fehérjék felismernek és a végleges szerkezetét elnyert enzimet kijuttatják a membránon keresztül a periplazmába (Sargent és mts., 2006).

Ilyen hidrogénfelvevő hidrogenázok képviselöit megtalálhatjuk például a Wolinella succinogenes, Aquifex aeolicus, Thiocapsa roseopersicina és néhány Desulfovibrio fajban.

A nitrogénfixáló baktériumok (például Rhizobium leguminosarum, Azotobacter sp.) is rendelkeznek hidrogénfelvevő típusú $[\mathrm{NiFe}]$ hidrogenázzal, mely révén képesek a nitrogenáz enzim által termelt molekuláris hidrogén visszavételére, aminek eloxidálásával a sejt pótolni tudja a nitrogénfixálás folyamata során keletkező energiaveszteséget.

2. csoport: a citoplazmatikus $\mathrm{H}_{2}$ szenzor és a cianobakteriális típusú hidrogén felvevő [NiFe] hidrogenázok

A citoplazmatikus $\mathrm{H}_{2}$ szenzor fehérjék nem rendelkeznek szignál szekvenciával kis alegységükön, oxigénnel szemben nem érzékenyek, feladatuk a környezetben lévö hidrogén jelenlétének érzékelése, ami által részt vesznek a hidrogénfelvevő hidrogenázok (hydrogen uptake, Hup) szintézisének szabályozásában (Kleihues és mts., 2000). Ilyen $\mathrm{H}_{2}$ szenzor enzimeket találunk Bradyrhizobium japonicum, Ralstonia eutropha, vagy például Rhodobacter capsulatus-ban (Black és mts., 1994, Dischert és mts., 1999, Lenz és mts., 2002)

A cianobaktériumok (Nostoc és Anabena variabilis (Oxelfelt és mts., 1998, T. Happe és mts., 2000)) hidrogénfelvevő enzimei a sejt citoplazmájában vagy a tilakoid membránban lokalizálódnak, aktiválódásuk kapcsolatban áll a nitrogenáz enzimrendszer múködésével, $\mathrm{N}_{2^{-}}$ fixáló körülmények között indukálódnak.

3. csoport: kétirányú, heteromultimer, citoplazmatikus [NiFe] hidrogenázok

Képviselöik reverzibilisen müködnek, feladatuk a nukleotid típusú kofaktorok ( $\mathrm{F}_{420}$, NAD, NADP) redukciója illetve visszaoxidálása. Általában rendelkeznek egy kis és egy nagy alegységből álló hidrogenáz enzimrészlettel, melyhez a több alegységes, a kofaktorokat 
megkötő enzimrészlet kapcsolódik. Számos képviselőjük található az Archaebaktériumok közé tartozó fajokban (Pyrococcus furiosus, Thermococcus litoralis), de az Eubaktériumok, mint például $R$. eutropha (Schneider és mts., 1976), T. roseopersicina (Rakhely és mts., 2004, J. Maroti és mts., 2010), cianobaktériumok (például Synechocystis fajok (Appel és mts., 1996)) is rendelkeznek ilyen fehérjékkel.

4. csoport: több alegységes, hidrogéntermelő, energiakonzerváló, membránkötött hidrogenázok

A multimer (hat vagy több alegységből álló) enzimek zöme az Archaebaktériumok képviselőiben található meg (például Methanosarcina barkeri (Kunkel és mts., 1998), Methanothermobacter fajok (Tersteegen és mts., 1999), és Pyrococcus furiosus (Sapra és mts., 2000, Silva és mts., 2000)). A glikolízis során képződő redukált ferredoxin felhasználásával képesek hidrogént fejleszteni. További képviselőik például az E. coli és Rhodospirillum rubrum hidrogenázai, melyek müködése szorosan kapcsolt a C1-es komponensek (pl. CO vagy hangyasav) anaerob oxidációjához, és a segítségükkel a sejtek megszabadulnak a folyamatban keletkező felesleges redukáló ekvivalensektől (Bohm és mts., 1990, Sauter és mts., 1992, Fox és mts., 1996, Fox és mts., 1996).

Amint láttuk, a hidrogenázok által katalizált igen egyszerü reakció számos különböző metabolikus folyamattal áll összefüggésben a sejtekben, minek következtében a hidrogenázok funkciója is igen sokféle. Ugyancsak igaz, hogy a különböző múködésủ és feladatú enzimek sejten belüli elhelyezkedésükben is sokszor eltérnek. Sok baktérium két vagy több különböző funkciójú és elhelyezkedésű hidrogenázt is tartalmaz, így képesek gyorsan és hatékonyan alkalmazkodni a változó körülmények előidézte redox- és energiaigényhez. Az enzimek [NiFe] aktív centrumának bonyolult felépítése, funkciójuk és szerkezetük komplexitása, valamint változatos sejten belüli elhelyezkedésük igen összetett bioszintetikus útvonalat feltételez.

\subsubsection{A [NiFe] hidrogenázok érése}

A [NiFe] hidrogenázok bioszintézis vizsgálatainak egyik leginkább tanulmányozott modellje az E. coli 3-as hidrogenázának érése. A folyamatban résztvevő legfontosabb fehérjék 
a hidrogenáz pleiotróp, azaz Hyp fehérjék (HypA, HypB, HypC, HypD, HypE, HypF) és az adott enzimre specifikus endopeptidázok.

A mai ismereteink szerinti modell a következö: a HypC (egy kis chaperon jellegü fehérje) és HypD (FeS tartalmú fehérje) fehérjék komplexet alkotnak (Blokesch és mts., 2004), mely a Fe iont köti és szállítja az éretlen nagy alegység fehérjéhez. Ezt követően a HypC tartja a fémionok beépítéséhez nyitott konformációban az éretlen nagy alegységet (Magalon és mts., 2000, Blokesch és mts., 2002). A CN és valószínüleg a CO ligandok szintézise is a HypF-HypE komplex révén valósul meg (Reissmann és mts., 2003). A $\mathrm{CN}^{-}$ ligandok a karbamoil-foszfátról származnak, melyet a HypF-HypE komplex több, ATP-t igénylő lépésben alakít ki, és kapcsol a HypC-HypD komplex által kötött Fe-hoz. A ligandumokkal ellátott $\mathrm{Fe}$ ionnak az éretlen nagy alegységbe történő beépülése után következhet a Ni beépítése. Ebben a lépésben két újabb segédfehérje vesz részt, a HypA és HypB. A Bradyrhizobium japonicum esetében igazolták, hogy a GTPáz funkcióval rendelkező HypB nemcsak a Ni beépítéséért, de polihisztidin „nyúlványa” révén a Ni raktározásáért is felelős (Fu és mts., 1995). Az aktív centrum megfelelö összeszerelődése és a HypC fehérje disszociációja után (Magalon és mts., 2000), a nagy alegység érésének utolsó lépéseként, a fehérje C-terminális peptidjének levágására kerül sor specifikus endopeptidázok segítségével (Theodoratou és mts., 2005). A hidrogenázok bioszintézisének folyamata, az enzim kis és nagy alegységének egymástól független érése után, az alegységek oligomerizációjával végződik.

Ez a modell alapvetően érvényes a Thiocapsa roseopersicina hidrogenázainak érésére is. Azonban csoportunk a T. roseopersicina hidrogenázai érésének vizsgálataiból a fentiekben részletezett általános bioszintézis modellt néhány újabb megfigyeléssel is kiegészítette (G. Maroti és mts., 2003, G. Maroti és mts., 2010).

\section{Thiocapsa roseopersicina $\mathrm{BBS}$}

Modellorganizmusunk, a Thiocapsa roseopersicina BBS, egy Gram-negatív, fotoszintetizáló, bíbor kénbaktérium, mely a Chromatiaceae családba tartozik. Az első izolátumok a Jeges-tengerből származtak (Bogorov 1974). Az 1,2-3 $\mu \mathrm{m}$ átméröjü coccusok 
nem mozgékonyak. A $T$. roseopersicina természetes élőhelyén a hőmérséklet, az oxigénkoncentráció és a kénkoncentráció állandó változása következtében nagy türöképességgel rendelkezik (Visscher és mts., 1990). Laboratóriumi körülmények között optimális növekedési hőmérséklete $24-28^{\circ} \mathrm{C}$ között van, $30^{\circ} \mathrm{C}$ felett növekedése gátolt (Bogorov 1974). A vad típusú törzs folyadék kultúrája 5-6 nap alatt nő fel, lemezen pedig 14 nap alatt alkot telepeket. A cianobaktériumoktól eltérően, melyek elektrondonorként vizet használnak és a fotoszintézis melléktermékeként oxigént termelnek, az anaerob fototróf baktériumok nem képesek vízbontásra, nem termelnek oxigént. Fotoszintézisük elektronigényét redukált kénvegyületekkel fedezik. A Thiocapsa roseopersicina fototróf körülmények között elektrondonorként redukált kénvegyületeket (tioszulfát, szulfid, elemi kén stb.), szerves szubsztrátokat (pl. ecetsav), de akár molekuláris hidrogént is képes hasznosítani. Aerob vagy mikroaerofil körülmények között sötétben kemolitoautotróf életmódot folytat (Kondratieva és mts., 1976). Oxigén jelenlétében, ecetsavon és glükózon heterotróf módon is tud növekedni. Amennyiben tápoldata alternatív nitrogénforrást nem tartalmaz, nitrogenáz enzimrendszere segítségével a légköri nitrogén megkötésére is képes (Bogorov 1974), a reakció melléktermékeként pedig hidrogén képződik. Hidrogén metabolizmusának kulcsenzimei a [NiFe] hidrogenázok és a nitrogenáz enzimrendszer.

\subsection{A Thiocapsa roseopersicina hidrogenázai}

A Thiocapsa roseopersicina négy funkcionálisan aktív hidrogenázzal rendelkezik (Hyn, Hup, Hox1, Hox2), melyek in vivo szerepükben, sejten belüli elhelyezkedésükben és felépítésükben különböznek egymástól (Kovacs és mts., 2005, J. Maroti és mts., 2010). Hidrogenázai közül kettő (a Hyn és Hup) a sejtmembránhoz kapcsolódik, míg Hox típusú enzimei (Hox1 és Hox2) a citoplazmában találhatóak (2. ábra). A Hyn és a Hup enzimek struktúrfehérjéi nagy homológiát mutatnak: a kis alegységek (HynS és HupS) 46\%-ban, a nagy alegységek (HynL és HupL) 58\%-ban azonosak egymással (Rakhely és mts., 1998). Az alegységek molekulatömege szinte megegyező: a HynS 34kDa, a HupS 36kDa molekulatömegü, míg a HynL 64kDa, a HupL pedig 65kDa (Rakhely és mts., 1998). Mindkét membránkötött hidrogenáz kis alegységének N-terminálisán megtalálható a Tat (twwin-arginin transport) útvonalra jellemző szignál szekvencia (Sargent és mts., 1999), mely arra enged 
következtetni, hogy ezen enzimek a Tat-rendszer segítségével jutnak a sejtmembrán periplazmatikus oldalára. A Hox enzimek nem rendelkeznek a transzporthoz szükséges szignállal.
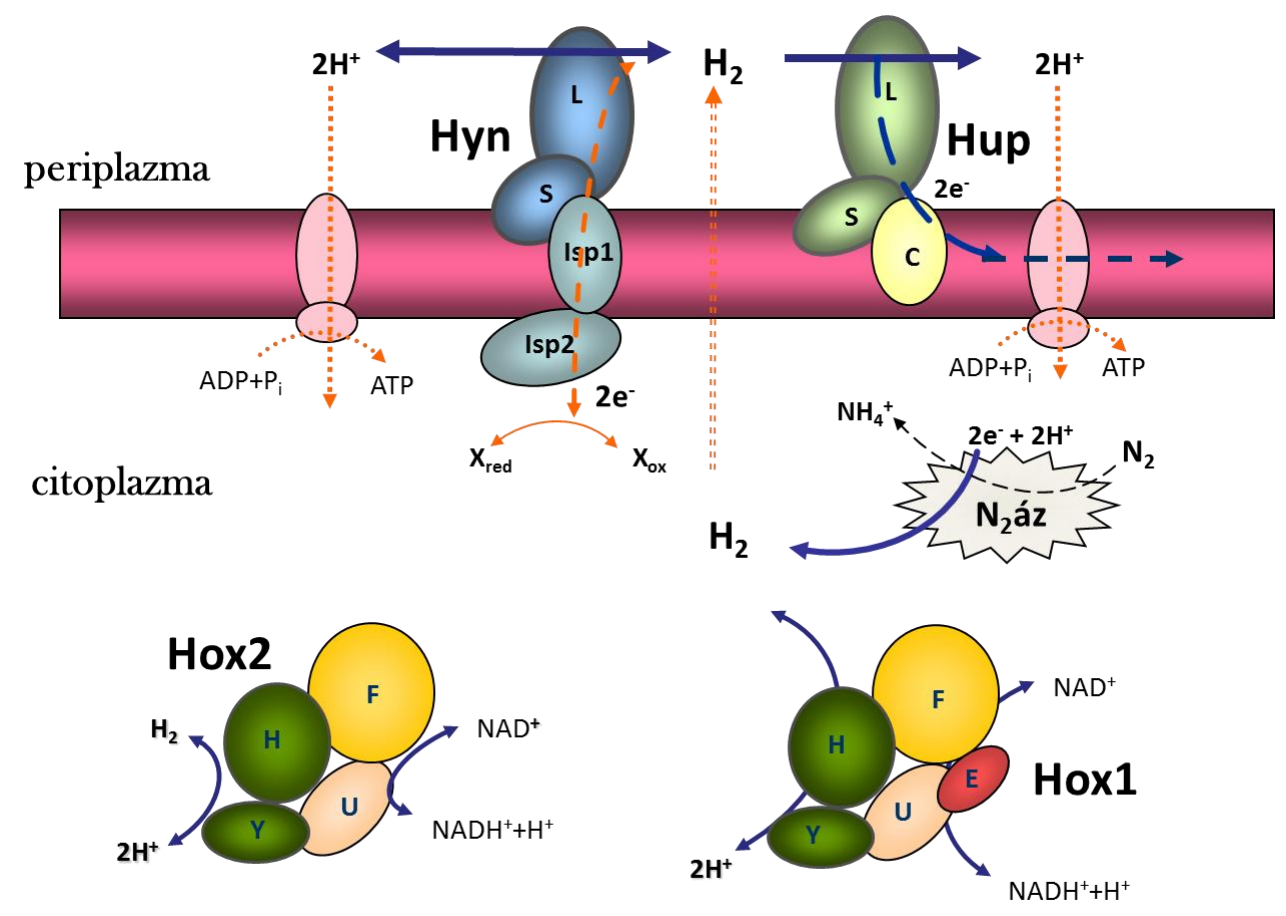

2. ábra: A Thiocapsa roseopersicina funkcionális hidrogenázai: membránkötött enzimek: Hyn és Hup; citoplazmatikus enzimek: Hox1 és Hox2.

Egy további, hidrogenázt kódoló régió is megtalálható a $T$. roseopersicina genomjában, viszont ezek a gének (hupTUV) nem expresszálódnak (Kovacs és mts., 2005). A T. roseopersicina hupUV által kódolt enzim homológjai más baktériumokban (HupUV a Rhodobacter capsulatus-ban és HoxBC a Ralstonia eutropha-ban) szabályozó szerepet töltenek be. A sejt környezetében lévő hidrogén mennyiségétől függően szabályozzák a Hup típusú enzimek expresszióját. Fontos megjegyezni, hogy a hidrogenázok többségétől eltérően ezek a szabályzó típusú enzimek oxigénnel szemben nem érzékenyek (Dischert és mts., 1999, Lenz és mts., 2002). 


\subsubsection{A Hyn hidrogenáz}

A Hyn hidrogenáz, korábbi nevén Hyd (Rakhely és mts., 1998) egy membránkötött, kétirányú enzim, mely kiemelkedő stabilitási tulajdonságokkal rendelkezik, megőrzi katalitikus aktivitását még a fotoszintetikus membránból való tisztítást követően is (Kovacs és mts., 1990). Struktúrgénjeinek elrendeződése szokatlan, az operonban a kis és a nagy alegységet kódoló gének között két nyitott leolvasási keret található (isp1, isp2), melyek a Desulfovibrio vulgaris hmc operonjának 5-ös és 6-os nyitott leolvasási keretével mutatnak homológiát (Rakhely és mts., 1998). A hmc operon termékei (Hmc1-6) a szulfát redukálásához a periplazmatikus térből a hidrogenáz enzimtől elektronokat szállítanak át a membránon. A transzmembrán elektrontranszportban a Hmc5 vesz részt, míg a Hmc6 a citoplazmatikus oldalon található (Rossi és mts., 1993). Az in silico elemzésekből kiderült, hogy az Isp1 transzmembrán doménekkel és b-típusú hem-kötőhellyel rendelkezik, feltételezhetően egy transzmembrán redox fehérje. Az Isp2 egy látszólag szolubilis fehérje, mely a heterodiszulfid reduktázokhoz mutat hasonlóságot (Rakhely és mts., 1998). Csoportunk korábbi kutatási eredményei bizonyították, hogy az isp gének valódi fehérjéket kódolnak. Mindkét protein szükséges a Hyn hidrogenáz megfelelö in vivo aktivitásához, míg hiányuk in vitro körülmények között, amikor mesterséges elektronakceptort vagy donort használtak a hidrogenázok katalizálta redox folyamat vizsgálatához, nem okozott jelentős aktivitásváltozást az enzim müködésében. Hiányuk nem befolyásolta az enzim expresszióját sem (Palagyi-Meszaros és mts., 2009). Az Isp fehérjék nagy valószínüséggel szerepet játszanak a Hyn hidrogenázhoz kötődő elektrontranszferben, és összekapcsolják ezt az enzimet a sejten belüli kénanyagcserével. A hynS-isp1-isp2-hynL gének együttesen íródnak át (Rakhely és mts., 1998) és szabályzásuk az Fnr rendszerhez kötődik (Kovacs és mts., 2005).

\subsubsection{A Hup hidrogenáz}

A T. roseopersicina másik membránkötött hidrogenáza a HupSL enzim (hydrogen uptake), melynek elsődleges feladata a sejtekben a nitrogenáz enzim által termelt hidrogén visszavétele (Vignais és mts., 2001). A kis és a nagy alegységet kódoló géneket is magába

foglaló operonban (hupSLCDHIR) a hupS és hupL gének közelében található a hupC gén 
(Colbeau és mts., 1994), mely egy citokróm b-típusú fehérjét kódol, jelenléte fontos a Hup enzim in vivo aktivitásához, feladata pedig feltehetően az elektronok továbbítása a Hup fehérjéről a kinon-raktár irányába. A Hup hidrogenáz expressziója igen érzékeny az oxigénre, a sejt redox állapotára és kapcsolatban van a Hox 1 hidrogenáz expressziójával, a Hox 1 enzim deléciójakor a Hup expressziós szintje is jelentősen lecsökkent (Palagyi-Meszaros és mts., 2009).

\subsubsection{A Hox1 hidrogenáz}

A hoxlEFUYH gének által kódolt heteropentamer enzim esetében a Hox1FU a $\mathrm{NAD}^{+} / \mathrm{NADH}$ redox reakció katalizálásáért, míg a Hox1YH a hidrogenáz aktivitásért felelős alegységek (Friedrich és mts., 1993, Rakhely és mts., 2004). A T. roseopersicina esetében egy további alegység is kapcsolódik a fehérjéhez, a Hox1E, mely alegység föként a cianobakteriális Hox hidrogenázokra jellemzö (Schmitz és mts., 2002, Tamagnini és mts., 2002, Rakhely és mts., 2004). Korábbi eredményeinkből kiderült, hogy ezen alegység hiánya hatással van a hidrogenáz aktivitására in vivo, tehát, amikor az enzim aktivitásához a fiziológiás elektronakceptorra vagy donorra van szükség. Az enzim in vitro aktivitását viszont nem befolyásolta, hiszen ilyekor mesterséges elektronakceptor vagy donor van a rendszerben, nagy feleslegben. Ezek az eredmények a Hox1E alegységnek a Hox1 hidrogenázhoz kapcsolódó feladatára utaltak; nagy valószínüséggel az elektrontranszferben játszik fontos szerepet (Rakhely és mts., 2004). Az affinitás-peptiddel ellátott Hox1E alegység segítségével csoportunkban tisztítani tudták az enzim többi alegységét is (Palagyi-Meszaros és mts., 2009). A Hox1 hidrogenáz valódi kétirányú enzimként müködik, ami azt jelenti, hogy hidrogéntermelésre képes nitrogenáz-gátolt körülmények között, illetve a nitrogenáz enzim által végzett nitrogénfixálás során képződő hidrogén visszavételét is végzi (Rakhely és mts., 2004). 


\subsubsection{A Hox2 hidrogenáz}

A $T$. roseopersicina utolsóként leírt [NiFe] hidrogenáza a Hox2, mely a hox $2 F U Y H$ gének által kódolt heterotetramer (J. Maroti és mts., 2010). A Hox1-hez hasonlóan a Hox2FU a diaforáz, míg a Hox2YH a hidrogenáz egységét jelenti az enzimnek. A Hox2 esetében azonban nem található meg a cianobakteriális típusú Hox enzimekre jellemző ún. ötödik alegység, a HoxE. A Hox2 alegységei a Methylococcus capsulatus ugyancsak tetramer, szolubilis hidrogenázával mutatják a legmagasabb fokú homológiát. Míg a Hox1 müködése erősen kapcsolódik a sejt kén-metabolizmusához (Rakhely és mts., 2004, Rakhely és mts., 2007), a Hox 2 nem képes a tioszulfátot közvetlen elektronforrásként hasznosítani. A sejtek növesztéséhez használt tápoldat alacsony tioszulfát tartalma mellett sikerült igazolni, hogy a Hox2 glükózt használ közvetlen elektrondonorként, ami valószínüsíti kapcsolódását a sejt glükóz metabolizmusához (J. Maroti és mts., 2010).

\section{Struktúra-funkció kapcsolat a [NiFe] hidrogenázokban}

Az enzimek strukturális elemei és az egyes enzimatikus funkciók kapcsolatának vizsgálatára használható egyik lehetséges módszer az irányított mutagenezis, mely technika alkalmazásával lehetőség nyílik egy-egy konkrét aminosav vagy akár egy kisebb motívum szerepének specifikus vizsgálatára. Ehhez azonban ismerni kell az adott enzim elsődleges szekvenciáját, illetve a kísérletek megtervezéséhez hasznos információkat kaphatunk a vizsgálandó fehérje, vagy az azzal nagyfokú homológiát mutató enzim kristályszerkezetéből is. Szulfát-redukáló baktériumok esetében ez idáig hat periplazmatikus [NiFe] hidrogenáz kristályszerkezetét írták le (Volbeda és mts., 1995, Higuchi és mts., 1997, Montet és mts., 1997, Garcin és mts., 1999, Matias és mts., 2001, Marques és mts., 2010), illetve a közelmúltban egy nem szulfát redukáló baktérium, az Allochromatium vinosum membránkötött [NiFe] hidrogenázát is sikerül kikristályosítani, szerkezetét meghatározni (Ogata és mts., 2010). Ezek a szerkezetek szolgáltak a későbbiekben modellként a [NiFe] hidrogenázok bizonyos strukturális elemei és az enzim funkciója közötti kapcsolatok 
tanulmányozásához. A különböző fajokból származó kristályszerkezetek összehasonlításával próbálták megjósolni, hogy az egyes enzimek aktív centrumában, illetve annak közvetlen környezetében tapasztalható szerkezeti különbségek hogyan befolyásolhatják a hidrogenázok aktivitását. Továbbá számos kísérletet végeztek annak érdekében, hogy feltérképezzék az enzim belsejében lévő aktív centrum és a fehérje felszíne közötti szubmolekuláris útvonalakat, melyek esetlegesen a szubsztrátok (molekuláris hidrogén, proton, elektron), vagy az enzim inhibítor molekuláinak (oxigén, $\mathrm{CO}$ ) csatornájaként szolgálhatnak az enzimkatalízis során (Montet és mts., 1997, Vignais és mts., 2001, Volbeda és mts., 2002, Fontecilla-Camps és mts., 2007).

Amíg kísérletes eszközökkel kevés, vagy nehezen szerezhető információ ezen csatornák térbeli elrendeződéséről, addig a számításos kémiai és bioinformatikai módszerek megoldást jelenthetnek erre. Így például molekuladinamikai számítások segítségével sikerült azonosítani azt a csatornát, mely összekötve a fehérje belsejében lévő aktív centrumot a fehérje felszínével, a molekuláris hidrogén hidrogenázokba való ki- és belépésének feltételezett útvonala. A Desulfovibrio gigas $[\mathrm{NiFe}]$ hidrogenázának nagy alegységében, az aktív centrum közelében, a Val67-et azonosították, mint potenciálisan jelentős $\mathrm{H}_{2}$ csatornaalkotó aminosav (Teixeira és mts., 2006). Feltételezésüket a V67A pontmutáció kialakításával in silico módon tesztelték, s igazolták, hogy az okozott mutáció hatással van a $\mathrm{H}_{2}$ aktív centrumba való jutására. Továbbá feltételezhetően ez a Val aminosav lehet a [NiFe] hidrogenázok katalitikus mechanizmusának, s egyben az $\mathrm{O}_{2}$, mint a katalitikus mechanizmus inhibítorának az aktív centrumba jutásának kontroll pontja is.

A hidrogenázok belsejében lévő $\mathrm{Ni}$ a molekuláris hidrogén szintézisének vagy hasításának helye, ahová a $\mathrm{H}_{2}$ hidrofób csatornákon jut be (Dole és mts., 1997). A hidrogén enzimatikus hasítása során keletkező elektronok és protonok, különböző útvonalakon keresztül érik el megfelelő biológiai akceptoraikat. A [NiFe] hidrogenázokban az elektronok az aktív centrumból a redox partnerhez a kis alegységben lévő vas-kén klaszterek láncolatán keresztül jutnak el (Volbeda és mts., 1995). A felszíni, disztális [4Fe4S] klaszter szokatlan módon, His(Cys) $)_{3}$ aminosavakon keresztül kapcsolódik a fehérje mátrixhoz. A His aminosavnak a FeS klaszter koordinálásában, és ezáltal a disztális klaszter felé irányuló, valamint az onnan kiinduló elektrontranszferben betöltött esszenciális szerepét a $D$. fructosovorans-ban irányított mutagenezis kísérletekkel létrehozott törzsek segítségével igazolták (Dementin és mts., 2006). 
Hasonló módszert használtak a középső (mediális) [3Fe4S] klaszter vizsgálatánál is. A [3Fe4S] klaszternek az intramolekuláris elektrontranszferben betöltött szerepét $D$. fructosovorans [NiFe] hidrogenázában tanulmányozták. Itt a Pro238 foglalja el annak a potenciális aminosavnak a helyét, mely a [4Fe4S] klaszterekhez képest a „hiányzó”, negyedik Fe koordinálását végezné. A középső FeS klasztert a fehérje mátrixhoz rögíző aminosavak ( $D$. fructosovorans-ban Pro238, Cys227, Cys245, Cys248) közül a Pro238-at ciszteinre cserélték, mivel a Desulfomicrobium baculatum [NiFeSe] hidrogenázban a középső vas-kén kockát négy cisztein aminosav koordinálja (Voordouw és mts., 1989). Ez a Pro238Cys mutáció nem befolyásolta jelentősen a [NiFe] aktív centrum és a két natív [4Fe4S] klaszter spektroszkópiai és redox tulajdonságait (Rousset és mts., 1998). Habár a mutáció következtében a mediális FeS klaszter potenciálja nagymértékben megváltozott, ez az enzim aktivitására nem volt igazán hatással. A szerzők ebböl arra következtettek, hogy feltehetően nem az elektrontranszfer a sebesség meghatározó lépés az enzimkatalízis során, valószínübb, hogy az aktivitást a protontranszfer korlátozza.

Számos elméleti, elsősorban a [NiFe] hidrogenázok struktúráinak elemzésén alapuló (Fdez Galvan és mts., 2008, Teixeira és mts., 2008) és néhány kísérletes kutatás (Dementin és mts., 2004) irányult korábban azon aminosavak feltérképezésére is, melyek a hidrogenázok katalitikus folyamatai során végbemenő protontranszferben vehetnek részt. Így sikerült feltárni, majd kísérletekkel is alátámasztani, hogy a [NiFe] hidrogenázok nagy alegységében a Glu25-nek (Desulfovibrio fructosovorans szerinti számozás) esszenciális szerepe van a $\mathrm{H}_{2}$ aktív centrumban történő hasítását követő protontranszferben (Dementin és mts., 2004). Azonban még mindig nagyon kevés kísérleti bizonyíték áll rendelkezésre arról, hogy milyen útvonalon/útvonalakon továbbítódnak a protonok a fehérjén belül. Ezen protonútvonalak feltérképezése, a transzportfolyamat mechanizmusának meghatározása elengedhetetlen a hidrogenázok müködésének megértéséhez. 


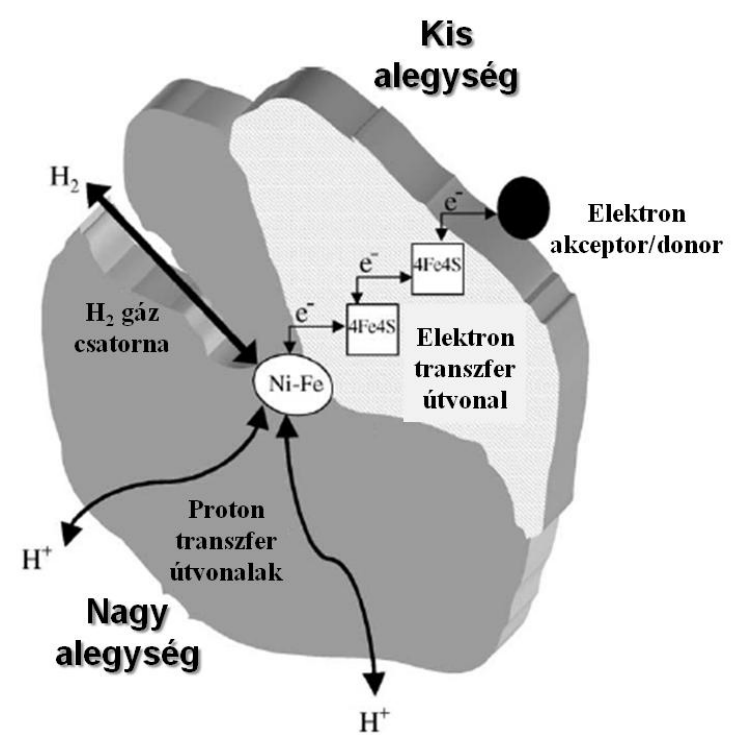

3. ábra: A [NiFe] hidrogenázok katalitikus reakcióinak sematikus ábrája. A kis alegységben, a könnyebb átláthatóság kedvéért csupán két FeS klaszter látható (de Lacey és mts., 2005).

\section{A proton kapcsolt elektrontranszfer jelentősége a biológiai rendszerekben}

A proton- és elektrontranszfer az enzimekben bonyolult szerkezeti motívumokon, ún. „csatornákon” keresztül valósul meg (3. ábra). A csatorna egyes tagjai közti távolság a két elemi részecske esetén eltérő. Az elektrontranszfer többnyire nagyobb távolságokat ölel át, ahol a transzfer útvonal tagjai, melyek egymáshoz kovalens kötésekkel kapcsolódnak, egymástól akár $12 \AA$-re is (Page és mts., 2003, Leys és mts., 2004) elhelyezkedhetnek. Elektrontranszfer végbemehet hidrogénhíd kötéseken keresztül is, de ekkor a folyamat körülbelül négyszer lassúbb (Reece és mts., 2009, Hammes-Schiffer és mts., 2010). Az elektron, miután elérte a fehérje felszínét (intramolekuláris elektrontranszfer) az enzim és a megfelelő elektronakceptor között helyeződik át (intermolekuláris elektrontranszfer). Az elektrontranszferrel egy időben lejátszódó protontranszfer során a protonok hidrogénhíd kötéseken, vagy protonálódásra képes csoportokból álló proton-vezető csatornán keresztül továbbítódnak. Mindez az elektrontranszferhez képest sokkal kisebb (kb. 2,5-3,5 $)$ távolságokon valósulhat meg az útvonal tagjai között.

Valójában azonban az elektrontranszfer során, a redox folyamatokból származó negatív töltés térbeli eloszlása változik, míg protontranszfer esetében a proton pozitív töltése 
az, ami áthelyeződik a fehérjében (Grotthuss mechanizmus). E két folyamat azonban folyamatosan hatással van egymásra még akkor is, ha az elektron és a proton töltése térben egymáshoz képest távol mozog (3. ábra), mivel az elektromos töltések mozgása egymáshoz csatolva van. Az egyik töltés vándorlása megváltoztatja a fehérje megfelelő részeinek töltés állapotát, és ezzel hatással lesz a másik töltés mozgására is. Ebből adódóan szokás a két összekapcsolódó folyamatot proton kapcsolt elektrontranszfernek (proton-coupled electron transfer, PCET) is nevezni.

A biológiai rendszerekben a PCET sokszoros elektron- és protontranszfer lépésekből áll, melyben a teljes folyamat reakciósebességét mindig a leglassúbb folyamat sebessége határozza meg. A proton és az elektron közös vagy egymást követő lépésekben történő átvitele nem minden esetben különíthető el, különösen a nagyon gyorsan végbemenő reakciókban, ahol a stabil intermedierek meghatározása nehézkes (Reece és mts., 2009, Hammes-Schiffer és mts., 2010). A folyamatok kísérletes vizsgálatakor azonban elöfordulhat, hogy csak az egyik folyamatot tudjuk detektálni, és mivel a két folyamat kapcsoltan megy végbe, információt szerezhetünk a másikról is. Ezt tudjuk kihasználni a hidrogenázok katalitikus aktivitásának vizsgálatakor is.

A szakirodalomból tudjuk, hogy a PCET kulcsfontosságú szerepet játszik számos redox folyamatban részt vevő fehérje müködésében, mint például a citokróm c oxidáz, a II-es fotoszintetikus rendszer elemei, a ribonukleotid reduktáz enzim vagy a metalloenzimek esetében, beleértve a hidrogenázokat is (Reece és mts., 2009, Hammes-Schiffer és mts., 2010). Így ez utóbbiak esetében, ha irányított mutagenezissel olyan strukturális változást idéznek elő a fehérjében, amely a hidrogenázok katalitikus folyamatai szempontjából fontos csatornák (3. ábra) egyikét módosítja, ezzel befolyásolni lehet más transzfer útvonalak működését is.

\section{A [NiFe] hidrogenázok hisztidin gazdag motívuma}

Az ismert aminosav szekvenciával rendelkező [NiFe] hidrogenázok nagy alegységeinek szekvencia-összehasonlítása során egy erősen konzervált, szimmetrikus

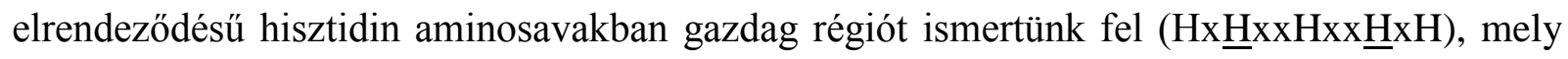


az eddig ismert legtöbb membránkötött hidrogenáz nagy alegységében megtalálható. A citoplazmatikus [NiFe] hidrogenázok esetében a második és a negyedik (aláhúzással jelölve) hisztidin helye konzervált. Ez a szekvenciarészlet már korábban is szerepelt a szakirodalomban, mint a [NiFe] hidrogenázok nagy alegységében általánosan megtalálható öt konzervált motívum egyikének része: (L1) RGxE, (L2) RxCGxCx3H, (L3) Hx6L

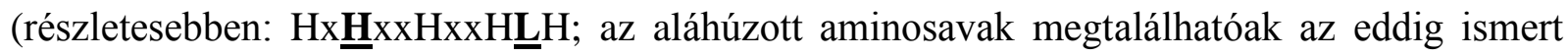
hidrogenázok mindegyikében), (L4) Gx4PRGx3H, és (L5) DPCx2Cx2H/R (Albracht 1994). $\mathrm{Ha}$ a [NiFe] hidrogenázok háromdimenziós szerkezetét tekintjük, ezek a hisztidinek a Ni atom proximális környezetében helyezkednek el (4. táblázat). Szerepükre vonatkozólag nem sok adat állt eddig rendelkezésre. Egyetlen kísérletes munkáról tudunk, melyben a Desulfovibrio desulfuricans Norway [NiFeSe] hidrogenázának belső hisztidin aminosavait (HxxHxxH) pentaaminruténium II-vel kémiailag módosították. A reakció következtében a hisztidinek imidazol gyürüjének N3-as nitrogénje a ruténiummal komplexbe kerül, így megszünik az imidazol gyürü további reakcióképessége. Az ily módon módosított hisztidineket tartalmazó enzim in vitro hidrogénfejlesztést nyomon követő reakciók eredményeiből azt a következtetést vonták le, hogy ezen aminosavak fontosak lehetnek az enzim katalitikus folyamata során (Mus-Veteau és mts., 1994). Burgdorf és munkatársai szintén vizsgálták az L3-as konzervált motívumot, és a $R$. eutropha szolubilis hidrogenázának HoxH alegységében pontmutációkat alkalmaztak, viszont kísérleteiket csak az L3-as motívum Leu118-as aminosavára korlátozták (Burgdorf és mts., 2002). Egy, a hidrogenázok struktúra-funkció közötti összefüggéseit összefoglaló tanulmányban a membránkötött [NiFe] hidrogenázok ismert kristályszerkezeteinek vizsgálatából egy Arg463, Asp528, His108 (ami az L3-as motívum középső His aminosavának felel meg), valamint Arg404 aminosavakat magába foglaló láncolatot írtak le, melyről feltételezték, protontranszfer útvonalként szerepelhet (FontecillaCamps és mts., 2007). Ebböl adódóan felmerült a kérdés, hogy az általunk megfigyelt Hisgazdag motívum és a fent említett protontranszfer útvonal között van-e összefüggés. Adódott tehát a feladat, hogy meghatározzuk a $\mathrm{HxHxxHxxHxH}$ motívum hidrogenáz enzimek müködésében betöltött funkcióját. 


\section{Célkitüzések}

Napjainkban több szulfát-redukáló baktérium, és egy nem szulfát-redukáló, fotoszintetizáló baktérium periplazmatikus [NiFe] hidrogenázának kristályszerkezete is ismert. Ezen szerkezetek tanulmányozása lehetővé tette számos, a hidrogenáz enzimekre jellemző strukturális elem és a hozzá kapcsolható funkció közötti összefüggés azonosítását. Továbbá összehasonlíthatóvá vált a különböző fajokból származó enzimek aktív centrumának felépítése, és az azt körülvevő fehérjekörnyezetnek az enzim aktivitására gyakorolt hatása is. Ezen kívül már az aktív hely és a fehérje felszíne közötti „szubmolekuláris” útvonalak nagy részét is feltérképezték, melyek részt vehetnek a hidrogén, proton, elektron, oxigén és CO transzportban.

Munkám során célul tüztem ki:

- Olyan, eddig még nem jellemzett szekvenciarészletek keresését, amelyek a [NiFe] hidrogenázokra általánosan jellemzőek, és meghatározott funkciókért lehetnek felelősek.

- A hidrogenázok nagy alegységében megfigyelt nagyon konzervált, hisztidinekben gazdag szekvenciamotívum részletes vizsgálatát annak kiderítésére, hogy ez a régió mely enzimtulajdonságok kialakulásáért felelős. Kísérleteimhez a T. roseopersicina HynSL hidrogenázát használtam modellként, mivel ez az enzim könnyen vizsgálható, expressziója anaerob körülmények között látszólag konstitutív.

- Az adott aminosavakban mutáns törzsek elkészítését irányított mutagenezissel.

- A HynL alegységében mutáns T. roseopersicina törzsekben annak tanulmányozását, hogy a mutáns aminosavsorrendü enzim aktivitása, sejten belüli mennyisége, elhelyezkedése hogyan változik.

- A szakirodalomból ismert, a D. gigas-ban leírt Arg463, Asp528, His108 és Arg404 aminosavakat magába foglaló alternatív protontranszfer útvonal és az általunk megfigyelt His-gazdag motívum közötti kapcsolat vizsgálatát.

- A [NiFe] hidrogenázokban előforduló egyéb alternatív protontranszfer útvonalak keresését és az útvonalak aminosavai szerepének igazolását kísérletes eredményekkel. 


\section{Anyagok és módszerek}

\section{Baktérium törzsek és plazmidok}

\section{Táblázat: Baktérium törzsek és plazmidok megnevezése, leírása}

\begin{tabular}{|c|c|c|}
\hline Törzsek & Genotípus & Referencia \\
\hline \multicolumn{3}{|l|}{ T. roseopersicina } \\
\hline BBS & vad típus & (Bogorov 1974) \\
\hline GB112131 & $\Delta$ hynSL, $\Delta$ hupSL, $\Delta$ hox $1 H$ törzs & $\begin{array}{l}\text { (Rakhely és mts., } \\
\text { 2004) }\end{array}$ \\
\hline $\begin{array}{l}\text { GB112131 + } \\
\text { pTHOE5M }\end{array}$ & $\begin{array}{l}\text { pTHOE } 5 \mathrm{M} \text { plazmid a } \Delta h y n S L, \Delta h u p S L, \\
\Delta h o x 1 H \text { törzsben }\end{array}$ & $\begin{array}{l}\text { B. D. Fodor, nem } \\
\text { közölt munka }\end{array}$ \\
\hline MH102A & pMH102A plazmid a GB112131 törzsben & Ez a munka \\
\hline MH104A & pMH104A plazmid a GB112131 törzsben & Ez a munka \\
\hline MH107A & pMH107A plazmid a GB112131 törzsben & Ez a munka \\
\hline MH110A & pMH110A plazmid a GB112131 törzsben & Ez a munka \\
\hline MH112A & pMH112A plazmid a GB112131 törzsben & Ez a munka \\
\hline MH102/104/107/110/112A & $\begin{array}{l}\text { pMH102/104/107/110/112A plazmid a } \\
\text { GB112131 törzsben }\end{array}$ & Ez a munka \\
\hline MH102/107/110/112A & $\begin{array}{l}\text { pMH102/107/110/112A plazmid a } \\
\text { GB112131 törzsben }\end{array}$ & Ez a munka \\
\hline MR487I & pMR487I plazmid a GB112131 törzsben & Ez a munka \\
\hline MD103L & pMD103L plazmid a GB112131 törzsben & Ez a munka \\
\hline MH104F & pMH104F plazmid a GB112131 törzsben & Ez a munka \\
\hline ME436I & pME436I plazmid a GB112131 törzsben & Ez a munka \\
\hline ME14Q & pME14Q plazmid a GB112131 törzsben & Ez a munka \\
\hline \multicolumn{3}{|l|}{ E. coli } \\
\hline S17-1( $\lambda$ pir $)$ & $\begin{array}{l}294 \text { (recA pro res mod) } \mathrm{Tp}^{\mathrm{r}}, \mathrm{Sm}^{\mathrm{r}} \text { (pRP4-2-Tc::Mu- } \\
\mathrm{Km}:: \operatorname{Tn} 7), \lambda \text { pir }\end{array}$ & $\begin{array}{l}\text { (Herrero és mts., } \\
1990)\end{array}$ \\
\hline XL1-Blue MRF' & $\begin{array}{l}\Delta(\text { mcrA }) 183, \Delta(\text { mcrCB-hsdSMR-mrr }) 173, \text { endA1, } \\
\text { supE44, thi-1, recAl, gyrA96, relA1 lac [F' proAB }\end{array}$ & Stratagene \\
\hline
\end{tabular}




\begin{tabular}{|c|c|c|}
\hline Vektorok & Genotípus & Referencia \\
\hline pBluescript SK (+) & ColE1 Amp ${ }^{r}$ & Stratagene \\
\hline pTHOE5M & hynS-isp1-isp2-hynL operon a pDSK509 vektorban & $\begin{array}{l}\text { B. D. Fodor, nem } \\
\text { közölt munka }\end{array}$ \\
\hline pBtHynLApa & $\begin{array}{l}\text { pBluescriptSK-ban a } 3273 \text { bp ApaI fragment } \\
\text { pTHOE5M-ből }\end{array}$ & Ez a munka \\
\hline $\mathrm{pBtH} 102 \mathrm{~A}$ & pBtHynLApa 102-es His mutálva Ala-ra & Ez a munka \\
\hline pBtH104A & pBtHynLApa 104-es His mutálva Ala-ra & Ez a munka \\
\hline $\mathrm{pBtH} 107 \mathrm{~A}$ & pBtHynLApa 107-es His mutálva Ala-ra & Ez a munka \\
\hline pBtH110A & pBtHynLApa 110-es His mutálva Ala-ra & Ez a munka \\
\hline pBtH112A & pBtHynLApa 112-es His mutálva Ala-ra & Ez a munka \\
\hline pBtH102/104/107/110/112A & $\begin{array}{l}\text { pBtHynLApa 102, 104, 107, } 110 \text { és 112-es His-ek } \\
\text { mutálva Ala-ra }\end{array}$ & Ez a munka \\
\hline pBtH102/107/110/112A & $\begin{array}{l}\text { pBtHynLApa 102, 107, } 110 \text { és } 112 \text {-es His-ek } \\
\text { mutálva Ala-ra }\end{array}$ & Ez a munka \\
\hline pBtR487I & pBtHynLApa 487-es Arg mutálva Ile-ra & Ez a munka \\
\hline $\mathrm{pBtD} 103 \mathrm{~A}$ & pBtHynLApa 103-as Asp mutálva Leu-ra & Ez a munka \\
\hline $\mathrm{pBtH} 104 \mathrm{~F}$ & pBtHynLApa 104-es His mutálva Phe-ra & Ez a munka \\
\hline $\mathrm{pBtE} 436 \mathrm{I}$ & pBtHynLApa 436-os Glu mutálva Ile-ra & Ez a munka \\
\hline pBtE14Q & pBtHynLApa 14-es Glu mutálva Gln-ra & Ez a munka \\
\hline pMH102A & $\begin{array}{l}\text { H102A mutációt hordozó hynL gén az ApaI } \\
\text { emésztett pTHOE5M vektorban }\end{array}$ & Ez a munka \\
\hline pMH104A & $\begin{array}{l}\text { H104A mutációt hordozó hynL gén az ApaI } \\
\text { emésztett pTHOE5M vektorban }\end{array}$ & Ez a munka \\
\hline
\end{tabular}




\begin{tabular}{|c|c|c|}
\hline pMH107A & $\begin{array}{l}\text { H107A mutációt hordozó hynL gén az ApaI } \\
\text { emésztett pTHOE5M vektorban }\end{array}$ & Ez a munka \\
\hline pMH110A & $\begin{array}{l}\text { H110A mutációt hordozó hynL gén az ApaI } \\
\text { emésztett pTHOE5M vektorban }\end{array}$ & Ez a munka \\
\hline pMH112A & $\begin{array}{l}\text { H112A mutációt hordozó hynL gén az ApaI } \\
\text { emésztett pTHOE5M vektorban }\end{array}$ & Ez a munka \\
\hline pM102/104/107/110/112A & $\begin{array}{l}\text { H102/104/107/110/112A mutációt hordozó } \\
\text { hynL gén az ApaI emésztett pTHOE5M vektorban }\end{array}$ & Ez a munka \\
\hline pMH102/107/110/112A & $\begin{array}{l}\text { H102/107/110/112A mutációt hordozó hynL gén az } \\
\text { ApaI emésztett pTHOE5M vektorban }\end{array}$ & Ez a munka \\
\hline pMR487I & $\begin{array}{l}\text { R487I mutációt hordozó hynL gén az ApaI } \\
\text { emésztett pTHOE } 5 \mathrm{M} \text { vektorban }\end{array}$ & Ez a munka \\
\hline pMD103L & $\begin{array}{l}\text { D103L mutációt hordozó hynL gén az ApaI } \\
\text { emésztett pTHOE } 5 \mathrm{M} \text { vektorban }\end{array}$ & Ez a munka \\
\hline pMH104F & $\begin{array}{l}\text { H104F mutációt hordozó Mutáns hynL gén az ApaI } \\
\text { emésztett pTHOE5M vektorban }\end{array}$ & Ez a munka \\
\hline pME436I & $\begin{array}{l}\text { E436I mutációt hordozó hynL gén az ApaI } \\
\text { emésztett pTHOE5M vektorban }\end{array}$ & Ez a munka \\
\hline pME14Q & $\begin{array}{l}\text { E14Q mutációt hordozó hynL gén az ApaI } \\
\text { emésztett pTHOE5M vektorban }\end{array}$ & Ez a munka \\
\hline
\end{tabular}

\section{Baktériumok tenyésztése}

A T. roseopersicina BBS törzsét $25-28^{\circ} \mathrm{C}$-on folyamatos megvilágítás mellett, teletöltött csiszolt dugós üvegekben, Pfennig féle (PC) tápoldatban növesztettem 5-6 napig (1 liter vízben $20 \mathrm{~g} \mathrm{NaCl}, 1 \mathrm{~g} \mathrm{KH}_{2} \mathrm{PO}_{4}, 1 \mathrm{~g} \mathrm{MgCl}_{2}, 1 \mathrm{~g} \mathrm{KCl}, 1 \mathrm{~g} \mathrm{NH}$ Cl, $2 \mathrm{~g} \mathrm{NaHCO} 3,4 \mathrm{~g}$ $\mathrm{Na}_{2} \mathrm{~S}_{2} \mathrm{O}_{3}, 200 \mu \mathrm{B}_{12}$ vitamin $(100 \mu \mathrm{g} / \mathrm{ml}), 1 \mathrm{ml} \mathrm{Fe-EDTA}(3,3 \mathrm{~g} / \mathrm{l}), 1 \mathrm{ml}$ mikroelem oldat. Mikroelem oldat: $2975 \mathrm{mg} \mathrm{Na}$-EDTA, $300 \mathrm{mg} \mathrm{H}_{3} \mathrm{BO}_{4}, 200 \mathrm{mg} \mathrm{CaCl}_{2} \cdot 6 \mathrm{H}_{2} \mathrm{O}, 100 \mathrm{mg}$ $\mathrm{ZnSO}_{4} \cdot 7 \mathrm{H}_{2} \mathrm{O}, 30 \mathrm{mg} \mathrm{MnCl}_{2} \cdot 4 \mathrm{H}_{2} \mathrm{O}, 30 \mathrm{mg} \mathrm{Na} 2 \mathrm{MoO}_{4} \cdot 2 \mathrm{H}_{2} \mathrm{O}, 20 \mathrm{mg} \mathrm{NiCl} \cdot 6 \mathrm{H}_{2} \mathrm{O}, 10 \mathrm{mg}$ $\mathrm{CuCl}_{2} \cdot 2 \mathrm{H}_{2} \mathrm{O}, 1000 \mathrm{ml}$ vízben) (Pfennig és mts., 1983). Nitrogén kötő körülmények biztosítása érdekében $\mathrm{NH}_{4} \mathrm{Cl}$-t nem tettem a tápoldatba. A lemezöntéshez használt $\mathrm{PC}$ tápoldatot (a szokásostól eltérő mennyiségek: $\left.18 \mathrm{~g} / 1 \mathrm{NaCl}, 2 \mathrm{~g} / 1 \mathrm{Na}_{2} \mathrm{~S}_{2} \mathrm{O}_{3}\right) 2 \mathrm{~g} / \mathrm{l} \mathrm{Na}$-acetáttal és Phytagellel (Sigma) (7 g/liter) egészítettem ki. A sejteket ezekre szélesztve az Oxoid AnareoGen $\left(\mathrm{N}_{2}\right.$, $\mathrm{CO}_{2}$ ) rendszereivel anaerobizált dobozokban 14 napig fényen inkubáltam. Az E. coli sejteket $37^{\circ} \mathrm{C}$-on LB tápoldatban (1 literre: $5 \mathrm{~g} \mathrm{NaCl}, 5 \mathrm{~g}$ élesztő kivonat, $10 \mathrm{~g}$ Bacto Triptone, $\mathrm{pH}=7$ ) 
vagy $\mathrm{LB}$ táplemezen $(\mathrm{LB}+1,5 \%$ agar) tartottam fenn. Az alkalmazott antibiotikum koncentrációk T. roseopersicina-ra folyadékban: kanamicin $25 \mu \mathrm{g} / \mathrm{ml}$, eritromicin $50 \mu \mathrm{g} / \mathrm{ml}$, sztreptomicin $25 \mu \mathrm{g} / \mathrm{ml}$, gentamicin $25 \mu \mathrm{g} / \mathrm{ml}$; lemezen: kanamicin $25 \mu \mathrm{g} / \mathrm{ml}$; E. coli-ra lemezen és folyadékban: kanamicin $25 \mu \mathrm{g} / \mathrm{ml}$, ampicillin $100 \mu \mathrm{g} / \mathrm{ml}$, tetraciklin $15 \mu \mathrm{g} / \mathrm{ml}$.

\section{Konjugáció}

A T. roseopersicina-t a konjugációhoz $28^{\circ} \mathrm{C}$-on $\mathrm{OD}_{650}=1,8$-ig, az E. coli-t $37^{\circ} \mathrm{C}$-on a megfelelő antibiotikum jelenlétében $\mathrm{OD}_{600}=0,6$-ig növesztettem, majd centrifugálás után, sóoldatban (20 g/l NaCl, $\left.1 \mathrm{~g} / 1 \mathrm{KH}_{2} \mathrm{PO}_{4}, 1 \mathrm{~g} / 1 \mathrm{MgCl}_{2}, 1 \mathrm{~g} / \mathrm{K} \mathrm{KCl}\right)$ felvéve összekevertem. Az így kapott sejteket $2 \mathrm{~g} / 1$ Nutrient Broth-ot és $2 \mathrm{~g} / \mathrm{l} \mathrm{Na}$-acetátot tartalmazó, 1,5\% agarral szilárdított Pfennig-féle (Pfennig és mts., 1983) táptalajra cseppentettem. Csak a donor, és csak a recipiens törzseket tartalmazó kontroll kísérleteket is elvégeztem. Egy éjszakán át fényen, levegőn, $28^{\circ} \mathrm{C}$-on inkubáltam ezeket a lemezeket. Másnap, hígítási sort készítve szelektív lemezre szélesztettem a mindkét baktériumot tartalmazó, valamint a két kontroll lemezröl is. A lemezeket anaerob körülmények között, fényen 14 napig $28^{\circ} \mathrm{C}$-on inkubáltam.

\section{DNS manipulációs munkák}

\subsection{Plazmid DNS izolálása E. coli-ból}

Plazmid izoláláshoz $5 \mathrm{ml}$ antibiotikum tartalmú LB tápoldatba oltottam le egy telepet a meghatározott baktérium törzsből. A sejteket egész éjszakán át $37^{\circ} \mathrm{C}$-on rázatva növesztettem. Másnap az így felnőtt tenyészetből a Sigma plazmid izoláló rendszerével tisztítottam DNS-t (Sigma Kat. szám: PLN350). A tenyészetet 1,5 ml-es centrifugacsőben centrifugáltam (13000 rpm 5 perc). A sejteket $200 \mu \mathrm{l}$ Puffer P1-ben $(50 \mathrm{mM}$ TRIS/HCl, pH = 8; $10 \mathrm{mM}$ EDTA; 100mg RNáz A) szuszpendáltam fel, majd a felszuszpendált sejtekre $200 \mu$ l Puffer P2-t (200 $\mathrm{mM} \mathrm{NaOH} ; 1 \%$ SDS) mértem, és keverés után az elegyet 5 percig inkubáltam szobahőmérsékleten. Ezt követően $350 \mu \mathrm{l}$ Puffer P3-t (3M Kálium-acetát, $\mathrm{pH}=5,5$ ) adtam a feltárt sejtekhez, melyeket ezután 10 percig jégen tartottam, majd centrifugáltam (13200 rpm, 10 perc, $\left.4^{\circ} \mathrm{C}\right)$. A DNS tisztító oszlopra először $500 \mu 1$ előkészítő oldatot vittem fel, centrifugáltam, majd pedig a sejtlizátumot mértem rá az oszlopra. Centrifugálás után a nem specifikusan kötődő anyagokat $750 \mu$ mosó pufferrel lemostam, majd a teljesen kiszárított 
oszlopra $50 \mu \mathrm{l}$ desztillált vizet tettem. Pár perc várakozás után a tisztított DNS-t tiszta Eppendorf csőbe centrifugáltam.

\subsection{Agaróz gélelektroforézis}

Az analitikai és preparatív célokból végzett gélelektroforézisekhez 1,0\%-os, $0,1 \mu \mathrm{g} / \mathrm{ml}$ etídium-bromidot tartalmazó agaróz gélt használtam 1xTAE pufferben (4 mM TRIS-acetát, 1 mM EDTA pH = 8,0), 70-90 V futtatási feszültséggel.

\subsection{Fragmentizolálás}

Preparatív agaróz gélelektroforézis után a gélből a kívánt DNS fragmentet steril pengével vágtam ki, és egy 1,5 ml-es centrifugacsőbe helyeztem. A DNS izolálását a gélből a Fermentas DNS extrakciós kit-jével (Kat. szám: K0513) végeztem. A kivágott, kb $200 \mu$ l-es géldarabhoz háromszoros mennyiségü $\mathrm{NaI}$ oldatot adtam és az agaróz oldódásáig $55^{\circ} \mathrm{C}$-on rázattam. $5 \mu \mathrm{l}$ szilikaport adtam az oldathoz és 5 percig $55^{\circ} \mathrm{C}$-on inkubáltam, pár percenként

felrázva. Egy perces fugálás (13000 rpm) után az üledéket átmostam $500 \mu$ mosó pufferrel, majd újabb 1 percig fugáltam 13000 rpm-en. A mosást még kétszer megismételtem, majd az utolsó fugálás után az üledéket szobahőmérsékleten szárítottam. Ezután a szilikaporra $20 \mu l$ desztillált vizet mértem és $55^{\circ} \mathrm{C}$-os termosztátban inkubáltam 10 percig. Legvégül a szuszpenziót addig centrifugáltam (13000 rpm-en), míg szilikapor mentes felülúszót nem kaptam. Az izolált DNS mintát a felhasználásig $-20^{\circ} \mathrm{C}$-on tároltam.

\subsection{Emésztés restrikciós enzimekkel}

A restrikciós emésztéseket Fermentas enzimekkel végeztem a gyártó cég puffer rendszerét használva.

\subsection{Alkalikus foszfatáz kezelés}

A Fermentas CIAP enzimet általában saját gyári pufferében használtam. 5 ' túlnyúló vég defoszforilálásához $37^{\circ} \mathrm{C}$-on 30 percen át inkubáltam a $\mathrm{DNS}$-t, majd 15 percig $85^{\circ} \mathrm{C}$-on való inkubálással állítottam le a reakciót (Sambrook és mts., 1989). 


\subsection{Ligálás}

A ligálandó DNS fragmentumot kb. 2-10-szeres feleslegben adtam a vektorhoz. Legtöbb esetben 0,5-2U Fermentas T4 DNS ligáz enzimet alkalmaztam Fermentas T4 DNS ligáz pufferben, $18-20^{\circ} \mathrm{C}$-on egy éjszakán át végezve a reakciót.

\section{E. coli kompetens sejt készítése}

Az XL1-Blue MRF' és S17-1 lambda pir sejteket $50 \mathrm{ml}$ SOB tápoldatban $(1000 \mathrm{ml}$ tápoldat: $20 \mathrm{~g}$ tripton, $5 \mathrm{~g}$ élesztő kivonat, $0,5 \mathrm{~g} \mathrm{NaCl}$ ) $\mathrm{OD}_{600}=0,4-0,6-i g$ növesztettem $22^{\circ} \mathrm{C}$ on, ezt követően a kultúrákat 10 percig jégen hütöttem, majd $2500 \mathrm{~g}$-n, $4^{\circ} \mathrm{C}$-on 10 percig centrifugáltam. Az összegyült sejteket jégen tartva $16 \mathrm{ml}$ TB pufferben $(250 \mathrm{ml}$ puffer: $10 \mathrm{mM}$ PIPES, $15 \mathrm{mM} \mathrm{CaCl} 2,250 \mathrm{mM} \mathrm{KCl}, 55 \mathrm{mM} \mathrm{MnCl}_{2}, \mathrm{pH}=6,7$ ) felszuszpendáltam, $\mathrm{s}$ újra 2500 g-n, $4^{\circ} \mathrm{C}$-on 10 percig centrifugáltam. A sejteket $4 \mathrm{ml}$ TB pufferben felszuszpendáltam, $300 \mu$ DMSO-t adtam a sejtszuszpenzióhoz, amit ezután 10 percig jégen inkubáltam. Ezt követően $100 \mu$ l-enként, elöre lehütött Eppendorf csövekbe szétosztva, folyékony $\mathrm{N}_{2}$-ben fagyasztottam le a kompetens sejteket, majd $-80^{\circ} \mathrm{C}$-on tároltam őket. (Inoue és mts., 1990).

\section{E. coli kémiai transzformálása}

Az eljárás során a transzformálandó DNS-t $100 \mu$, jégen felolvasztott $E$. coli kompetens sejthez adtam, melyet ezután 30 percig jégen tartottam. A hősokkot $\left(42^{\circ} \mathrm{C}, 40 \mathrm{mp}\right)$ követően a sejtekhez $900 \mu \mathrm{l}$ SOB-ot adtam, 1 órát $37^{\circ} \mathrm{C}$-on rázattam, végül a megfelelö antibiotikummal kiegészített LB lemezre szélesztettem.

\section{Polimeráz láncreakció (PCR)}

A reakciókat leggyakrabban Hybaid PCRExpress típusú készülékben végeztem. Az alábbi koncentrációjú reagensekből a végtérfogat 1/10 részét adtam a reakcióhoz: primerek $10 \mathrm{pmol} / \mu \mathrm{l}$, dNTP $2 \mathrm{mM}, 10 \times$ DyNAzyme puffer (Finnzymes). Templátként $(2 \mu \mathrm{l}) 50 \times$ hígított vektor DNS-t, illetve $E$. coli sejteken végzett kolónia PCR esetén $2 \mu 1$ sejtszuszpenziót (1 kolóniát $20 \mu \mathrm{l}$ vízben felszuszpendáltam) használtam. 0,5 $\mu \mathrm{l}$ DyNAzyme (Finnzymes) enzimet adtam $20 \mu$ reakcióelegybe. 
Azokban az esetekben, amikor szükség volt olyan DNS polimerázra, amely megbízhatóbb átírási aktivitással rendelkezik, Pfu (Fermentas) vagy Phusion (Finnzymes) enzimeket használtam. Általában 30-35 ciklusból állt egy program. Egy tipikus programciklus során a denaturáció 1 percig tartott $95^{\circ} \mathrm{C}$-on, a primer-templát hibridizációja $50-55^{\circ} \mathrm{C}$-on történt szintén 1 percig, majd ezt követően az elongáció $72^{\circ} \mathrm{C}$ hömérsékleten a felsokszorozni kívánt DNS hosszának megfelelő ideig tartott. A reakciót 5 percig tartó $72^{\circ} \mathrm{C}$-os termosztálással fejeztem be. Phusion polimeráz használatakor a program a következőképpen módosult: denaturáció: 30 másodperc $98^{\circ} \mathrm{C}$, hibridizáció: 30 másodperc $50-70^{\circ} \mathrm{C}, 20-30$ másodperc/kb elongáció $72^{\circ} \mathrm{C}$-on. Ezen lépéseket általában 30× ismételtem, majd a záróciklus $1 \times 5$ perc $72^{\circ} \mathrm{C}$-on történt.

\section{Nukleotid sorrend meghatározás}

A DNS szekvencia meghatározások automata szekvenálással készültek specifikus primer oligonukleotidok felhasználásával.

\section{Irányított mutagenezis}

A mutagenezishez a mutagenizálandó fragmentet pBluescript SK+ vektorba építettem, majd a Stratagene QuikChange XL kit-et (www.stratagene.com) használtam a mutáns klónok létrehozásához. Az $50 \mu \mathrm{l}$ végtérfogatú reakcióelegy a következő komponenseket tartalmazta: 20 ng templát DNS, $200 \mu \mathrm{M}$ dNTP-t, 10× PfuUltra puffert, valamint a megfelelő mutációt hordozó primer párok tagjaiból 125-125 ng-ot. A PCR-eket 2,5 U PfuUltra HF DNS polimerázzal végeztem, a következő program alapján: $30 \mathrm{mp} 95^{\circ} \mathrm{C}$-os kezdeti denaturációt követöen a 30 másodperc $95^{\circ} \mathrm{C}, 1$ perc $55^{\circ} \mathrm{C}, 6$ perc $72^{\circ} \mathrm{C}$ lépéseket 16 -szor ismételtettem meg. A PCR-ek termékét a reakcióelegyekhez adott $10 \mathrm{U} / \mu 1$ DpnI enzimmel emésztettem 1 órán át $37^{\circ} \mathrm{C}$-on, ezt követően E. coli XL1-Blue MRF' törzsbe transzformáltam. A mutagenezishez használt oligonukleotidokat a 2-es táblázat tartalmazza. A mutánsok részletes leírását lásd az Eredmények címü fejezetben. 
2. Táblázat: A helyspecifikus mutagenezishez használt oligonukleotidok. A mutáció eredményeként megjelenő aminosavakat kódoló tripletek félkövér betütípussal és aláhúzással vannak jelölve.

\section{Mutagenezishez használt oligonukleotidok}

OH102AF 5'-GATCAGCTCGCAGTTCGTGGCAGATCATGTGATGCACTTCTAT-3'

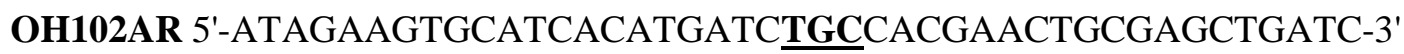

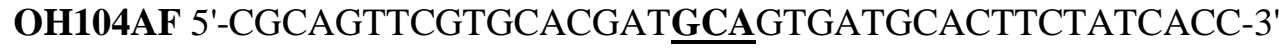

OH104AR 5'-GGTGATAGAAGTGCATCACTGCATCGTGCACGAACTGCG-3'

OH107AF 5'-GTGCACGATCATGTGATGGCATTCTATCACCTGCACGCG-3'

OH107AR 5'-CGCGTGCAGGTGATAGAATGCCATCACATGATCGTGCAC-3'

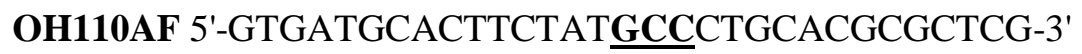

OH110AR 5'-CGAGCGCGTGCAGGGCATAGAAGTGCATCAC-3'

OH112AF 5'-CACTTCTATCACCTGGCCGCGCTCGACTGGG-3'

OH112AR 5'-CCCAGTCGAGCGCGGCCAGGTGATAGAAGTG-3'

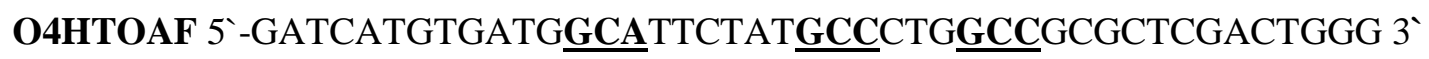

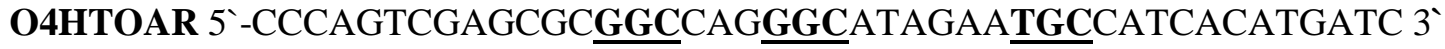

O5HTOAF 5 -

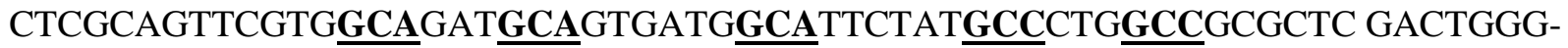
3

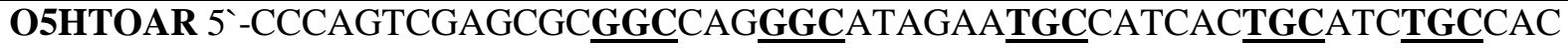
GAACTGCGAG-3

R487IF 5'-GTTACATGGAGGCCCCG서CGGCGCGCTCGGTCACTGG-3'

R487IR 5'-CCAGTGACCGAGCGCGCC

D103LF 5'-AGCTCGCAGTTCGTGCACETGCATGTGATGCACTTC-3'

D103LR 5'-GAAGTGCATCACATGCAGGTGCACGAACTGCGAGCT-3'

H104FF 5'-CGCAGTTCGTGCACGATTTCGTGATGCACTTCTATC-3'

H104FR 5'-GATAGAAGTGCATCACGAAATCGTGCACGAACTGCG-3'

E436IF 5'-GCGGCCCGGACCTTGATCACGAAGATCCTGACC-3'

E436IR 5'-GGTCAGGATCTTCGT

E14QF 5'-ATCCCGTCACCCGTATC

E14QR 5'-CGATGCGCAGATGGCCㅌGGATACGGGTGACGGGAT-3' 


\section{Membrán és szolubilis sejtfrakciók izolálása $T$. roseopersicina-ban}

\subsection{Sejtek feltárása szonikálással}

A $60 \mathrm{ml}, 5 \mu \mathrm{M} \mathrm{NiCl}_{2}$ tartalmú Pfennig féle tápoldatban, Hypo Vial üvegekben felnőtt sejteket 7000 g-n centrifugáltam, $4^{\circ} \mathrm{C}$-on, 10 percig, ezt követően $1 \mathrm{ml} 20 \mathrm{mM}$ kálium-foszfát pufferben ( $\mathrm{pH}=7,0)$ szuszpendáltam fel őket. A sejteket szonikálással tártam fel (Bandelin Sonopuls (Berlin, Germany) HD3100 ultrasonic homogenizer; 85\%-os amplitúdó, 6 szonikálási ciklus, 1 ciklus időtartama: 15 másodperc). A szonikálás utáni szuszpenziót 10000 g-n centrifugáltam $4^{\circ} \mathrm{C}$-on, 10 percig. Az Eppendorf cső alján összegyült „,csapadékot”, amely a fel nem tárt sejteket és a sejtekből kiszabaduló kénkristályokat tartalmazza, elválasztottam a felülúszótól (sejtextraktum), és a felülúszót ezután ultracentrifuga csövekbe pipettáztam át.

\subsection{Membrán és szolubilis frakció elválasztása ultracentrifugával}

A sejttörmeléktől elválasztott mintát (sejtextraktumot) Sorvall WX Ultra Series 90 típusú ultracentrifugával (paraméterek: T-1270 típusú rotor; $100000 \mathrm{~g}, 4^{\circ} \mathrm{C}, 1,5$ óra) centrifugáltam. Az ezt követően a kialakult felülúszó frakcióból 1,5 ml-t üvegpipettával átmértem 1,5 ml-es Eppendorf csövekbe (ez a szolubilis frakció), a kiülepedett membrán frakciót pedig $1 \mathrm{ml} 20 \mathrm{mM}$ kálium-foszfát pufferben $(\mathrm{pH}=7,0)$ szuszpendáltam fel. A mintákat $-20^{\circ} \mathrm{C}$-on tároltam.

\section{Hidrogenáz aktivitás mérési módszerek}

A különböző mutáns törzsekből származó hidrogenáz enzimek aktivitását in vivo és in vitro körülmények között is vizsgáltam. Minden esetben a GB112131 törzs (4hoxH, $4 h u p S L$, LhynS-isp1-isp2-hynL) volt a negatív, míg a GB112131+pTHOE5M törzs (4hoxH, 4 hupSL, ShynS-isp1-isp2-hynL törzs, melyben a vad típusú hynSL enzim a pTHOE5M vektorról expresszálódik) pedig a pozitív kontroll.

\subsection{In vivo hidrogéntermelés mérése gázkromatográffal}

A baktérium törzseket $60 \mathrm{ml}, 5 \mu \mathrm{M} \mathrm{NiCl}_{2}$ tartalmú Pfennig féle tápoldatban, $100 \mathrm{ml}$-es Hypo Vial üvegekbe oltottam le, nitrogén gázzal anaerobizáltam a lezárt üvegeket, majd 6 
napos növesztést követően a gáztérből $200 \mu 1$ mintát vettem Hamilton fecskendővel és gázkromatográfba fecskendeztem. A baktérium törzseket tartalmazó üvegek légteréböl vett minták $\mathrm{H}_{2}$ tartalmát hővezetöképességi detektorral mértem (Agilent 6890, MolSieve 5 kolonna, TCD detektor).

Az egyes törzsek in vivo hidrogenáz aktivitás eredményeit az egyes sejtkultúrákra meghatározott optikai denzitás (OD) értékekkel normalizáltam.

\subsection{In vitro hidrogéntermelés mérése}

A mérésekhez használt mintát a fent részletezett módon, a $60 \mathrm{ml}$ T. roseopersicina kultúrából készített sejtextraktum jelentette. A minta összfehérjetartalmát Micro-Lowry módszerrel határoztam meg (Yeang és mts., 1998), majd a mérésekhez ebből 0,1 mg/ml összfehérjetartalomnak megfelelő mennyiségü mintát készítettem. A reakcióelegyet $5 \mathrm{ml}$-es Hypo Vial üvegben mértem össze, a minta térfogatát 2 ml-re egészítettem ki $20 \mathrm{mM}$ káliumfoszfát pufferrel ( $\mathrm{pH}=7,0)$, majd $40 \mu \mathrm{l} 40 \mathrm{mM}$ metil-viologént adtam hozzá. A Hypo Vial üvegeket lezárásuk után nitrogénnel anaerobizáltam, majd $100 \mu 150 \mathrm{mg} / \mathrm{ml}$ koncentrációjú nátrium-ditionit oldatot fecskendeztem be, ezzel redukálva el az összes metil-viologént, ami így elektrondonorként müködött. A mintákat $60^{\circ} \mathrm{C}$-on inkubáltam, majd 1 óra elteltével gázkromatográffal mértem a termelt hidrogén mennyiségét.

\subsection{In vitro hidrogén felvevö aktivitás detektálása spektrofotométerrel}

A spektrofotometriás vizsgálatokhoz használt küvettákba az egyes törzsekből származó sejtextraktum megfelelő mennyiségét $20 \mathrm{mM}$ kálium-foszfát pufferrel $(\mathrm{pH}=7,0)$ egészítettem ki 2 ml-re, majd $40 \mu 140 \mathrm{mM}$ benzil-viologén oldatot adtam a reakcióelegyhez. A küvetták lezárása után a mintákat 5 percig nitrogén gázzal, majd újabb 5 percig $100 \%$ hidrogén gázzal fúvattam át, majd a spektrofotométerben $60^{\circ} \mathrm{C}$-on inkubáltam őket a kék szín megjelenéséig, amely a benzil-viologén redukálódását jelenti. A reakcióban a színintenzitás változás sebessége arányos a mutáns aminosavsorrendü és a kontroll enzimek hidrogén felvevő aktivitásával, melyet így a használt redox festék elnyelési hullámhosszán, 600 nm-en lehetett nyomon követni. 


\section{Fehérje mennyiségi meghatározása Lowry módszerrel (Micro-Lowry módszer)}

A fehérjéket TCA-val való kicsapás után $800 \mu 1$ 0,25 M NaOH-ban oldottam fel, majd a $\mathrm{C}$ reagensből (C reagens: 6\%-os nátrium-karbonát és 15\%-os réz-szulfát, 3\% nátrium-citrát keverék 50:1 arányú elegye) 300 ml-t adtam a fehérje oldathoz és keverés után 15 percig szobahőmérsékleten tartottam. Ezután $100 \mathrm{ml}$ 72\%-os Folin reagenst adtam a fehérje oldathoz, majd 30 perc inkubálás után 750 nm-en mértem az oldat fényelnyelést fotométerrel (BIORAD SmartSpec 3000). Az ismeretlen minták koncentrációját borjú szérum albuminból készített kalibrációs egyenes segítségével határoztam meg (Yeang és mts., 1998).

\section{Denaturáló poliakrilamid gélelektroforézis (SDS-PAGE)}

A fehérjeminták analíziséhez 1,5 mm vastag 10\%-os denaturáló poliakrilamid gélt használtam (Sambrook és mts., 1989), amely egy szeparáló, és egy felső, tömörítő gélből állt.

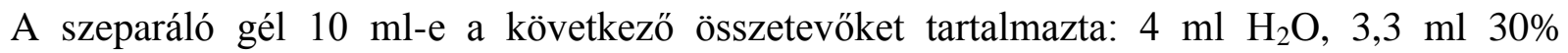
akrilamid (akrilamid-biszakrilamid: 29:1), 2,5 ml 1,5 M-os TRIS puffer ( $\mathrm{pH}=8,8), 0,1 \mathrm{ml}$ $10 \%$ SDS, 0,1 $\mathrm{ml} \mathrm{10 \%}$ APS és $4 \mu \mathrm{l}$ TEMED. A felső, tömörítő gélt az alábbiak szerint készítettem el: 0,5 ml 30\% akrilamid, $380 \mu \mathrm{l}$ 1,5 M TRIS (pH =6,8), $30 \mu 1$ 10\% SDS, $30 \mu 1$ 10\% APS, $3 \mu \mathrm{T}$ TEMED és végül desztillált vízzel 3 ml-re egészítettem ki az elegyet. A mintákat $1 \times$ SDS-felvivő pufferben 10 percig $95^{\circ} \mathrm{C}$-on inkubáltam. A poliakrilamid gélek futtatása TGS (TRIS-glicin-EDTA) pufferben (25 mM TRIS, $192 \mathrm{mM}$ glicin, 0,1\% SDS pH = 8,3) történt 120V-on, 2 órán keresztül.

A 2-szeres felvivő puffer a következőket tartalmazta: $100 \mathrm{mM}$ TRIS/HCl $(\mathrm{pH}=6,8)$, 200 mM DTT, 4\% SDS, 0,2\% brómfenolkék, 20\% glicerin (Ausubel 1995).

\section{Western hibridizáció}

A kísérletekhez a korábbiakban már említett módon előállított sejtextraktumokat használta, melyek összfehérje tartalmának meghatározása a fentiekben részletezett módon történt. Az egyszeres hisztidin-mutánsokkal végzett Western hibridizációs kísérletekben $50 \mu$ g-nyi összfehérjét, míg a protoncsatorna vizsgálatakor használt mutáns és kontroll törzsek esetében 25 g-nyi összfehérjét tartalmazó mintákat használtam. 
Az egyes mintákban lévő fehérje sávokat 10\% SDS-PAGE-sel választottam el (futtatási körülmények: 3 óra, $120 \mathrm{~V}$ ), majd nitrocellulóz membránra (Amersham $^{\mathrm{TM}}$ Hybond $^{\mathrm{TM}}$-ECL) blottoltam Trans-Blot ${ }^{\circledR}$ SD Semi-Dry Electrophorethic Transfer Cell (BioRad) készülék segítségével (45 perc, $25 \mathrm{mV}$; 11 transzfer puffer: 48 mM TRIS, 39 mM glicin, 20\% metanol, 1,3 mM SDS; pH =9,2). A membránt ezután 1 órán át blokkoló oldatban tartottam, ezzel megakadályozva a nem-specifikus fehérjék kötődését (blokkoló oldat: 5\%-os alacsony zsírtartalmú tejpor feloldva TBST pufferben (500 ml NaCl, 0,05\% Tween 20, $10 \mathrm{mM}$ TRIS-HCl, pH = 7,5). Elsődleges ellenanyagként Anti-HupL ellenanyagot használtam 1:10000-es hígításban (az elsődleges ellenanyagot Dr. Qing Xu, JCVI, USA bocsátotta a rendelkezésünkre). A másodlagos ellenanyagot (goat anti rabbit $\mathrm{HRP} \mathrm{H}+\mathrm{L}$ ) 1:5000-es hígításban alkalmaztam. A detektálás során a membránt 1 percig inkubáltam az enhancer és peroxid 1-1 ml-es elegyével (Pierce, SuperSignal West Pico Rabbit IgG Detection Kit), majd a kemilumineszcens jelet autoradiográfiásan detektáltam (GE Healthcare Limited, Amersham Hyperfilm ECC).

\section{Bioinformatika}

\subsection{A [NiFe] hidrogenázok szekvencia összehasonlítása}

Az egyes hidrogenáz fehérjék nagy alegységeinek szekvenciáját BLASTP (http://npsapbil.ibcp.fr/cgi-bin/npsa_automat.pl?page=npsa_blast.html) és CLUSTAL X szoftverek segítségével hasonlítottam össze.

\subsection{A $\quad$ [NiFe] hidrogenázok szerkezet vizsgálata}

A T. roseopersicina Hyn hidrogenázának háromdimenziós szerkezetét ez idáig nem sikerült kísérletes módszerekkel meghatározni, viszont korábbi munkák nagyarányú szekvencia homológiát állapítottak meg a Desulfovibrio fajok hidrogenáz enzimeivel (Szilagyi és mts., 2002). A Desulfovibrio vulgaris Miyazaki F. redukált állapotú [NiFe] hidrogenázáról nagy felbontású (1,50 Å) röntgenszerkezet állt rendelkezésre (PDB ID: 1WUL (Ogata és mts., 2005)), melyet modellként felhasználva végeztük el a T. roseopersicina Hyn hidrogenáz nagy alegységének szerkezet vizsgálatát. Ez a modell megfelelőnek bizonyult, mivel nem kizárólag a hidrogenáz atomjainak térbeli elrendeződésére vonatkozó információkat, hanem a szerkezeti 
vizek oxigénjeinek pozícióit is tartalmazza. A röntgenszerkezetek sajátossága, hogy a hidrogénatomok koordinátáit viszonylag pontatlanul képesek csak megadni, tehát azok pontos pozícióit a PDB-ben tárolt szerkezetek nem tartalmazzák. Így a szerkezetet a hidrogének koordinátáival ki kell egészíteni a kísérleti körülményeknek megfelelően. Azaz a hiányzó hidrogének preferált elhelyezkedéseinek meghatározása (a kísérleti körülményeknek megfelelően, a 7,4-es kémhatáshoz tartozó protonáltsági állapotok figyelembevételével - a legvalószínübb mikroállapot), illetve a szerkezeti vizek orientációjának meghatározása a MOE programcsomag Protonate3D modulja felhasználásával történt (CCG 2007). A program az ismert nehézatom pozíciók alapján képes viszonylag nagy pontossággal meghatározni a hidrogének elhelyezkedését (Labute 2009).

$\mathrm{Az}$ enzimszerkezet tanulmányozása során elsősorban a legerősebb másodlagos kölcsönhatásokat, a hidrogénkötéseket illetve azok a hálózatát vizsgáltuk. Ehhez először a hidrogénkötést kellett definiálni, amihez a következö szerkezeti kritériumokat használtuk (Brown és mts., 2005):

- a donor és az akceptor atomok közötti távolság nem lehet több mint $3.5 \AA$, és

- a donor és az akceptor atomok által megadott vektor, illetve az akceptor atom és a hidrogén atom által definiált vektor közötti szög nem lehet nagyobb, mint 30 fok (4. ábra).
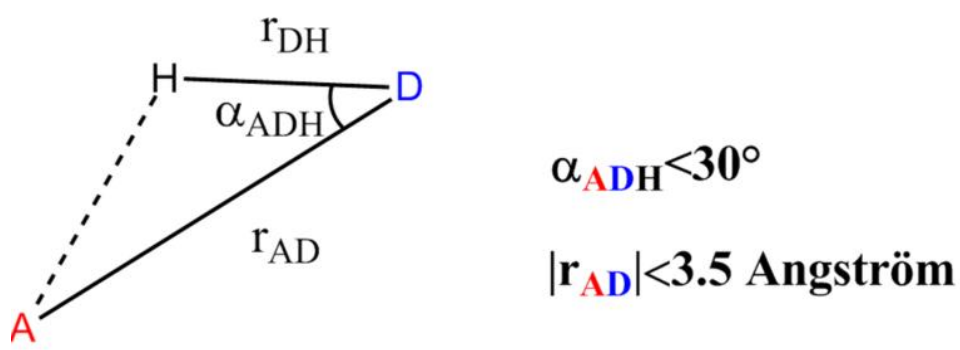

4. ábra: A hidrogénhíd kötés szerkezeti kritériumai. Piros színnel az akceptor atom (A), kékkel pedig a donor atom (D) van jelölve.

$\mathrm{Az}$ ily módon definiált hidrogénhidas kapcsolatok felderítéséhez a VMD programot használtuk (Humphrey és mts., 1996).

A fehérjerészletek és a szerkezeti vizek számozása 1WUL.pdb-ben található adatoknak megfelelően történt. Az aminosavrészletek elnevezéséhez az AMBER hárombetűs jelölését vettük alapul, amelyben a hisztidinnek a protonáltsági mikroállapotának megfelelően három 
elnevezése van. A HID jelöli azt az állapotot, amikor csak a delta helyzetü nitrogén protonált. Amikor csak az epszilon helyzetű nitrogén protonált, a HIE kódot használjuk. Ha mindkét nitrogén protonált, azaz a hisztidin egyszeresen pozitív állapotban van jelen, akkor HIP-ként jelöljük (5. ábra).

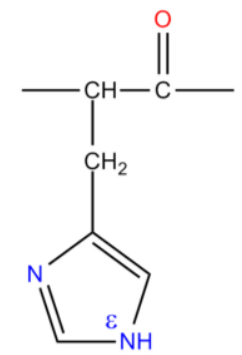

HIE

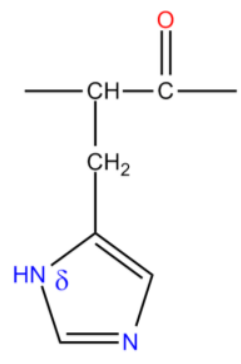

HID

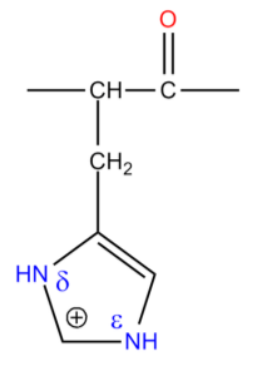

HIP

5. ábra: A hisztidin lehetséges protonáltsági állapotai. HIE: $\varepsilon$ helyzetủ nitrogén protonált, HID: $\delta$ helyzetủ nitrogén protonált, HIP: $\varepsilon$ és $\delta$ helyzetủ nitrogének protonáltak. 


\section{Eredmények}

\section{A His-gazdag motívum azonosítása a [NiFe] hidrogenázokban}

A már ismert [NiFe] hidrogenáz kristályszerkezetek elemzése révén számos konzervált szekvenciarészlet, vagy konkrét aminosav az enzim müködése során betöltött szerepére derült már fény. Ezen jól jellemzett szekvenciákon kívül, a [NiFe] hidrogenázok elsődleges aminosavsorrendjének összehasonlításakor megfigyeltem egy erősen konzervált,

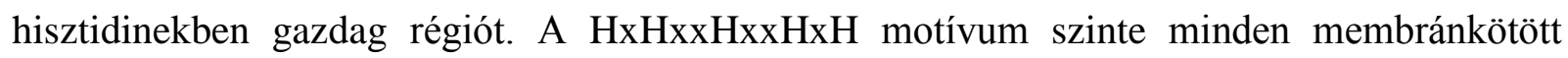
[NiFe] hidrogenázban jelen van, viszont a citoplazmatikus hidrogenázokban az öt hisztidin közül csupán kettő helye volt mindig konzervált (6. ábra). A hisztidin-gazdag szekvenciarészlet lehetséges szerepének vizsgálatához a $T$. roseopersicina HynSL enzimét használtam modellként.

$102 \underline{104} 107 \underline{110} 112$

\begin{tabular}{|ll|}
\hline T.r. & FVHDHVMHFYHLHALDWVDVVSALSADPKAT \\
A.V. & YIHDHVMHFYHLHALDWVDVVSALSADPRAT \\
R.c. & QIHDHIVHFYHLHALDWVNPVNALRADPKAT \\
M.c. & QAHDHLVHFYHLHALDWVDVVNALKADPKAT \\
B.j. & QVHDHVVHFYHLHALDWVDVVSALSADPRAT \\
Rh.l. & QVHDHVVHFYHLHALDWVDVVSALSADPKAT \\
R.e. & QVHDHAVHFYHLHALDWVDVMSALKADPKRT \\
D.V. & YLHDHIVHFYHLHALDFVDVTAALKADPAKA \\
D.g. & YMHDHLVHFYHLHALDWVNVANALNADPAKA \\
D.f. & YLHDHLVHFYHLHALDWVDVTAALKADPNKA
\end{tabular}

6. ábra: A konzervált helyzetű hisztidinek elrendeződése.

T.r.: Thiocapsa roseopersicina HynL, A.v.: Allochromatium vinosum HydL, R.c.: Rhodobacter capsulatus HupL, M.c.: Methylococcus capsulatus, B.j.: Bradyrhizobium japonicum HupL, Rh.1.: Rhizobium leguminosarum HupL, R.e.: Ralstonia eutropha H16 HoxG, D.v.: Desulfovibrio vulgaris Miyazaki F HynB, D.g.: Desulfovibrio gigas HynB, D.f.: Desulfovibrio fructosovorans HynB. Az illesztett szekvenciák felett látható számok a T.r. HynL-ben található konzervált His-ek pozícióját jelzik. Az His104-nek és His110-nek megfelelő pozícióban lévő aminosavak találhatóak meg citoplazmatikus hidrogenázokban. 


\section{A His-gazdag motívum funkcionális analízise T. roseopersicina HynL alegységében irányított mutagenezissel}

\subsection{Az egyszeres-His mutánsok elkészitése}

A régió szerepét irányított mutagenezis módszerrel vizsgáltam, mivel ez a technika alkalmas arra, hogy a kérdéses aminosav kicserélésével az enzim fenotípusában bekövetkező változásokat specifikusan tudjuk vizsgálni. Először a hynL génben egyszeresen mutáns konstrukciókat hoztam létre, melyekben az egyes konzervált hisztidineket kódoló régiókat egyesével alanint kódoló tripletekre cseréltem ki. A hisztidin egy poláros, hidrofil aminosav egy imidazol gyürủvel, ami proton felvételére képes (5. ábra). Így az alanin azért tűnt jó választásnak, mivel apoláros és hidrofób tulajdonságaiból adódóan valószínűleg nem tudja betölteni a hisztidin lehetséges szerepét az enzim müködése során.

A mutagenezis kísérletekhez egy olyan plazmid keresése volt szükség, mely széles gazdaspecifitású (azaz képes replikálódni E. coli és $T$. roseopersicina sejtekben is), tartalmazza a $T$. roseopersicina hynS-isp1-isp2-hynL operont, és amelyröl a HynSL enzimet aktívan ki tudjuk fejeztetni homológ gazdában. Erre a célra a pTHOE5M vektort használtam, mely megfelelt a fenti kritériumoknak (Keen és mts., 1988, Fodor nem közölt munka). Ez a konstrukció szolgált kiindulópontként a mutációkat hordozó vektorok elkészítéséhez, illetve az erről kifejeződő enzim egyúttal a vad típusú pozitív kontrollt is jelentette.

A pTHOE5M vektorból egy 3273 bp-os darabot (amely többek között tartalmazta a teljes nagy alegység génjét) ApaI restrikciós enzimmel kivágtam és pBluescriptSK+ plazmidba építettem. Az így kapott konstrukciót pBtHynLApa-nak neveztem el. Ezen a plazmidon végeztem el az irányított mutagenezist, tehát a pBtHynLApa volt a templát a PCR reakciók során. A mutagenezis kísérleteket az Anyagok és módszerek fejezetben ismertetett módon végeztem. A reakciókhoz szükséges oligonukleotid párok (2. táblázat) minden esetben mindkét szálon tartalmazták a kívánt mutációt. A reakció föbb lépéseit a 7. ábra foglalja össze. 


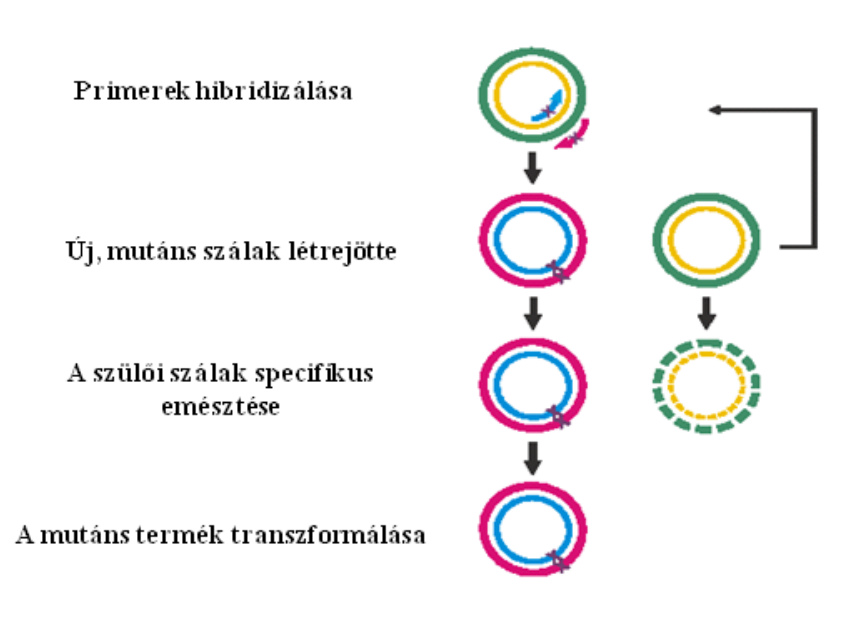

7. ábra: Az irányított mutagenezis fôbb lépései.

A mutagenezis eredményeképpen sikerült a 102-es, 104-es, 107-es, 110-es és a 112-es pozícióban levő hisztidineket kódoló tripleteket egyesével alanint meghatározó nukletidokra cserélni. Az új, mutáns nukleotid sorrendü hynL gént hordozó vektorokban tehát egyszerre csak egy konzervált hisztidint kódoló régió lett alaninnak megfelelő bázistriplettel helyettesítetve (az elkészített konstrukciók listája az 1-es táblázatban található). A mutációk ellenőrzésére szekvenciasorrend meghatározást végeztem.

Következő lépésként a módosított aminosavsorrendü nagy alegység fragmenteket tartalmazó pBluescriptSK+ plazmidokból a 3273 bp méretü ApaI fragmenteket kivágtam, és az ApaI restrikciós enzimmel emésztett pTHOE5M plazmidba illesztettem be (8. ábra). A kapott mutációs konstrukciókat az 1-es táblázat tartalmazza.
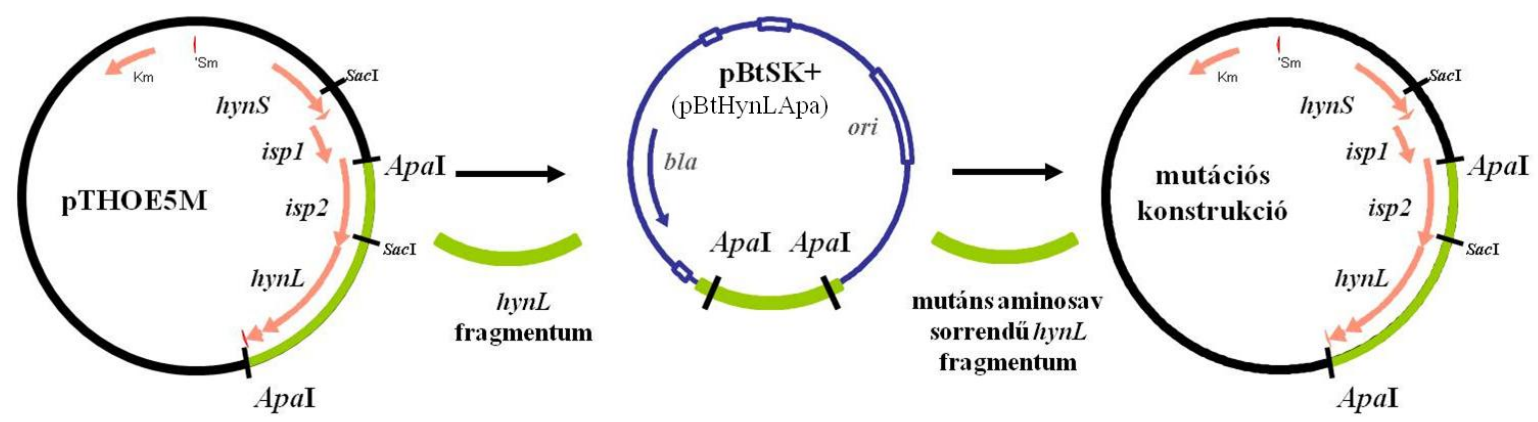

8. ábra: A mutáns konstrukciók készítése. 
A T. roseopersicina-ba bejuttatandó konstrukciók a pMH102A, pMH104A, pMH107A, pMH110A illetve a pMH112A nevet viselték, jelezve, hogy a plazmidról expresszálódó Hyn hidrogenáz nagy alegységében mely pozícióban lévő hisztidin aminosavak helyett fog alanin beépülni a fehérje szintézise során. Az elkészült konstrukciókat konjugációval juttattam be a GB112131 (AhynL, $4 h u p L, \Delta h o x 1 H$ mutáns) törzsbe, ahol a Hyn, a Hup és a Hox1 enzimek aktívan nem fejeződnek ki a genomról, a Hox2 pedig az általam használt mérési körülmények között nem aktív (J. Maroti és mts., 2010). Ezáltal lehetőségem volt szelektíven vizsgálni a mutáció hatását in vivo és in vitro körülmények között is. A mutációt hordozó HynSL enzimet kifejező T. roseopersicina törzseket a következőképpen neveztem el: MH102A, MH104A, MH107A, MH110A, MH112A (tehát a törzsnévben is szerepel, hogy a GB112131 törzs mely plazmid konstrukciót tartalmazza).

\subsection{Az egyszeres His-mutánsok aktivitásának vizsgálata in vivo és in vitro körülmények között}

Az egyszeresen mutáns fehérjét hordozó törzsek hidrogenáz aktivitását megvizsgáltam in vivo (saját elektrondonor/akceptor használata) és in vitro (mesterséges elektrondonor/akceptor használata) körülmények között is pozitív és negatív kontrollok mellett. A méréseknél használt pozitív kontroll a GB112131 + pTHOE5M törzs volt, melybe a HynSL-t kódoló régiót a pTHOE5M plazmid révén juttattam vissza a GB112131 törzsbe. Az így kapott GB112131 + pTHOE5M törzsben tehát specifikusan lehet vizsgálni a vad típusú Hyn hidrogenáz müködését. Minden esetben a GB112131 törzs jelentette a kísérletekben használt negatív kontrollt. Az enzimek in vivo hidrogéntermelő aktivitás változásának vizsgálatához az egyes sejtkultúrákat anaerob körülmények között, standard Pfennig-féle tápoldatban növesztettem, majd a felnőtt kultúrák által (a leoltástól számított 6. napig) megtermelt hidrogén mennyiségét mértem. A kontrollok és a mutáns törzsek növekedési rátája hasonló volt (amit az egyes sejtkultúrák 600 nm-en mérhető optikai denzitásának meghatározásával folyamatosan nyomon követtem), és a hidrogéntermelésük is azonos időben indult be. Az egyes mutánsok hidrogéntermeléséből következtetni lehet a mutáns aminosavsorrendủ HynSL hidrogenáz enzim hidrogénfejlesztő aktivitására. A párhuzamos mérések eredményeiből számolt statisztika azt mutatta, hogy az egyes aminosav cserék 
különbözőképpen hatnak a HynSL hidrogenáz müködésére. Az in vivo hidrogéntermelés csak az MH104A mutáns esetében változott jelentősen, 40\%-ra esett vissza a pozitív kontroll hidrogéntermelő képességéhez képest (3. táblázat). Az MH102A, MH107A, MH110A, MH112A egyszeres mutánsoknál a hidrogéntermelés nem csökkent számottevően, aktivitásuk átlagosan mindössze 20\%-kal maradt el a pozitív kontroll hidrogéntermelésétől (3. táblázat).

A mutáns és kontroll törzsek hidrogenáz aktivitását hat napig történő növesztés után in vitro körülmények között is megvizsgáltam. A hidrogénfelvevő aktivitás nem változott jelentősen az MH102A, MH107A, MH110A illetve az MH112A mutánsoknál, míg azon törzs esetében, ahol a HynL His104-es aminosavát kicseréltem alaninra, az enzim aktivitása drasztikusan lecsökkent (3. táblázat).

\section{Táblázat: A Thiocapsa roseopersicina HynSL enzim aktivitása in vivo és in vitro.}

(Az MR487I, MD103L, MH104F, ME436I, ME14Q mutánshoz tartozó mérési eredmények a dolgozatban később kerülnek tárgyalásra)

\begin{tabular}{|cccc|}
\hline \multirow{2}{*}{ Törzsek megnevezése } & In vivo & In vitro & In vitro \\
\cline { 2 - 4 } & $\mathbf{H}_{\mathbf{2}}$-termelés $(\boldsymbol{\%})$ & $\mathbf{H}_{\mathbf{2}}$-termelés $(\boldsymbol{\%})$ & $\mathbf{H}_{\mathbf{2}}$-felvétel (\%) \\
\hline GB112131 & 0 & 0 & 0 \\
GB112131+pTHOE5M & $100.0 \pm 0.0$ & $100.0 \pm 0.0$ & $100.0 \pm 0.0$ \\
MH102A & $91.8 \pm 20.8$ & $64.5 \pm 16.8$ & $67.7 \pm 7.4$ \\
MH104A & $39.5 \pm 8.0$ & $6.1 \pm 5.2$ & $18.2 \pm 13.7$ \\
MH107A & $88.9 \pm 15.2$ & $78.6 \pm 3.6$ & $85.6 \pm 6.9$ \\
MH110A & $71.4 \pm 7.4$ & $73.5 \pm 8.7$ & $95.2 \pm 6.6$ \\
MH112A & $81.8 \pm 22.0$ & $65.9 \pm 13.3$ & $76.8 \pm 18.4$ \\
MH102/104/107/110/112A & $32.5 \pm 0.0$ & $19.5 \pm 7.3$ & $32.2 \pm 18.4$ \\
MH102/107/110/112A & $57.7 \pm 4.4$ & $63.7 \pm 10.3$ & $85.1 \pm 12.5$ \\
MR487I & 0 & 0 & 0 \\
MD103L & 0 & 0 & 0 \\
MH104F & $43.2 \pm 16.8$ & 0 & $5.5 \pm 2.8$ \\
ME436I & $29.68 \pm 12.4$ & $50.9 \pm 7.8$ & $54.58 \pm 13.2$ \\
ME14Q & 0 & $51.2 \pm 5.6$ & $46.81 \pm 3.8$ \\
\hline
\end{tabular}




\subsection{A mutáns enzimek stabilitásának és sejten belüli elhelyezkedésének vizsgálata}

Annak érdekében, hogy igazoljam az MH104A törzsnél tapasztalt aktivitáscsökkenés valóban az aminosav csere következménye és nem az enzim bioszintézisében bekövetkező hiba, vagy az enzim csökkent proteolitikus stabilitása áll a háttérben, Western-hibridizációs kísérleteket végeztem (9. ábra).

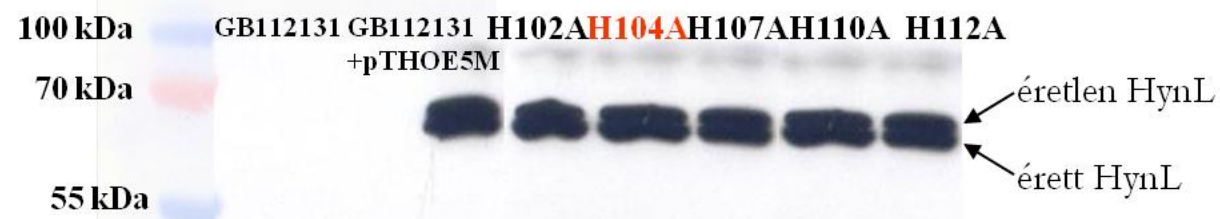

9. ábra: Az egyszeres aminosav mutáns fehérjék összehasonlítása Western-hibridizációs kísérlettel.

A HynL fehérje detektálására Anti-HupL antitestet használtam. Az egyes oszlopokban $50 \mu \mathrm{g}$ összfehérjét futtattam. A felső fehérje sáv az éretlen HynL-nek felel meg, míg az alsó az érett nagy alegységet jelenti. GB112131: T. roseopersicina $\triangle$ hynSL, $\triangle$ hupSL, 4 hoxH1 törzs, a negatív kontroll; GB112131+pTHOE5M: $T$. roseopersicina $\triangle$ hynSL, $\triangle$ hupSL, $\triangle$ hoxH1 törzs + vad típusú HynSL fehérjét expresszáló vektor, pTHOE5M, a pozitív kontroll; mutáns törzsek: H102A: T. roseopersicina MH102A törzs, H104A: T. roseopersicina MH104A törzs, H107A: T. roseopersicina MH107A törzs, H110A: T. roseopersicina MH110A törzs, H112A: T. roseopersicina MH112A törzs.

A 9-es ábrán látható, hogy mind az érett, mind az éretlen Hyn nagy alegységének megfelelő fehérje sáv megfigyelhető volt mind a mutánsok, mind a pozitív kontroll esetében, és ezek a sávok egymástól jól elkülönülnek a közöttük lévő méretbeli különbség miatt, ami abból ered, hogy az éretlen HynL C-terminálisáról egy körülbelül $3 \mathrm{kDa}$ nagyságú darab vágódik le a fehérje érése során. Az is megállapítható, hogy mind az érett, mind az éretlen fehérje sávok vastagsága nagyjából azonos a mutánsoknál és a pozitív kontrollnál, ami arra enged következtetni, hogy az adott törzsekben megközelítőleg megegyezö a HynL fehérje mennyisége. Ebböl pedig azt a konklúziót vontam le, hogy az MH104A esetében tapasztalt aktivitás csökkenés valóban a mutáció következménye, és nem a fehérje csökkent stabilitása, vagy a H104A mutációt hordozó HynL bioszintézisének, érésének zavara miatti fehérje mennyiség csökkenés áll a háttérben.

Annak érdekében, hogy információt szerezhessek a mutáns enzimek sejten belüli elhelyezkedéséről, az in vitro $\mathrm{H}_{2}$ aktivitásméréseket is elvégeztem a kontroll és a mutáns törzsekből elóállított membrán és szolubilis frakciókat használva mintaként. Ezen 
kísérletekből kiderült, hogy a mutációk nem változtatták meg a Hyn fehérje és a membrán közötti kapcsolatot, a mutáns Hyn fehérjék továbbra is membránhoz asszociáltak maradtak. Bár a szolubilis minták mérésénél is detektáltam hidrogenáz aktivitást, mivel ez az aktivitás mind a mutáns törzsek, mind a pozitív kontroll esetében mérhető volt, kizárta annak a lehetőségét, hogy az általam okozott mutáció következtében került a hidrogenáz a felülúszó

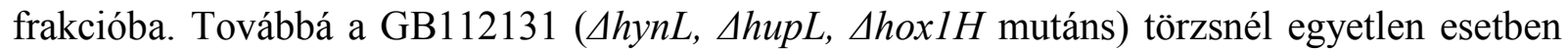
sem volt kimutatható enzimaktivitás, így nyilvánvalóvá vált, hogy a tapasztalt aktivitások a HynSL enzimhez tartoznak.

\subsection{A többszörös His-mutánsok és jellemzésük}

A His-gazdag motívum szerepének mélyebb megismerése érdekében további két mutáns törzset készítettem irányított mutagenezist használva. Az egyikben mind az öt konzervált hisztidin aminosavat kicseréltem alaninra (MH102/104/107/110/112A, a penta-His mutáns), míg a tetra-His mutáns esetében a mutációt hordozó konstrukció csak egyetlen konzervált hisztidint tartalmazott (His104), a motívum másik négy hisztidin aminosavát itt is alaninnal helyettesítettem (MH102/107/110/112A, tetra-His mutáns) (1. táblázat).

A kontroll és mutáns törzseket, a korábbiakhoz hasonlóan, hat napig növesztettem és a hatodik napon mértem az in vivo körülmények között termelődött $\mathrm{H}_{2}$ mennyiségét. Az MH102/104/107/110/112A törzs in vivo hidrogéntermelő aktivitása az egyszeres Hismutánsok közül az MH104A törzs hidrogéntermeléséhez volt nagyon hasonló, mindkét esetben a mutáns törzsek aktivitása a pozitív kontrollénak csupán 40\%-a volt. Viszont az MH102/107/110/112A törzsnél, ahol a H104 megmaradt vad típusúként, az in vivo hidrogénfejlesztés mértéke a pozitív kontroll hidrogéntermeléshez volt inkább hasonló (3. táblázat). A tetra-His, illetve a penta-His mutánsokkal végzett in vitro aktivitásmérések során kiderült, hogy az MH102/104/107/110/112A törzs aktivitása az MH104A mutáns ugyanilyen típusú aktivitásának szintjére csökkent. Azonban az MH102/107/110/112A törzsnél mért in vitro enzimaktivitás a pozitív kontroll aktivitásával volt összevethető (3. táblázat). 


\section{A hidrogénhíd hálózat modellezése}

A konzervált His aminosavak funkcióinak molekuláris szintü értelmezéséhez és ezáltal a hidrogenáz aktivitás vizsgálatokból származó eredmények pontosabb megértéséhez a hidrogenázok háromdimenziós szerkezeteinek elemzése vált szükségessé. Sajnos a $T$. roseopersicina HynSL hidrogenázának kristályszerkezete nem áll rendelkezésünkre. Bár létezik ezen hidrogenáz homológia modellje (Szilagyi és mts., 2002), aminek felépítéséhez a Desulfovibrio gigas hidrogenáz enzimét használták templátként (PDB ID: 2FRV, (Volbeda és mts., 1996)), azonban e többszörös szerkezetillesztéses modell nem tartalmazza a szerkezeti vizek, vagy legalább azok oxigénjének pozícióit. A szerkezeti vizek hiányában a fontos kölcsönhatások és protonáltsági állapotok nem felderíthetőek. Egy másik lehetőség, ha az általunk vizsgálni kívánt enzimmel nagyfokú homológiát mutató, ismert háromdimenziós szerkezetet elemzünk, amely tartalmazza az általunk vizsgálandó konzervált aminosavakat (a HynSL esetében az öt konzervált hisztidint és annak környezetét), illetve a szerkezeti vizek oxigénjeinek pozíciót. Így a D. vulgaris Miyazaki F. redukált állapotú [NiFe] hidrogenázának nagyfelbontású (1,5 Å) röntgenszerkezetét választottuk (PDB ID: 1WUL, (Ogata és mts., 2005)), melynek nagy alegységét vizsgáltuk, mint a $T$. roseopersicina HynL alegység modelljét.

A kristályszerkezet elemzése során egy olyan molekulaláncolatot figyeltünk meg, melynek tagjai (konzervált helyzetü aminosavak és vízmolekulák) erős hidrogénhíd kötésekkel kapcsolódnak egymáshoz, és összekötik a fehérje aktív centrumát a fehérje felszínével. A protonáltsági mikroállapotok és az enzim hidrogénhidas hálózatának meghatározási módszere részletesen az Anyagok és módszerek fejezetben található meg.

A hidrogenáz aktív helyén a pozitív töltésü nikkelt konzervált helyzetü ciszteinek koordinálják, mely komplextől 4,748 Å távolságra található a semleges töltésű Arg (Arg479). Az Arg479 extrém protonáltsági állapota (általában pozitív töltéssel rendelkezik) valószínúleg a pozitív töltésü Ni közelségének köszönhető. Az Asp123 és az Arg479 aminosavrészletek erős ionpárszerü szerkezetet alkotnak, amit jól jelez a két aminosavrészlet közötti kis kötéstávolság is (O@Asp123 és H@Arg479 közötti távolság 1,959 Å). Az Asp123 szintén kölcsönhat egy szerkezeti vízzel, ezáltal hidrogénhíddal kötve azt össze a következő, 1,8 távolságra lévő aminosavrészlettel (Hip124). Számításaink azt mutatták, hogy ez a hisztidin az 
egyedüli a vizsgált hisztidin motívumon belül, amely egyszeresen pozitív töltésü, mivel mind az $\varepsilon$, mind a $\delta$ nitrogénje protonált állapotú (5. ábra). A Hip124-es hisztidin másik nitrogénjéhez ( $\varepsilon$ ) kapcsolódó hidrogén erősen kötődik a 433-as Glu oxigénjéhez $(1,551 \AA$ Å). Ezt egy újabb rövid kötéstávolságú (1,731 Å) hidrogénhíd követi, amely összeköti a Glu433 aminosavrészletet a 390-es glutaminnal (Gln390). A lánc következő aminosav eleme a fehérjefelszínen elhelyezkedő Lys315, amely egy víz dimeren keresztül kötődik a korábban bemutatott hidrogénhidas hálózathoz (10. ábra). Fontos megjegyeznünk, hogy a fenti hálózat kezdeti elemei erősen konzerváltak (D. vulgaris számozás szerint Arg479, Asp123, Hip124 és a Glu433) a membránkötött hidrogenázok nagy részében, így a $T$. roseopersicina Hyn hidrogenázában is (11. és 12. ábra). A vizsgált $H x H x x H x x H x H$ motívum többi hisztidinje semleges töltésünek bizonyult (Hie122, Hie127, Hie130 és Hie132), és a hidrogénhidas hálózatuk is kevésbé kiterjedt.

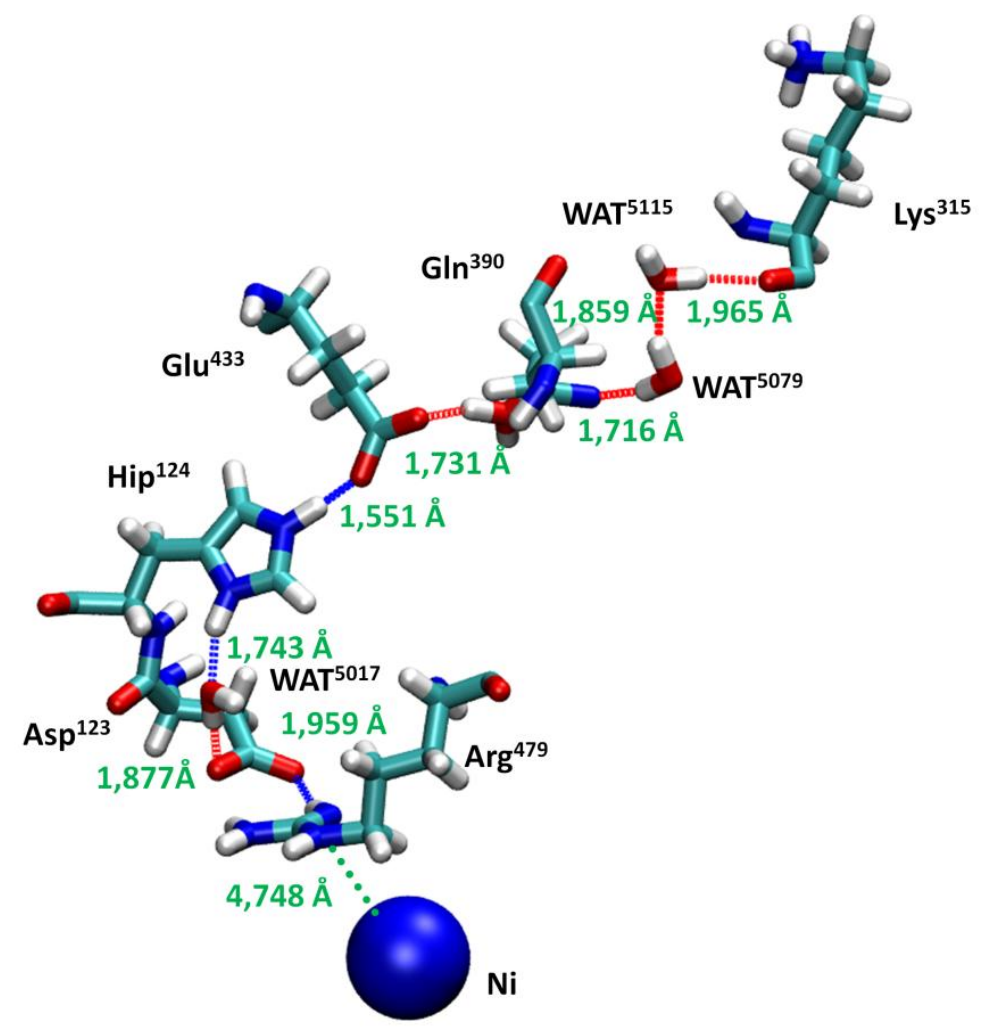

10. ábra: A Desulfovibrio vulgaris Miyazaki F. (PDB: 1WUL) struktúra alapján javasolt protontranszfer útvonal. Világoskék színnel vannak jelölve a szén, kékkel a nitrogén, pirossal az oxigén, fehér színnel pedig a hidrogén atomok. Az ábrán a nikkelt a kék gömb jelzi. A láncolatot alkotó tagok közötti távolságok Angströmben vannak megadva. 
Ogata és munkatársai 2010-ben publikálták az A. vinosum (PDB ID: 3MYR, (Ogata és mts., 2010)) membránkötött [NiFe] hidrogenázának kristályszerkezetét. Bár ez az enzim nagyobb szekvenciaazonosságot mutat a $T$. roseopersicina membránkötött hidrogenázaival, mint a D. vulgaris Miyazaki F. hasonló típusú fehérjéivel, az A. vinosum-ból származó kristályszerkezet felbontása nem olyan jó, mint a $D$. vulgaris esetén. Megvizsgálva az A. vinosum hidrogenázának szerkezetét, azonosítottunk egy, a fent ismertetetthez hasonló hidrogénhidas hálózatot, melynek tagjai: Arg487-Asp103-WAT3408-His104-Glu436. Érdemes megjegyezni, hogy a szerkezeti vizekhez tartozó oxigének pozíciói szintén konzerváltnak tünnek. A flexibilis hurokkal fedett hidrogénhidas hálózat, a Glu436 után, az Arg393-Glu484-WAT3505 tagokkal folytatódik (az aminosavak az A. vinosum elsődleges szekvenciájának megfelelő számozással szerepelnek, míg a jelzett vízmolekulák 3MYR kristályszerkezet szerinti számozással vannak feltüntetve).

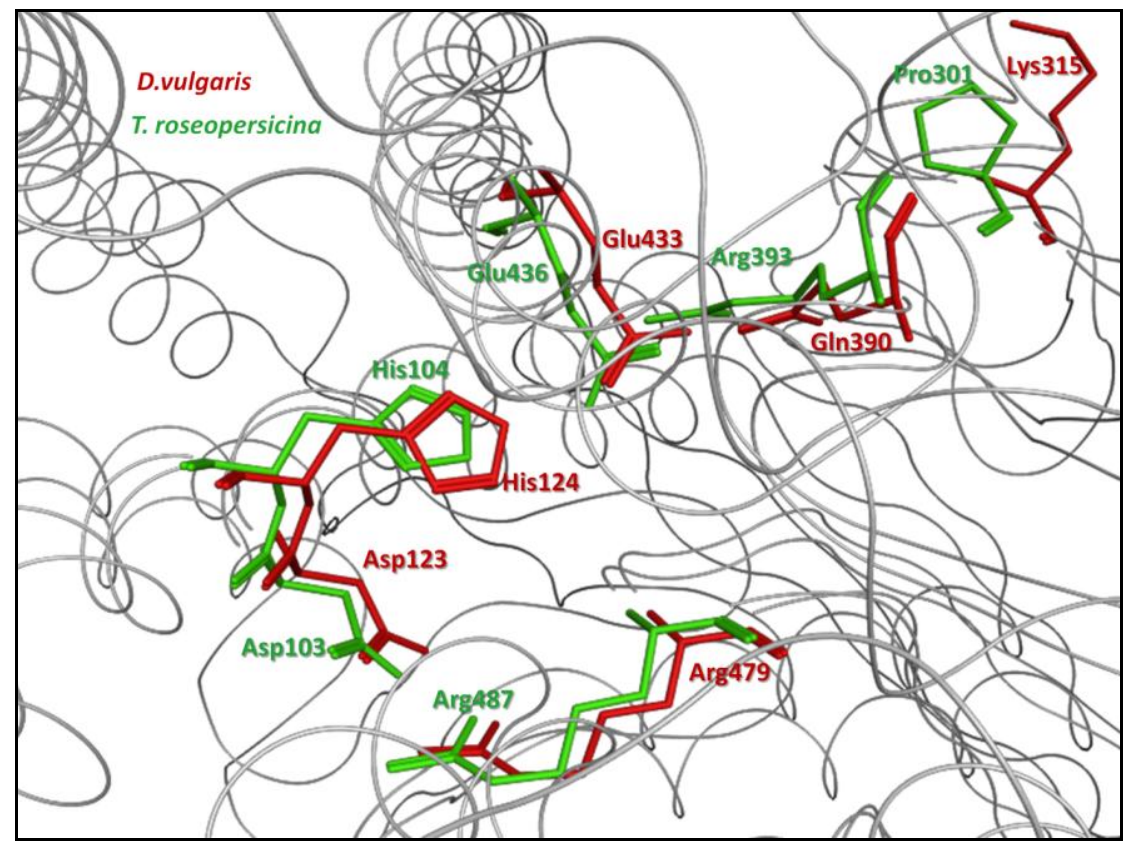

11. ábra: A feltételezett protontranszfer útvonal aminosavainak illesztése $D$. vulgaris Miyazaki $F$. struktúrája (1WUL.pdb) és a T. roseopersicina homológia modellje (HynL.pdb, (Szilagyi és mts., 2002)) alapján. Piros színnel jelöltük a $D$. vulgaris $\mathrm{HynB}$ aminosavait, míg zölddel a $T$. roseopersicina $\mathrm{HynL}$ hidrogenázának aminosavait. Az ábrázolt aminosavakat körülvevő fehérje mátrix szürke színủ. 


\section{Az elméleti modell kísérletes bizonyítása}

A rendelkezésre álló térszerkezetek számítógépes analízise alapján meghatároztunk egy erős hidrogénhíd kötésekkel egymáshoz kapcsolódó, konzervált aminosavakból és vízmolekulákból álló láncolatot (Arg479, WAT5017, Asp123, Hip124, Glu433, Gln390, WAT5079, WAT5115, Lys315; D. vulgaris Miyazaki F. szerinti számozás), melyről feltételeztük, hogy protoncsatornaként funkcionálhat a hidrogenázok müködése során. Érdemes megjegyezni, hogy az enzim aktív centrumának közelében lévő, a dolgozatban javasolt protoncsatorna tagjaiként szereplö Arg479 és His124 aminosavak (Arg463, His108 a D. gigas-ban, és Arg487, His104 a T. roseopersicina-ban) már egy korábbi tudományos közleményben is megjelentek, mint egy lehetséges protontranszfer útvonal szereplői (Fontecilla-Camps és mts., 2007). Annak érdekében, hogy elméleti modellünket igazoljam, a T. roseopersicina HynSL hidrogenázát használva modellként, a feltételezett protoncsatorna első négy aminosavát (Arg487, Asp103, His104, Glu436 T. roseopersicina számozás szerint) jelöltem ki mutagenezisre, mivel a csatorna következő tagjai nem teljesen konzerváltak a membránkötött hidrogenázok esetében (11. és 12. ábra). 


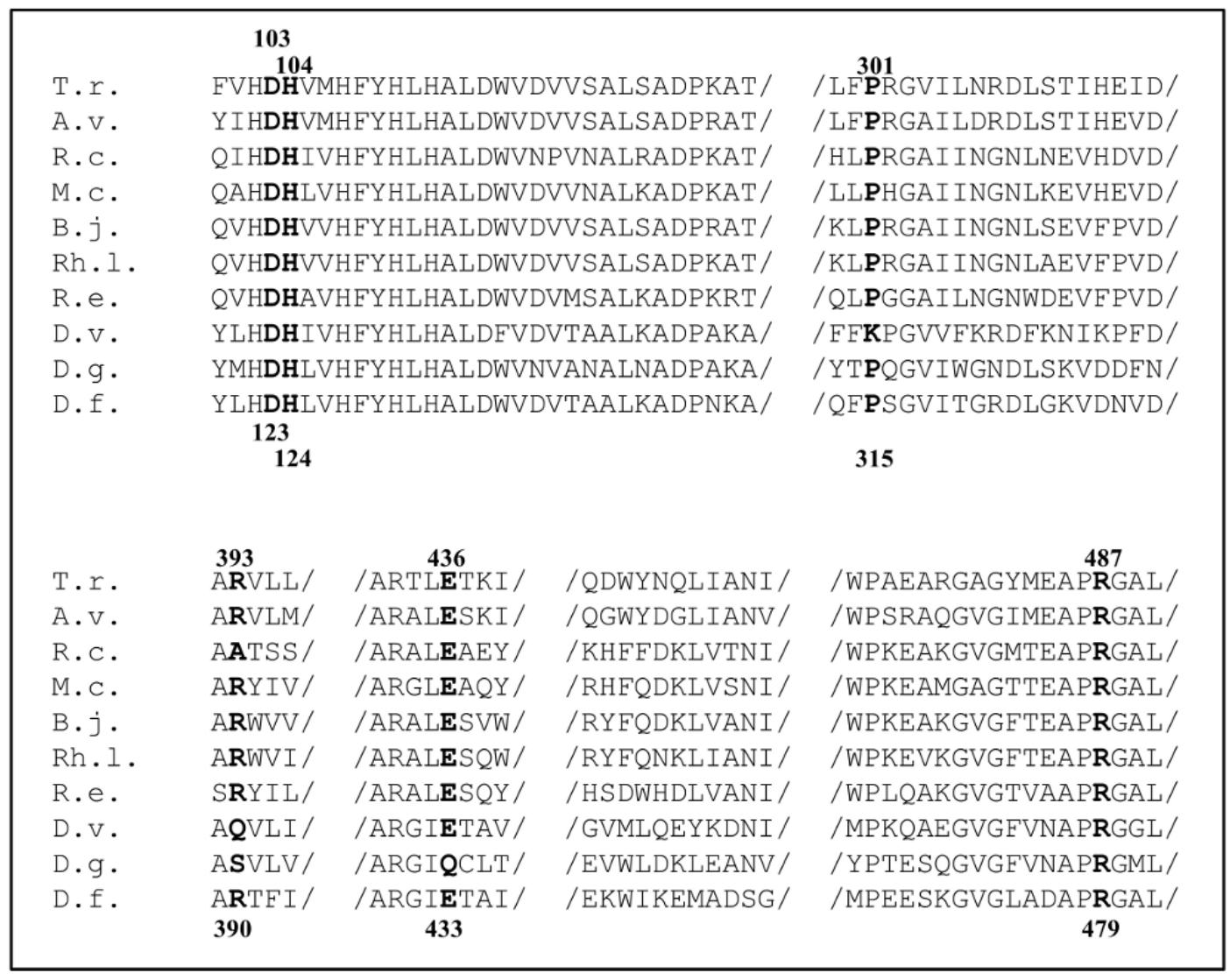

\section{2. ábra: A feltételezett protoncsatornát alkotó konzervált aminosavak összehasonlítása.}

T.r.: Thiocapsa roseopersicina HynL, A.v.: Allochromatium vinosum HydL, R.c.: Rhodobacter capsulatus HupL, M.c.: Methylococcus capsulatus, B.j.: Bradyrhizobium japonicum HupL, Rh.1.: Rhizobium leguminosarum HupL, R.e.: Ralstonia eutropha H16 HoxG, D.v.: Desulfovibrio vulgaris Miyazaki F HynB, D.g.: Desulfovibrio gigas HynB, D.f.: Desulfovibrio fructosovorans HynB. Az oszlopok felett a T. $r$.-nak megfelelő számozás látható, míg alul a $D . g$. szerinti számozás található.

Munkám során a vizsgált protoncsatornát alkotó aminosavakat protonálódásra nem képes, de az eredetihez hasonló térkitöltésủ aminosavakra cseréltem. Ez utóbbi kritériumra azért volt szükség, hogy kiküszöböljem annak a lehetöségét, ami kis térkitöltésü aminosavak (pl. alanin, glicin) esetén előfordulhat, azaz a protoncsatornaként müködő molekula láncolat a mutagenezis után is funkcionális maradhat. Ez alapvetően két dolog miatt következhet be: kis térkitöltésü, protonálódásra nem képes aminosavak esetén vagy egy újabb szerkezeti vízmolekula lép be a molekulaláncolatba, vagy a mutagenezist követően a helyettesített aminosav elötti és az utána következő tag a protonátmenethez még elegendő távolságra marad. A mutáció hatását egyik esetben sem tudnánk észlelni, hiszen a proton a köztes aminosavat kihagyva tovább vándorolhat a láncolatban. Ennek megfelelően az Arg487-et és a Glu436-ot 
Ile-nal, az Asp103-at Leu-nal, a His104-et pedig Phe-nal helyettesítettem, majd az új mutánsok aktivitását hasonlítottam össze a vad típusú enzim aktivitásával. A kísérletekben használt protoncsatorna-mutáns törzsek listáját az 1-es táblázat tartalmazza. A mutáns enzimek in vitro hidrogénfelvevő és hidrogéntermelő kapacitását az Anyagok és módszerek fejezetben bemutatott módszerekkel vizsgáltam. Az MR487I és az MD103L mutánsok esetében az enzim teljesen elveszítette aktivitását in vitro körülmények között, míg az ME436I és ME14Q törzsekben a HynSL enzim aktivitása a pozitív kontroll aktivitásának nagyjából 50\%-a maradt (3. táblázat). Az MH104F mutánsnál jelentősen lecsökkent az enzim in vitro hidrogénfelvevő aktivitása, a vad típusú enzim aktivitásának csupán $6 \%$ volt. Ez nagyban hasonlít a korábbi, MH104A törzs esetében mérhető aktivitás értékekhez. Az in vitro hidrogéntermelés a mérési határ alá csökkent, így nem tudtam detektálni (3. táblázat).

A mutáns enzimek proteolitikus stabilitását és az érés pontos végbemenetelét itt is Western-hibridizációs kísérletekkel követtem nyomon. Mivel az MH104A és az MH104F mutánsok in vitro hidrogenáz aktivitása nagyban hasonló volt, a Western kísérletek esetében az előbbit használtam (13. ábra).

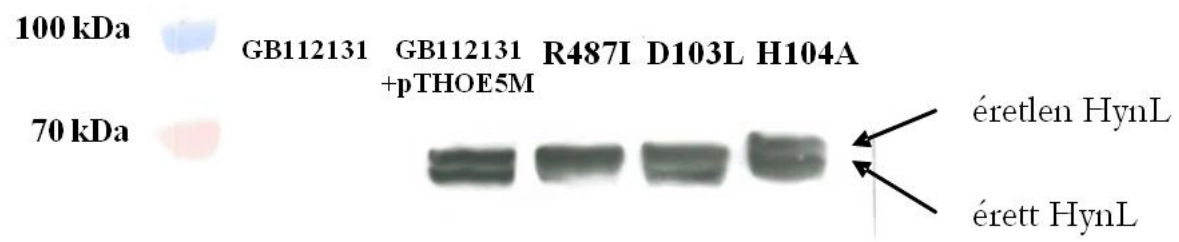

$55 \mathrm{kDa}$

\section{3. ábra: A javasolt protoncsatorna kialakításában résztvevő aminosav mutáns törzsek ellenőrzése Western-hibridizációs kísérlettel.}

A HynL detektálásához Anti-HupL ellenanyagot használtunk, az egyes oszlopokban $25 \mu \mathrm{g}$ összfehérjét tartalmazó minta volt futtatva mind a mutáns, mind a kontroll törzsek esetében.

GB112131: T. roseopersicina $\triangle$ hynSL, $\triangle$ hupSL, 4 hoxH1 törzs, a negatív kontroll; GB112131+pTHOE5M: $T$. roseopersicina $\triangle$ hynSL, $\triangle$ hupSL, 4 hoxH1 törzs + vad típusú HynSL-t expresszáló vektor, pTHOE5M, a pozitív kontroll. Mutáns törzsek: R487I: T. roseopersicina MR487I törzs, D103L: T. roseopersicina MD103L törzs, H104A: T. roseopersicina MH104A törzs.

$\mathrm{Az}$ 13. ábrán a vad típusú enzim, az MD103L, illetve az MH104A mutánsoknál jól elkülöníthetőek az érett és az éretlen fehérje sávok, míg az MR487I törzsnél föként az éretlen forma volt detektálható. 


\section{A D. fructosovorans-ban leírt Glu14-es útvonal jellemzése $T$. roseopersicina-ban}

A Desulfovibrio fructosovorans-szal végzett kiterjedt kísérletek során sikerült igazolni, hogy a Glu25-ös aminosav (Glu14 a T. roseopersicina-ban) esszenciális a hidrogenáz enzimekben lejátszódó proton-transzlokáció folyamatában (Dementin és mts., 2004). A kérdéses aminosav szerepét $T$. roseopersicina-ban is megvizsgáltam, a megfelelő Glu-t Gln-ra cseréltem, majd összehasonlítottam a mutáció hatását a D. fructosovorans Glu25Gln mutáns esetében tapasztalt eredményekkel (Dementin és mts., 2004). A T. roseopersicina esetében a mutáns HynSL hidrogenáz enzim in vitro aktivitása a vad típusú enzim aktivitásának 50\%-át mutatta, míg a $D$. fructosovorans Glu25Gln mutánsának ugyanezen típusú enzim aktivitása teljesen megszűnt. E két organizmus nem áll közeli rokonságban egymással, továbbá a kísérleteimben teljes sejtextraktumot használtam tisztított fehérjék helyett (D. fructosovorans esetében ez utóbbi történt), ezért elképzelhető, hogy ugyanazon típusú mutációnak különböző mértékủ hatását figyeltem meg. Továbbá feltételezhetően több alternatív útvonal is létezik az enzim felszíne és aktív centruma közötti protontranszfer lebonyolítására, kísérleteim eredménye erre is utalhat. 


\section{Diszkusszió}

Napjainkban számos [NiFe] hidrogenáz elsődleges szekvenciája ismert, melyek összehasonlítása sok, az enzim müködésében is fontos szerkezeti elem felderítésére ad lehetőséget. Így került korábban leírásra öt olyan konszenzus szekvencia (L1-L5), melyek általánosan jellemzőek ezen enzimek nagy alegységeire (Albracht 1994), s a [NiFe] hidrogenázok kristályszerkezeteinek elemzéséből származó információk, összhangban a kísérletes eredményekkel, arról is felvilágosítást nyújtottak, hogy egyes konzervált régiók milyen szerepet töltenek be az enzim müködése során. A periplazmatikus [NiFe] hidrogenázok közül elsőként a Desulfovibrio gigas enzimének kristályosítása járt sikerrel. Így a [NiFe] hidrogenáz enzimek szerkezetére vonatkozó információk nagy része ezen kristályszerkezet elemzéséből vált ismertté. Fontos megállapítás volt, hogy az enzim aktív centrumát alkotó fémionok mélyen a fehérje belsejében találhatóak (Volbeda és mts., 1995), és a Ni és Fe ionok az L2 és L5 CxxC motívumainak cisztein aminosavai révén koordinálódnak. Az L5-ös konszenzus szekvencia a hidrogenázok bioszintézisében is fontos szerepet tölt be, hiszen a Cx2Cx2H/R motívum a fehérjék érése során bekövetkező C-terminális endoproteolitikus hasításának helye. Az endopeptidázok az említett régió konzervált His (vagy Arg) aminosava után hasítanak, mely szükséges feltétele a nagy alegység helyes összeszerelödésének (Vignais és mts., 2004). Nagyjából 25-32 aminosav hosszúságú szakaszt vág le az enzim a fehérje Cterminálisáról, majd az ily módon éretté vált nagy alegység már képes összekapcsolódni, és funkcionális dimert alkotni a kis alegységgel. Az L3 motívumot (Hx6L) alkotó aminosavak az aktív centrum $\mathrm{Ni}$ ionja közelében vannak. Ezen konszenzus szekvencia nagy részét a dolgozatban elemzett His-gazdag motívum képezi.

A fent említett, jól ismert és részletesen elemzett motívumokon kívül a membránkötött hidrogénfelvevő hidrogenázok a kis alegységük N-terminálisán rendelkeznek egy erősen konzervált, hosszú szignál szekvenciával (nagyjából 35-50 aminosav). A [DENST]RRxFxK motívumot a hidrogenázok speciális transzlokációját végző fehérjék ismerik fel (membrane targeting and translocation, Mtt vagy twin-arginine translocation, Tat útvonal), majd a megfelelően összeszerelődött heterodimert a sejtmembránba szállítják (Vignais és mts., 2007). Számos olyan további konzervált régió vagy aminosav ismert a [NiFe] hidrogenázoknál, 
melyeknek fontos szerepe van például: fémek koordinálásában ( $\mathrm{Mg}$ ion) (Ogata és mts., 2009), elektrontranszferben (Volbeda és mts., 1995, Dementin és mts., 2006), protontranszferben (Dementin és mts., 2004), különböző gázmolekulák aktív centrum felé, vagy az aktív centrum felöl történő továbbításában, oxigénnel szembeni érzékenység/rezisztencia kialakításában (Volbeda és mts., 2002, Buhrke és mts., 2005, Duche és mts., 2005, Leroux és mts., 2008, Dementin és mts., 2009, Liebgott és mts., 2010), illetve más fehérjékkel történő interakció kialakításában (Vignais és mts., 2007).

\section{A membránkötött [NiFe] hidrogenázok His-gazdag régiójának lehetséges szerepe}

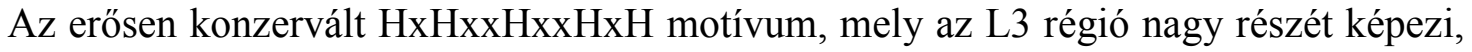
a különböző membránkötött hidrogenázok nagy alegységében a 100-130. aminosavak régiójában helyezkedik el. A [NiFe] hidrogenázok szekvencia összehasonlítása során kiderült, hogy a konzervált hisztidinek közül csupán kettő van jelen a citoplazmatikus hidrogenázokban (H104 és H110, T. roseopersicina számozása szerint). A T. roseopersicina HynSL fehérjéjét használva modellként, kísérleteimben számos különbözö, a hynL génben mutáns törzs került kialakításra irányított mutagenezissel annak érdekében, hogy a mutációt hordozó gének termékeinek vizsgálatával fényt deríthessek ezen régió pontos szerepére.

A [NiFe] hidrogenázokra jellemző His-gazdag motívum teljes egészében elsősorban a membránkötött enzimekben található meg, ezért szerettem volna megvizsgálni, hogy ezek a konzervált aminosavak összefüggésben állhatnak-e az adott hidrogenázok membránhoz való kötődésében. A mutáns enzimek sejten belüli elhelyezkedésének vizsgálatából kiderült, hogy a mutációknak nem volt hatása a HynSL és a sejtmembrán között lévő kölcsönhatásokra, a mutáns Hyn fehérjék továbbra is membránhoz asszociáltak maradtak. A szolubilis frakciókat tartalmazó minták esetén tapasztalt enzimaktivitás hátterében pedig az állhat, hogy a pozitív kontrollban is és a mutáns törzsekben is a HynSL hidrogenáz a pTHOE5M vektorról fejeződik ki, míg az éréshez és a transzporthoz szükséges fehérjék továbbra is a genomról expresszálódnak. Így ez utóbbiak aránya az egyes hidrogenáz alegységekhez képest kisebb lesz, aminek következtében elképzelhető, hogy nem az összes érett fehérje tud a membránba transzportálódni. Továbbá azt is érdemes megjegyezni, hogy a Hyn enzim tisztítása során 
korábban azt tapasztalták, hogy a HynSL fehérjék csak gyengén kapcsolódnak a membránhoz, arról könnyen lemoshatóak (Kovacs és mts., 1985). Hasonló dolog történhetett a munkám során használt sejtfeltárási módszer alkalmazásakor is, hiszen a szonikálás nem a legkíméletesebb módja a sejtek feltárásának.

Az egyszeres és többszörös hisztidin mutánsokkal elvégzett további in vivo és in vitro hidrogenáz aktivitásmérésekböl kiderült, hogy csak a His104-nek van jelentős szerepe a HynSL enzimatikus funkcióiban. Felvetödött tehát a kérdés, hogy ezen egyetlen aminosav miként lehet képes befolyásolni az enzim aktivitását, míg a motívum többi aminosavának hiánya nincs hatással az enzim müködésére.

A His-mutánsokkal végzett aktivitásmérések eredményeiből számos felvetés került elötérbe a His104 szerepét illetően. Az hamar világossá vált, hogy mutációja nem befolyásolja az aktív centrum rendes összeszerelődését, hiszen a Western hibridizációs kísérleteknél láttam, hogy az MH104A mutánsnál is a pozitív kontrollal megegyező mennyiségü, érett HynL alegység képződik a sejtekben. Ha az enzim aktív centrumának összeszerelődése során hiba történne (például az aktív centrumot körülvevő fehérjekörnyezet megváltozása miatt), az enzim bioszintézise megrekedne, és az érett fehérjét nem tudnánk detektálni (Magalon és mts., 2000, Blokesch és mts., 2002). Továbbá a strukturális elemzésekből az is kiderült, hogy a hisztidin gazdag motívumnak az aktív centrumtól való távolsága túl nagy az azt alkotó fémionokkal való közvetlen kölcsönhatáshoz (4. táblázat). A hidrogenázok katalitikus reakcióihoz nélkülözhetetlen molekuláris hidrogén aktív centrumhoz, illetve az aktív centrumtól a fehérje felszínére juttatására szolgáló csatorna is már jól ismert (Dole és mts., 1997), melyben az általam vizsgált hisztidinek nem érintettek. 
4. Táblázat: Az aktív centrumban lévő Ni atom és a konzervált hisztidinek tömegközéppontja közötti távolság a Desulfovibrio vulgaris Miyazaki F.-ben

\begin{tabular}{|cc|}
\hline $\begin{array}{c}\text { Desulfovibrio vulgaris Miyazaki F.- } \\
\text { ben lévó konzervált His-ek }\end{array}$ & d(Ni-COM) $(\AA)^{\mathbf{b}}$ \\
\hline His 122 & 12.004 \\
His 124 & 11.685 \\
His 127 & 11.461 \\
His 130 & 15.520 \\
His 132 & 15.849 \\
\hline
\end{tabular}

${ }^{a}$ A Desulfovibrio vulgaris Miyazaki F. His122, His124, His127, His130, His132 aminosavai a T. roseopersicina His102, His104, His107, His110, His112 aminosavainak felelnek meg.

${ }^{\mathrm{b}} \mathrm{Az}$ adott aminosav tömegközéppontja.

A hisztidineknek számos feladata lehet a fehérjékben: többek között elektron- vagy protontranszfer, struktúra stabilizáció különböző ionos kölcsönhatások révén, vagy fémek illetve redox kofaktorok kötése. A Desulfovibrio fajok [NiFe] hidrogenázaiban az elektronok az aktív centrum és a redox partner között a proximális [4Fe4S], a mediális [3Fe4S] és a disztális [4Fe4S] klaszterek segítségével szállítódnak. A membránkötött, periplazmatikus hidrogenázok egy citokróm b-vel alkotnak komplexet (elektronakceptor), ami révén az elektron végül a kinonra szállítódik (Fontecilla-Camps és mts., 2007). Mivel a kérdéses hisztidin-gazdag fehérjerészlet távol helyezkedik el a feltételezett elektrontranszfer csatornától (annak másik oldalán), így nem valószínü, hogy ezen aminosavak a hidrogenázok elektrontranszferében vesznek részt.

A hisztidinek imidazol gyürüjük révén protonálódásra is képesek. Protonálódásuk nemcsak az imidazol oldallánc töltését és sav-bázis tulajdonságát változtatja meg, de a gyürü nukleofil és elektrofil sajátosságait is, így ezek a különleges aminosavak kiváló jelöltek lehetnek a redox enzimekben protoncsatorna kialakítására (Henderson 2001). Az eddig ismert hidrogenáz szerkezetek elemzésével számos protontranszfer útvonal jellemezésére került már sor (Volbeda és mts., 1995, Dementin és mts., 2004, Fontecilla-Camps és mts., 2007, Fdez Galvan és mts., 2008, Teixeira és mts., 2008, Ogata és mts., 2009). Viszont a korábbi szakirodalmi tanulmányokban arra is utaltak, hogy enzimkatalízis során a protontranszfer valószínűleg nem korlátozódik csupán egyetlen útvonalra (Frey és mts., 2001). A D. gigas-ban az egyik elsőként javasolt útvonal egy glutaminsavat, négy hisztidint és néhány vízmolekulát tartalmazott (Volbeda és mts., 1995). Ezen útvonalban a proton első akceptor molekulája a 
nagy alegység His72 aminosava, mely a protont az aktív centrum Ni és Fe ionját áthidaló egyik aminosavról, a Cys533-ről kapja. A későbbiekben a D. fructosovorans hidrogenázával végzett kísérletek révén egy másik lehetöség került elötérbe. Javaslatuk szerint a [NiFe] hidrogenázok nagy alegységének erősen konzervált Glu25 aminosava (D. fructosovorans szerinti számozás) nagy valószínüséggel része egy protoncsatornának, hiszen a $D$. fructosovorans-ban a Glu25 Asp-ra való cseréje következtében jelentősen lecsökkent a vizsgált hidrogenáz aktivitása, illetve a Glu25Gln mutáció teljesen meg is szüntette azt (Dementin és mts., 2004). Ugyanezen típusú mutációt a T. roseopersicina HynL alegységében én is kialakítottam, de ebben az esetben in vitro körülmények között csak felére csökkent a mutáns aktivitása a pozitív kontrollhoz képest. Ebböl azt a konklúziót vontam le, hogy a hidrogenázokban léteznie kell egyéb, alternatív protontranszfer útvonal(ak)nak is, melyek valószínüleg csak akkor „aktiválódnak”, ha a „fő” csatornának tekintett útvonal müködése korlátozott.

Számos elméleti munka foglalkozott már az elsőként a $D$. fructosovorans-ban leírt, Glu25 aminosavhoz kötődő útvonal igazolásával, illetve egyéb lehetőségek feltérképezésével (Fontecilla-Camps és mts., 2007, Fdez Galvan és mts., 2008, Teixeira és mts., 2008, Ogata és mts., 2009). Az egyik ilyen javaslat (Fontecilla-Camps és mts., 2007) első tagja a D. gigas-ban a terminális cisztein (Cys530), melyröl a proton a Glu18-ra jut. Ezt az aminosavat néhány vízmolekula követi, majd a Mg-ot koordináló Glu46 és néhány újabb vízmolekula. Ugyanezen közleményben egy másik, a Glu18 aminosavból kiinduló lehetőségtől eltérő protoncsatornát is javasoltak szintén D. gigas-ban, melynek tagjai lehetnek az Arg463 (Arg487 a $T$. roseopersicina számozásának megfelelỏen), az Asp528, a His108 (His104 a $T$. roseopersicina-ban) és az Arg404 aminosavak (Fontecilla-Camps és mts., 2007), bár ezen feltételezéseiket a szerzők a hidrogenázok kristályszerkezeteinek elemzésére alapozták, kísérlettel ez idáig nem támasztották alá.

\section{A [NiFe] hidrogenázok egy alternatív proton transzlokációs útvonala}

A [NiFe] hidrogenázok nagy alegységében talált hisztidin-gazdag motívum szerepének meghatározásához, ismereteink kibővítéséhez molekulamodellezést is használtunk. E módszer 
segítségével, a $D$. vulgaris Miyazaki F. kristályszerkezetét felhasználva egy erős hidrogénhíd kötésekkel egymáshoz kapcsolódó, konzervált aminosavakból álló hálózatot ismertünk fel (10. ábra). Ezen aminosavak konzervált módon megtalálhatóak a többi membránkötött [NiFe] hidrogenázban is (12. ábra). A különböző organizmusokra jellemző pozíciójukat az 5. táblázat mutatja.

5. Táblázat: A javasolt protoncsatornákat alkotó aminosavak számozása a különböző organizmusokban

\begin{tabular}{|c|c|c|c|c|c|}
\hline $\begin{array}{c}\text { Organizmus } \\
\text { megnevezése }\end{array}$ & \multicolumn{4}{|c|}{ Aminosavak megnevezése és pozíciója } \\
\hline $\begin{array}{c}\text { Desulfovibrio } \\
\text { vulgaris }\end{array}$ & Glu16 & Arg479 & Asp123 & His124 & Glu433 \\
\hline $\begin{array}{c}\text { Desulfovibrio } \\
\text { gigas }\end{array}$ & Glu18 & Arg463 & Asp107 & His108 & Glu417 \\
\hline $\begin{array}{c}\text { Desulfovibrio } \\
\text { fructosovorans }\end{array}$ & Glu25 & Arg506 & Asp114 & His115 & Glu431 \\
\hline $\begin{array}{c}\text { Thiocapsa } \\
\text { roseopersicina }\end{array}$ & Glu14 & Arg487 & Asp103 & His104 & Glu436 \\
\hline $\begin{array}{c}\text { Allochromatium } \\
\text { vinosum }\end{array}$ & Glu14 & Arg487 & Asp103 & His104 & Glu436 \\
\hline
\end{tabular}

A munkám során azonosított molekulaláncolat, melynek a His104-es aminosav is tagja, olyan tulajdonságokkal rendelkezik, ahol a Grotthuss mechanizmus végbemehet, tehát megfelelő jelöltje lehet egy protontranszfer útvonalnak. A dolgozatban jellemzett hisztidin-gazdag motívum többi aminosava (His102, His107, His110 és His112) nem valószínü, hogy részt vesz egy protontranszfer útvonal kialakításában, hiszen ezek az aminosavak egyrészt neutrális tulajdonságúak, másrészt hidrogénhíd kötési hálózatuk a His104-hez képest sokkal korlátozottabb. A His104 viszont egyike annak a két konzervált hisztidinnek (a His110 a másik), melyek a citoplazmatikus [NiFe] hidrogenázok nagy alegységében is általánosan előfordulnak. Mindez megerösíti azt a feltételezést, hogy a His104-nek fontos szerepe lehet a [NiFe] hidrogenázok müködésében, függetlenül azok sejten belüli elhelyezkedésétöl. Ahogyan azt már az Irodalmi áttekintés és az Eredmények címü fejezetekben is említettem, egy elméleti módszerekkel meghatározott útvonal szerint az Arg463 és His108 aminosavak (melyek 
megfelelnek az Arg487 és His104-nek a T. roseopersicina HynL-ben) tagjai lehetnek egy protontranszfer rendszernek (Fontecilla-Camps és mts., 2007). Az itt megjelölt két aminosav

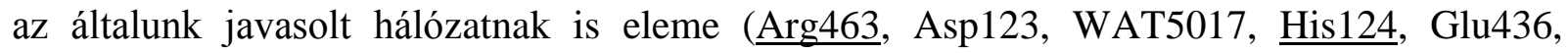
Gln390, WAT5079, WAT5115, Lys315; D. vulgaris szerinti számozás). Az elöbbi közlemény szerint az L3 konzervált motívum két másik hisztidin aminosava (His107 és His112 a $T$. roseopersicina-ban) is része az általuk feltételezett útvonalnak.

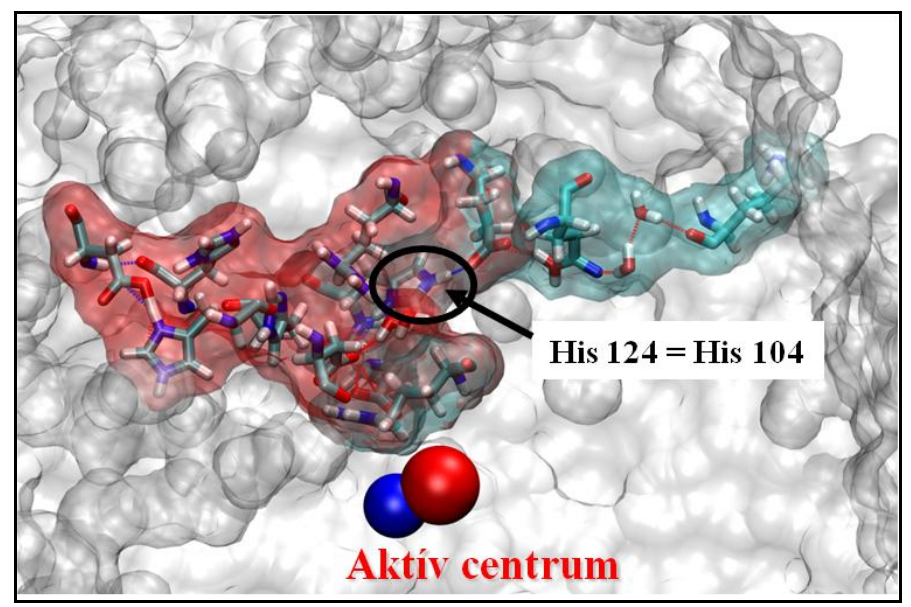

14. ábra: Feltételezett protontranszfer útvonalak térbeli elhelyezkedése a Desulfovibrio vulgaris Miyazaki F. HynB fehérjében. Piros háttérrel jelzett útvonal a Fontecilla-Camps és mts. által 2007-ben közölt lehetséges csatornát jelenti, míg kék háttérrel az általunk javasolt útvonal látható. A sötétkék gömb jelöli a Ni, míg a piros a Fe atomot.

Kísérleteim során azonban kiderült, hogy a His107 és a His112 mutációja nem befolyásolja a hidrogenáz enzim aktivitását (3. táblázat), így az kevéssé valószínü, hogy ez a két említett aminosav tagja lehet egy protontranszfer útvonalnak. A Fontecilla-Camps és mts. által javasolt útvonal további elemei alapvetően eltérnek az általam lehetségesnek vélt hálózat tagjaitól (14. ábra). Ezért dolgozatomban egy újabb lehetőséget javasoltam, hogyan valósulhat meg protontranszfer az enzim aktív centruma és a felszíne között.

Annak érdekében, hogy tisztázzam javaslatom helyességét, további aminosav mutáns törzseket készítettem (MR487I, MD103L, MH104F, ME436I; a törzsek részletes leírását az 1. táblázat tartalmazza). Elsősorban a feltételezésem szerinti útvonal első három aminosavára fókuszáltam (Arg487, Asp103, His104), mivel az utána következö aminosav, a Glu436, néhány membránkötött [NiFe] hidrogenázban nem konzervált helyzetü (pl. a $D$. gigas és a $D$. 
desulfuricans esetében a hidrogenáz nagy alegységében a kérdéses pozícióban Gln található a Glu helyett). A dolgozatban jellemzett útvonalban a His104-es aminosavat a Glu436 követi, így a His104, az öt körülvevő vízmolekuláknak köszönhetően lehet a különböző alternatív útvonalak kapcsolódási és egyben elágazódási pontja is. A korábbi protontranszfer útvonalakról általánosságban elmondható, hogy elsősorban a szulfát-redukáló, Desulfovibrio nemzetségbe tartozó baktériumok [NiFe] hidrogenázainak rendelkezésre álló fehérjeszerkezetei alapján határozták meg őket. Ha összehasonlítjuk a különböző Desulfovibrio fajokban meghatározott útvonalakat, megállapíthatjuk, hogy az egyes protoncsatornák tagjai csak az aktív centrum Ni ionja közelében konzerváltak, közeledve a fehérje felszíne felé az adott útvonalak aminosavai kevésbé konzisztensek.

Kísérleteimből az Arg487 és Asp103 esetében egyértelmüen kiderült, hogy esszenciális szerepet játszanak az enzim müködésében. A His104 szintén nagyon fontos, hiszen helyettesítése más aminosavval drasztikusan lecsökkentette a HynSL aktivitását. Az útvonal további tagjainak cseréje kevésbé befolyásolta az enzimatikus folyamatokat. Az Arg487-nek feltehetően kettős szerepe is lehet, hiszen hiánya nem csak az enzim aktivitására, de már annak érési folyamatára is hatással lehet (13. ábra). Az aktív centrumban lévő Ni és Fe ionok koordinációját a már korábban jól jellemzett CxxC motívum cisztein aminosavai végzik, de a szintén a Ni közelében lévő Arg487 is fontos szerepet játszhat ebben, hiszen a vashoz kapcsolódó $\mathrm{CN}^{-}$ligandokkal két hidrogénhíd kötés kialakítására képes (DeLacey és mts., 2003), ezáltal tehát részt vehet az aktív centrum megfelelő struktúrájának kialakításában, így pedig hatással lehet a $[\mathrm{NiFe}]$ hidrogenázok katalitikus folyamataira is. A többi mutáns esetében viszont elmondható, hogy az aminosav cserék az enzim érését nem befolyásolták, minden esetben az érett nagy alegység kialakulását igazolni tudtam (13. ábra), tehát a mutáció a megfelelően szintetizálódott HynSL enzim müködésében okoz változást.

A dolgozatomban leírt kísérletek segítségével vizsgáltam a membránkötött [NiFe] hidrogenázok nagy alegységében található His-gazdag motívum milyen szerepet tölthet be az enzimek működésében, és kiderült, hogy egyedül a His104 rendelkezik az enzim aktivitását befolyásoló szereppel, és ez az aminosav tagja lehet egy alternatív protontranszfer útvonalnak. A T. roseopersicina HynL fehérjében irányított mutagenezissel megváltoztatva a vad típusú, aktív centrum környezetében lévő fehérjemátrix aminosav összetételét, sikerült kísérletekkel is alátámasztani a bioinformatika eszközeivel javasolt - a His104-t is tartalmazó - hidrogénhíd 
kötésekkel összekapcsolódó hálózat jelentőségét a [NiFe] hidrogenázokban. Eredményeimet összevetve szakirodalmi ismeretekkel, feltételeztem, hogy a jellemzett hidrogénhíd hálózat protontranszfer útvonalként szerepelhet a hidrogenázokban.

Ezen protoncsatorna érdekessége, hogy a korábbiakban leírt útvonalakkal bár van átfedő régiója, mégis alapvetően másként helyezkedik el a fehérjében; a nagy alegység kis alegységgel (mely az elektrontranszferben szerepet játszó FeS klasztereket tartalmazza) szembeni oldalán található. Ebben a munkában elsőként sikerült a molekula-modellezésből származó eredményeket kísérletesen (a javasolt protontranszfer útvonalat alkotó, erősen konzervált aminosavak szisztematikus kicserélésével) is igazolni egy, a már jól ismert Desulfovibrio fajoktól eltérő organizmusban. Az általunk javasolt útvonal föbb elemei azonosíthatóak a $T$. roseopersicina-val közeli rokonságban lévő $A$. vinosum kristályszerkezetében is, ami további bizonyítékaként szolgálhat a bioinformatikai módszerekkel felderített és kísérletekkel is alátámasztott modell helyességére. 


\section{Köszönetnyilvánítás}

Köszönetet szeretnék mondani az SzTE Biotechnológiai Tanszék és az MTA Szegedi Biológiai Kutatóközpont Biofizikai Intézet minden dolgozójának, hogy segítették munkámat.

Szeretném megköszönni Prof. Kovács Kornélnak, hogy lehetővé tette munkámat a Biotechnológiai Tanszéken, és

Dr. Rákhely Gábornak, hogy egyetemi és Ph.D. tanulmányaim alatt irányítása alatt dolgozhattam. Köszönöm értékes szakmai tanácsait, bátorítását és támogatását.

Külön köszönet illeti Dr. Maróti Gergelyt, aki ötletgazdája volt a témának, mely dolgozatom alapját jelentette. Megismertetett a projekthez tartozó alapvető molekuláris biológiai technikákkal, és hogy mindig bizalommal fordulhattam hozzá szakmai tanácsokért, s figyelemmel követte a téma alakulását akkor is, mikor már nem volt szerves tagja a csoportunknak.

Hálás vagyok Herbel Zsófiának, Latinovics Dórának és Nyilasi Andreának a barátságukért, a tanulságos beszélgetésekért, munkámhoz nyújtott önzetlen segítségükért és ötleteikért, valamint Verebély Rózsának nélkülözhetetlen technikai segítségéért, lelki támogatásáért.

Köszönettel tartozom férjemnek, Dr. Szöri Milánnak a Ph.D. dolgozatom megírása során nyújtott nélkülözhetetlen segítségéért, szakmai tanácsaiért, illetve hogy mindig számíthattam támogatására.

Továbbá családomnak, akik tanulmányaim során mindvégig bíztattak, támogattak, akikre szintén mindig számíthattam. 


\section{Irodalomjegyzék}

Adams M. W. (1990). The structure and mechanism of iron-hydrogenases. Biochim. Biophys. Acta, 1020, 115-145.

Afting C., Hochheimer A., Thauer R. K. (1998). Function of H2-forming methylenetetrahydromethanopterin dehydrogenase from methanobacterium thermoautotrophicum in coenzyme F420 reduction with H2. Arch. Microbiol., 169, 206-210.

Albracht S. P. (1994). Nickel hydrogenases: in search of the active site. Biochim. Biophys. Acta, 1188, 167-204.

Appel J., Schulz R. (1996). Sequence analysis of an operon of a NAD(P)-reducing nickel hydrogenase from the cyanobacterium Synechocystis sp. PCC 6803 gives additional evidence for direct coupling of the enzyme to NAD(P)H-dehydrogenase (complex I). Biochim. Biophys. Acta, 1298, 141-147.

Ausubel F. M. (1995). Current Protocols in Molecular Biology, John Wiley \& Sons.

Black L. K., Fu C., Maier R. J. (1994). Sequences and characterization of hupU and hupV genes of Bradyrhizobium japonicum encoding a possible nickel-sensing complex involved in hydrogenase expression. J. Bacteriol., 176, 7102-7106.

Blokesch M., Albracht S. P., Matzanke B. F. és mts., (2004). The complex between hydrogenase-maturation proteins $\mathrm{HypC}$ and $\mathrm{HypD}$ is an intermediate in the supply of cyanide to the active site iron of [NiFe]-hydrogenases. J. Mol. Biol., 344, 155-167.

Blokesch M., Bock A. (2002). Maturation of [NiFe]-hydrogenases in Escherichia coli: the HypC cycle. J. Mol. Biol., 324, 287-296.

Bogorov L. V. (1974). [The properties of Thiocapsa roseopersicina, strain BBS, isolated from an estuary of the White Sea]. Mikrobiologiia, 43, 326-332.

Bohm R., Sauter M., Bock A. (1990). Nucleotide sequence and expression of an operon in Escherichia coli coding for formate hydrogenlyase components. Mol. Microbiol., 4, 231-243.

Brown E. C., Mucha M., Jungwirth P., Tobias D. J. (2005). Structure and vibrational spectroscopy of salt water/air interfaces: predictions from classical molecular dynamics simulations. J. Phys. Chem. B, 109, 7934-7940.

Buhrke T., Lenz O., Krauss N., Friedrich B. (2005). Oxygen tolerance of the H2-sensing [NiFe] hydrogenase from Ralstonia eutropha H16 is based on limited access of oxygen to the active site. J. Biol. Chem., 280, 23791-23796. 
Burgdorf T., De Lacey A. L., Friedrich B. (2002). Functional analysis by site-directed mutagenesis of the NAD(+)-reducing hydrogenase from Ralstonia eutropha. J. Bacteriol., 184, 6280-6288.

Cammack R., Frey M., Robson R. (2001). Hydrogen as a Fuel: Learning from Nature. London, Taylor \& Francis Inc.

CCG (2007). Molecular Operating Environment (MOE 2007.09), 1255 University St., Suite 1600, Montreal, Quebec, Canada.

Colbeau A., Kovacs K. L., Chabert J., Vignais P. M. (1994). Cloning and sequence of the structural (hupSLC) and accessory (hupDHI) genes for hydrogenase biosynthesis in Thiocapsa roseopersicina. Gene, 140, 25-31.

de Lacey A. L., Fernandez V. M., Rousset M. (2005). Native and mutant nickel-iron hydrogenases: Unravelling structure and function. Coord. Chem. Rev., 249, 1596-1608.

DeLacey A. L., Fernandez V. M., Rousset M., Cavazza C., Hatchikian E. C. (2003). Spectroscopic and kinetic characterization of active site mutants of Desulfovibrio fructosovoransNi-Fe hydrogenase. J. Biol. Inorg. Chem., 8, 129-134.

Dementin S., Belle V., Bertrand P. és mts., (2006). Changing the ligation of the distal [4Fe4S] cluster in NiFe hydrogenase impairs inter- and intramolecular electron transfers. J. Am. Chem. Soc., 128, 5209-5218.

Dementin S., Burlat B., De Lacey A. L. és mts., (2004). A glutamate is the essential proton transfer gate during the catalytic cycle of the [NiFe] hydrogenase. J. Biol. Chem., 279, 1050810513.

Dementin S., Leroux F., Cournac L. és mts., (2009). Introduction of methionines in the gas channel makes [NiFe] hydrogenase aero-tolerant. J. Am. Chem. Soc., 131, 10156-10164.

Dischert W., Vignais P. M., Colbeau A. (1999). The synthesis of Rhodobacter capsulatus HupSL hydrogenase is regulated by the two-component HupT/HupR system. Mol. Microbiol., 34, 995-1006.

Dole F., Fournel A., Magro V. és mts., (1997). Nature and electronic structure of the Ni-X dinuclear center of Desulfovibrio gigas hydrogenase. Implications for the enzymatic mechanism. Biochemistry, 36, 7847-7854.

Duche O., Elsen S., Cournac L., Colbeau A. (2005). Enlarging the gas access channel to the active site renders the regulatory hydrogenase HupUV of Rhodobacter capsulatus $\mathrm{O} 2$ sensitive without affecting its transductory activity. FEBS J., 272, 3899-3908.

Fdez Galvan I., Volbeda A., Fontecilla-Camps J. C., Field M. J. (2008). A QM/MM study of proton transport pathways in a [NiFe] hydrogenase. Proteins, 73, 195-203.

Fodor B. D. (nem közölt munka). 
Fontecilla-Camps J. C., Volbeda A., Cavazza C., Nicolet Y. (2007). Structure/function relationships of [NiFe]- and [FeFe]-hydrogenases. Chem. Rev., 107, 4273-4303.

Fox J. D., He Y., Shelver D., Roberts G. P., Ludden P. W. (1996). Characterization of the region encoding the $\mathrm{CO}$-induced hydrogenase of Rhodospirillum rubrum. J. Bacteriol., 178, 6200-6208.

Fox J. D., Kerby R. L., Roberts G. P., Ludden P. W. (1996). Characterization of the COinduced, CO-tolerant hydrogenase from Rhodospirillum rubrum and the gene encoding the large subunit of the enzyme. J. Bacteriol., 178, 1515-1524.

Frey M., Fontecilla-Camps J., Volbeda A. (2001). Handbook of metalloproteins. Chichester, UK, Wiley.

Friedrich B., Schwartz E. (1993). Molecular biology of hydrogen utilization in aerobic chemolithotrophs. Annu. Rev. Microbiol., 47, 351-383.

Fu C., Olson J. W., Maier R. J. (1995). HypB protein of Bradyrhizobium japonicum is a metal-binding GTPase capable of binding 18 divalent nickel ions per dimer. Proc. Natl. Acad. Sci. U. S. A., 92, 2333-2337.

Garcin E., Vernede X., Hatchikian E. C. és mts., (1999). The crystal structure of a reduced [NiFeSe] hydrogenase provides an image of the activated catalytic center. Structure, 7, 557566.

Hammes-Schiffer S., Stuchebrukhov A. A. (2010). Theory of coupled electron and proton transfer reactions. Chem. Rev., 110, 6939-6960.

Happe R. P., Roseboom W., Pierik A. J., Albracht S. P., Bagley K. A. (1997). Biological activation of hydrogen. Nature, $\mathbf{3 8 5}, 126$.

Happe T., Schutz K., Bohme H. (2000). Transcriptional and mutational analysis of the uptake hydrogenase of the filamentous cyanobacterium Anabaena variabilis ATCC 29413. J. Bacteriol., 182, 1624-1631.

Hartmann G. C., Klein A. R., Linder M., Thauer R. K. (1996). Purification, properties and primary structure of H2-forming N5, N10 -methylenetetrahydromethanopterin dehydrogenase from Methanococcus thermolithotrophicus. Arch. Microbiol., 165, 187-193.

Henderson L. M. (2001). NADPH oxidase subunit gp91phox: a proton pathway. Protoplasma, 217, 37-42.

Herrero M., de Lorenzo V., Timmis K. N. (1990). Transposon vectors containing nonantibiotic resistance selection markers for cloning and stable chromosomal insertion of foreign genes in gram-negative bacteria. J. Bacteriol., 172, 6557-6567. 
Higuchi Y., Yagi T., Yasuoka N. (1997). Unusual ligand structure in Ni-Fe active center and an additional $\mathrm{Mg}$ site in hydrogenase revealed by high resolution X-ray structure analysis. Structure, 5, 1671-1680.

Humphrey W., Dalke A., Schulten K. (1996). VMD: visual molecular dynamics. J. Mol. Graph., 14, 33-38, 27-38.

Inoue H., Nojima H., Okayama H. (1990). High efficiency transformation of Escherichia coli with plasmids. Gene, 96, 23-28.

Keen N. T., Tamaki S., Kobayashi D., Trollinger D. (1988). Improved broad-host-range plasmids for DNA cloning in gram-negative bacteria. Gene, 70, 191-197.

Kim D. H., Kim M. S. (2011). Hydrogenases for biological hydrogen production. Bioresour. Technol., 102, 8423-8431.

Kleihues L., Lenz O., Bernhard M., Buhrke T., Friedrich B. (2000). The H(2) sensor of Ralstonia eutropha is a member of the subclass of regulatory [NiFe] hydrogenases. $J$. Bacteriol., 182, 2716-2724.

Kondratieva E. N., Zhukov V. G., Ivanovsky R. N., Petushkova U. P., Monosov E. Z. (1976). The capacity of phototrophic sulfur bacterium Thiocapsa roseopersicina for chemosynthesis. Arch. Microbiol., 108, 287-292.

Kovacs A. T., Rakhely G., Balogh J. és mts., (2005). Hydrogen independent expression of hupSL genes in Thiocapsa roseopersicina BBS. FEBS J., 272, 4807-4816.

Kovacs A. T., Rakhely G., Browning D. F. és mts., (2005). An FNR-type regulator controls the anaerobic expression of hyn hydrogenase in Thiocapsa roseopersicina. J. Bacteriol., 187, 2618-2627.

Kovacs K. L., Bagyinka C. (1990). Structural-Properties, Functional-States and Physiological Roles of Hydrogenase in Photosynthetic Bacteria. FEMS Microbiol. Rev., 87, 407-411.

Kovacs K. L., Kovacs A. T., Maroti G. és mts., (2005). The hydrogenases of Thiocapsa roseopersicina. Biochem. Soc. Trans., 33, 61-63.

Kovacs K. L., Maroti G., Rakhely G. (2006). A novel approach for biohydrogen production. Int. J. Hydrogen Energy, 31, 1460-1468.

Kovacs K. L., Tigyi G., Alfonz H. (1985). Purification of hydrogenase by fast protein liquid chromatography and by conventional separation techniques: a comparative study. Prep. Biochem., 15, 321-334.

Kunkel A., Vorholt J. A., Thauer R. K., Hedderich R. (1998). An Escherichia coli hydrogenase-3-type hydrogenase in methanogenic archaea. Eur. J. Biochem., 252, 467-476. 
Labute P. (2009). Protonate3D: assignment of ionization states and hydrogen coordinates to macromolecular structures. Proteins, 75, 187-205.

Lenz O., Bernhard M., Buhrke T., Schwartz E., Friedrich B. (2002). The hydrogen-sensing apparatus in Ralstonia eutropha. J. Mol. Microbiol. Biotechnol., 4, 255-262.

Leroux F., Dementin S., Burlat B. és mts., (2008). Experimental approaches to kinetics of gas diffusion in hydrogenase. Proc. Natl. Acad. Sci. U. S. A., 105, 11188-11193.

Leys D., Scrutton N. S. (2004). Electrical circuitry in biology: emerging principles from protein structure. Curr. Opin. Struct. Biol., 14, 642-647.

Liebgott P. P., Leroux F., Burlat B. és mts., (2010). Relating diffusion along the substrate tunnel and oxygen sensitivity in hydrogenase. Nat. Chem. Biol., 6, 63-70.

Magalon A., Bock A. (2000). Analysis of the HypC-hycE complex, a key intermediate in the assembly of the metal center of the Escherichia coli hydrogenase 3. J. Biol. Chem., 275, 21114-21120.

Maroti G., Fodor B. D., Rakhely G. és mts., (2003). Accessory proteins functioning selectively and pleiotropically in the biosynthesis of [NiFe] hydrogenases in Thiocapsa roseopersicina. Eur. J. Biochem., 270, 2218-2227.

Maroti G., Rakhely G., Maroti J. és mts., (2010). Specificity and selectivity of HypC chaperonins and endopeptidases in the molecular assembly machinery of [ $\mathrm{NiFe}$ ] hydrogenases of Thiocapsa roseopersicina. Int. J. Hydrogen Energy, 35, 3358-3370.

Maroti J., Farkas A., Nagy I. K. és mts., (2010). A second soluble Hox-type NiFe enzyme completes the hydrogenase set in Thiocapsa roseopersicina BBS. Appl. Environ. Microbiol., 76, 5113-5123.

Marques M. C., Coelho R., De Lacey A. L., Pereira I. A., Matias P. M. (2010). The threedimensional structure of [NiFeSe] hydrogenase from Desulfovibrio vulgaris Hildenborough: a hydrogenase without a bridging ligand in the active site in its oxidised, "as-isolated" state. $J$. Mol. Biol., 396, 893-907.

Matias P. M., Soares C. M., Saraiva L. M. és mts., (2001). [NiFe] hydrogenase from Desulfovibrio desulfuricans ATCC 27774: gene sequencing, three-dimensional structure determination and refinement at $1.8 \mathrm{~A}$ and modelling studies of its interaction with the tetrahaem cytochrome c3. J. Biol. Inorg. Chem., 6, 63-81.

Montet Y., Amara P., Volbeda A. és mts., (1997). Gas access to the active site of Ni-Fe hydrogenases probed by X-ray crystallography and molecular dynamics. Nat. Struct. Biol., 4, 523-526.

Mus-Veteau I., Guerlesquin F. (1994). Involvement of histidine residues in the catalytic mechanism of hydrogenases. Biochem. Biophys. Res. Commun., 201, 128-134. 
Nicolet Y., Piras C., Legrand P., Hatchikian C. E., Fontecilla-Camps J. C. (1999). Desulfovibrio desulfuricans iron hydrogenase: the structure shows unusual coordination to an active site Fe binuclear center. Structure, 7, 13-23.

Ogata H., Hirota S., Nakahara A. és mts., (2005). Activation process of [NiFe] hydrogenase elucidated by high-resolution X-ray analyses: conversion of the ready to the unready state. Structure, 13, 1635-1642.

Ogata H., Kellers P., Lubitz W. (2010). The crystal structure of the [NiFe] hydrogenase from the photosynthetic bacterium Allochromatium vinosum: characterization of the oxidized enzyme (Ni-A state). J. Mol. Biol., 402, 428-444.

Ogata H., Lubitz W., Higuchi Y. (2009). [NiFe] hydrogenases: structural and spectroscopic studies of the reaction mechanism. Dalton Trans., 7577-7587.

Oh Y. K., Raj S. M., Jung G. Y., Park S. (2011). Current status of the metabolic engineering of microorganisms for biohydrogen production. Bioresour. Technol., 102, 8357-8367.

Oxelfelt F., Tamagnini P., Lindblad P. (1998). Hydrogen uptake in Nostoc sp. strain PCC 73102. Cloning and characterization of a hupSL homologue. Arch. Microbiol., 169, 267-274.

Page C. C., Moser C. C., Dutton P. L. (2003). Mechanism for electron transfer within and between proteins. Curr. Opin. Chem. Biol., 7, 551-556.

Palagyi-Meszaros L. S., Maroti J., Latinovics D. és mts., (2009). Electron-transfer subunits of the NiFe hydrogenases in Thiocapsa roseopersicina BBS. FEBS J., 276, 164-174.

Peters J. W. (1999). Structure and mechanism of iron-only hydrogenases. Curr. Opin. Struct. Biol., 9, 670-676.

Peters J. W., Lanzilotta W. N., Lemon B. J., Seefeldt L. C. (1998). X-ray crystal structure of the Fe-only hydrogenase $(\mathrm{CpI})$ from Clostridium pasteurianum to 1.8 angstrom resolution. Science, 282, 1853-1858.

Pfennig N., Truper H. G. (1983). Taxonomy of phototrophic green and purple bacteria: a review. Ann. Microbiol. (Paris), 134B, 9-20.

Pierik A. J., Roseboom W., Happe R. P., Bagley K. A., Albracht S. P. (1999). Carbon monoxide and cyanide as intrinsic ligands to iron in the active site of [NiFe]-hydrogenases. $\mathrm{NiFe}(\mathrm{CN}) 2 \mathrm{CO}$, Biology's way to activate H2. J. Biol. Chem., 274, 3331-3337.

Rakhely G., Colbeau A., Garin J., Vignais P. M., Kovacs K. L. (1998). Unusual organization of the genes coding for HydSL, the stable [NiFe]hydrogenase in the photosynthetic bacterium Thiocapsa roseopersicina BBS. J. Bacteriol., 180, 1460-1465.

Rakhely G., Kovacs A. T., Maroti G. és mts., (2004). Cyanobacterial-type, heteropentameric, NAD+-reducing NiFe hydrogenase in the purple sulfur photosynthetic bacterium Thiocapsa roseopersicina. Appl. Environ. Microbiol., 70, 722-728. 
Rakhely G., Laurinavichene T. V., Tsygankov A. A., Kovacs K. L. (2007). The role of Hox hydrogenase in the $\mathrm{H} 2$ metabolism of Thiocapsa roseopersicina. Biochim. Biophys. Acta, 1767, 671-676.

Reece S. Y., Nocera D. G. (2009). Proton-coupled electron transfer in biology: results from synergistic studies in natural and model systems. Annu. Rev. Biochem., 78, 673-699.

Reissmann S., Hochleitner E., Wang H. és mts., (2003). Taming of a poison: biosynthesis of the NiFe-hydrogenase cyanide ligands. Science, 299, 1067-1070.

Rossi M., Pollock W. B., Reij M. W. és mts., (1993). The hmc operon of Desulfovibrio vulgaris subsp. vulgaris Hildenborough encodes a potential transmembrane redox protein complex. J. Bacteriol., 175, 4699-4711.

Rousset M., Montet Y., Guigliarelli B. és mts., (1998). [3Fe-4S] to [4Fe-4S] cluster conversion in Desulfovibrio fructosovorans [NiFe] hydrogenase by site-directed mutagenesis. Proc. Natl. Acad. Sci. U. S. A., 95, 11625-11630.

Sambrook J., Fritsch E. F., Maniatis T. (1989). Molecular Cloning: A Laboratory Manual. New York, Cold Spring Harbor Laboratory Press.

Sapra R., Verhagen M. F., Adams M. W. (2000). Purification and characterization of a membrane-bound hydrogenase from the hyperthermophilic archaeon Pyrococcus furiosus. $J$. Bacteriol., 182, 3423-3428.

Sargent F., Berks B. C., Palmer T. (2006). Pathfinders and trailblazers: a prokaryotic targeting system for transport of folded proteins. FEMS Microbiol. Lett., 254, 198-207.

Sargent F., Stanley N. R., Berks B. C., Palmer T. (1999). Sec-independent protein translocation in Escherichia coli. A distinct and pivotal role for the TatB protein. J. Biol. Chem., 274, 36073-36082.

Sauter M., Bohm R., Bock A. (1992). Mutational analysis of the operon (hyc) determining hydrogenase 3 formation in Escherichia coli. Mol. Microbiol., 6, 1523-1532.

Schmitz O., Boison G., Salzmann H. és mts., (2002). HoxE--a subunit specific for the pentameric bidirectional hydrogenase complex (HoxEFUYH) of cyanobacteria. Biochim. Biophys. Acta, 1554, 66-74.

Schneider K., Schlegel H. G. (1976). Purification and properties of soluble hydrogenase from Alcaligenes eutrophus H 16. Biochim. Biophys. Acta, 452, 66-80.

Silva P. J., van den Ban E. C., Wassink H. és mts., (2000). Enzymes of hydrogen metabolism in Pyrococcus furiosus. Eur. J. Biochem., 267, 6541-6551.

Szilagyi A., Kovacs K. L., Rakhely G., Zavodszky P. (2002). Homology modeling reveals the structural background of the striking difference in thermal stability between two related [NiFe]hydrogenases. J. Mol. Model., 8, 58-64. 
Tamagnini P., Axelsson R., Lindberg P. és mts., (2002). Hydrogenases and hydrogen metabolism of cyanobacteria. Microbiol. Mol. Biol. Rev., 66, 1-20, table of contents.

Teixeira V. H., Baptista A. M., Soares C. M. (2006). Pathways of H2 toward the active site of [NiFe]-hydrogenase. Biophys. J., 91, 2035-2045.

Teixeira V. H., Soares C. M., Baptista A. M. (2008). Proton pathways in a [NiFe]hydrogenase: A theoretical study. Proteins, 70, 1010-1022.

Tersteegen A., Hedderich R. (1999). Methanobacterium thermoautotrophicum encodes two multisubunit membrane-bound [NiFe] hydrogenases. Transcription of the operons and sequence analysis of the deduced proteins. Eur. J. Biochem., 264, 930-943.

Theodoratou E., Huber R., Bock A. (2005). [NiFe]-Hydrogenase maturation endopeptidase: structure and function. Biochem. Soc. Trans., 33, 108-111.

Vignais P. M., Billoud B. (2007). Occurrence, classification, and biological function of hydrogenases: An overview. Chem. Rev., 107, 4206-4272.

Vignais P. M., Billoud B., Meyer J. (2001). Classification and phylogeny of hydrogenases. FEMS Microbiol. Rev., 25, 455-501.

Vignais P. M., Colbeau A. (2004). Molecular biology of microbial hydrogenases. Curr. Issues Mol. Biol., 6, 159-188.

Visscher P. T., Nijburg J. W., Vangemerden H. (1990). Polysulfide utilization by thiocapsaroseopersicina. Arch. Microbiol., 155, 75-81.

Volbeda A., Charon M. H., Piras C. és mts., (1995). Crystal structure of the nickel-iron hydrogenase from Desulfovibrio gigas. Nature, 373, 580-587.

Volbeda A., Garcin E., Piras C. és mts., (1996). Structure of the [NiFe] hydrogenase active site: Evidence for biologically uncommon Fe ligands. J. Am. Chem. Soc., 118, 12989-12996.

Volbeda A., Montet Y., Vernede X., Hatchikian E. C., Fontecilla-Camps J. C. (2002). Highresolution crystallographic analysis of Desulfovibrio fructosovorans [NiFe] hydrogenase. Int. J. Hydrogen Energy, 27, 1449-1461.

Voordouw G., Menon N. K., LeGall J. és mts., (1989). Analysis and comparison of nucleotide sequences encoding the genes for [NiFe] and [NiFeSe] hydrogenases from Desulfovibrio gigas and Desulfovibrio baculatus. J. Bacteriol., 171, 2894-2899.

Yeang H. Y., Yusof F., Abdullah L. (1998). Protein purification for the Lowry assay: acid precipitation of proteins in the presence of sodium dodecyl sulfate and other biological detergents. Anal. Biochem., 265, 381-384. 
Zirngibl C., Van Dongen W., Schworer B. és mts., (1992). H2-forming methylenetetrahydromethanopterin dehydrogenase, a novel type of hydrogenase without ironsulfur clusters in methanogenic archaea. Eur. J. Biochem., 208, 511-520. 


\section{Saját közlemények jegyzéke}

\section{A dolgozat alapjául szolgáló közlemények:}

Emma Szőri-Dorogházi, Gergely Maróti, Milán Szőri, Andrea Nyilasi, Gábor Rákhely, Kornél L. Kovács (2012) Analyses of the large subunit histidine-rich motif expose an alternative proton transfer pathway in [NiFe] hydrogenases, Plos One (in press); IF(2010): 4,411

Dorogházi Emma, Prof. Kovács L. Kornél, Dr. Rákhely Gábor. (2009) Analysis of a structural motif in the membrane-associated [NiFe] hydrogenases, Acta Biologica Szegediensis, 53, 59;

\section{Egyéb közlemények:}

K.L. Kovács, Á.T. Kovács, G. Maróti, L.S. Mészáros, J. Balogh, D. Latinovics, A. Fülöp, R. Dávid, E. Dorogházi, G. Rákhely. (2005) The Hydrogenases of Thiocapsa roseopersicina, Biochemical Society Transactions, 33, 61-3; IF(2005): 3,099

Gergely Maróti, Gábor Rákhely, Judit Maróti, Emma Dorogházi, Eva Klement, Katalin F. Medzihradszky, Kornél L. Kovács. (2010) Specificity and selectivity of HypC chaperonins and endopeptidases in the molecular assembly machinery of [NiFe] hydrogenases of Thiocapsa roseopersicina, International Journal of Hydrogen Energy 35, 3358-3370; IF(2010): 4,053

K.L. Kovács, Z. Bagi, E. Kovács, G. Maróti, E. Szőri-Dorogházi, N. Ács, R. Wirth, R. Tengölics, A. Fülöp, G. Rákhely. (2011) Industrial microbiology for the production of biohydrogen and biogas, Acta Microbiologica et Immunologica Hungarica 58, 171-172; $\operatorname{IF}(2010): 0,625$ 


\section{Poszterek:}

G. Maróti, Z. Bagi, G. Rákhely, M. Takács, A. Tóth, Á.T. Kovács, Gy. Csanádi, B. Bálint, L. S. Mészáros, J. Balogh, A. Fülöp, D. Latinovics, R. Dávid, E. Dorogházi, A. Nyilasi and K.L. Kovács: Biohydrogen, biogas (World Life Sciences Forum, Lyon, 2005)

Emma Dorogházi, Gergely Maróti, Gábor Rákhely, Kornél L. Kovács: Structural-functional analysis of [Ni-Fe] hydrogenases (A Magyar Mikrobiológiai Társaság 2005. évi Nagygyülése és alst Central European Forum for Microbiology (CEFORM), Keszthely, Magyarország, 2005)

Emma Dorogházi, Gergely Maróti, Gábor Rákhely, Kornél L. Kovács: Structural motifs in the membrane-associated [NiFe] hydrogenases (16th International Conference on Photochemical Conversion and Storage os Solar Energy (IPS-16), Uppsala, Svédország, 2006)

Kornél L. Kovács, Z. Bagi, B. Bálint, J. Balogh, E. Dorogházi, Zs. Herbel, D. Latinovics, L. Mészáros, G. Maróti, K. Perei, A. Tóth, A. Varga and G. Rákhely. Biohydrogen and some biotechnological applications (International Symposium on Environmental Biocatalysis, Cordoba, Spanyolország, 2006)

Emma Dorogházi, Gergely Maróti, Laurent Cournac, Gábor Rákhely, Kornél L. Kovács: Analysis of a structural motif in the membrane-associated [NiFe] hydrogenases (Hydrogenase and Hydrogen Production 2007: The 8th International Hydrogenase Conference Breckenridge, Colorado, USA, 2007)

E. Dorogházi, D. Latinovics, G. Rákhely, and K.L. Kovács: Affinity purification and biochemical characterization of the Hyn and Hox1 hydrogenases from Thiocapsa roseopersicina BBS (Bochum, Németország, 2008) 


\section{Előadások:}

Dorogházi Emma, Prof. Kovács L. Kornél, Dr. Rákhely Gábor: [Ni-Fe] hidrogenáz enzimek struktúra-funkció analízise irányított mutagenezissel (XXVII. OTDK Biológia Szekció, Pécs, Magyarország, 2005)

Dorogházi Emma, Prof. Kovács L. Kornél, Dr. Rákhely Gábor: A Thiocapsa roseopersicina [Ni-Fe] hidrogenáz enzimek struktúra-funkció analízise (IV. Vajdasági Magyar Tudományos Diákköri Konferencia, Szabadka, Szerbia, 2005)

Dorogházi Emma, Prof. Kovács L. Kornél, Dr. Rákhely Gábor, Dr. Maróti Gergely: A membránkötött [NiFe] hidrogenáz enzimekben megtalálható szerkezeti motívum vizsgálata (VII. Vajdasági Magyar Tudományos Diákköri Konferencia, Újvidék, Szerbia, 2008)

Prof. Kovács L. Kornél, Dr. Maróti Gergely, Lívia S. Palágyi-Mészáros, Judit Maróti, Dóra Latinovics, Emma Dorogházi, Dr. Rákhely Gábor: Biohydrogen production and related enzymes (BIT's $2^{\text {nd }}$ Annual World Congress of Industrial Biotechnology, Seoul, Dél-Korea, 2009)

Emma Dorogházi, Lívia S. Palágyi-Mészáros, Edit Győri, Gergely Maróti, Gábor Rákhely, Kornél L. Kovács: Site directed mutagenesis studies on the Hyn hydrogenase of Thiocapsa roseopersicina BBS (SOLAR-H2 Workshop Berlin, Németország, 2010)

Emma Szőri-Dorogházi, Gergely Maróti, Milán Szőri, Gábor Rákhely, Kornél L. Kovács: A histidine-rich region in the Hyn hydrogenase of Thiocapsa roseopersicina: molecular biology and modeling studies (Straub Napok, Szeged, Magyarország, 2010) 


\section{X. Összefoglalás}

A T. roseopersicina hidrogenázait kutatócsoportunk több szempontból részletesen vizsgálja, sokat tudunk ezen enzimek bioszintéziséről, kifejeződésük szabályozásáról, az egyes hidrogenázok sejten belüli szerepéröl, valamint egyéb sejten belüli metabolikus útvonalakhoz való viszonyáról. Dolgozatomban a $\mathrm{Hyn}$ [NiFe] hidrogenáz struktúra-funkció kapcsolatai területén végzett kísérleteim eredményeiről számolok be.

A rendelkezésre álló, főleg a Desulfovibrio génuszból származó [NiFe] hidrogenázok kristályszerkezeteinek elemzésével számos konzervált szekvenciarészlet vagy konkrét aminosav az enzim müködésében betöltött szerepét írták már le. Munkám során ezekhez hasonlóan a $T$. roseopersicina periplazmatikus, membránhoz asszociált HynSL enzimét használva modellként, a [NiFe] hidrogenázokra általánosan jellemző, konzervált struktúrákat kerestem. A hidrogenázok elsődleges szekvenciáit megvizsgálva egy, a korábbiakban még részletesen nem jellemzett régiót találtam, mely számos hisztidin aminosavat tartalmaz egy rövid szekvenciarészletben. Ez az erösen konzervált $\mathrm{Hx} \underline{\mathrm{H}} x \mathrm{x} \mathrm{Hx} \underline{\mathrm{H}} \mathrm{xH}$ motívum jelen van minden membránkötött [NiFe] hidrogenázban, és az öt hisztidin közül kettő (a második és negyedik) helye a citoplazmatikus hidrogenázokban is rögzített.

Munkám egyik célja volt, hogy kiderítsem ezen His-gazdag motívum szerepét. A régió vizsgálatát irányított mutagenezissel kezdtem meg, mely technika lehetővé teszi adott aminosav(ak) helyspecifikus cseréjét, majd a mutagenezis következtében a vizsgált fehérje fenotípusában bekövetkező változásokból következtetni tudunk a kérdéses aminosav(ak) szerepére. A HxHxxHxxHxH régió aminosavait kódoló nukleotidok cseréjét a modellként használt hynL gén megfelelő szakaszában létrehoztam, ellenőriztem, a T. roseopersicina-ba visszajuttatandó széles gazdaspecifitású vektorokba beépítettem, majd konjugációval bejuttattam egy olyan $T$. roseopersicina törzsbe, melyben az eddig ismert hidrogenázok a genomról nem fejeződnek ki, így specifikusan tudtam vizsgálni az általam okozott mutációk következményeit a HynSL enzimre nézve. Az in vivo és in vitro hidrogenáz aktivitás mérések adataiból kiderült, hogy a vizsgált motívum második aminosavának (His104) Ala-ra való cseréje, mely mind a membránkötött, mind a citoplazmatikus [NiFe] hidrogenázok nagy alegységében konzervált helyzetü, jelentős hatással van az enzim aktivitására, míg az enzim 
lokalizációját nem változtatja meg. Western hibridizációs módszerrel igazoltam, hogy a mutációk nem befolyásolták a mutáns fehérjék proteolitikus stabilitását, tisztáztam, hogy az enzimek aktivitásbeli különbsége nem magyarázható a fehérjék sejten belüli destabilizációjával.

A HynSL fehérje nagy alegységében lévő hisztidin gazdag motívum szerepére számos feltételezés adódott. A rendelkezésre álló, membránkötött [NiFe] hidrogenázok kristályszerkezeteinek bioinformatikai elemzéséből kiderült, hogy ez a régió távol van a hidrogenázok jól jellemzett elektrontranszfer útvonalától, így valószínütlen ebben való szerepük. Viszont az enzimek nagy alegységében találtunk egy hidrogénhíd kötésekkel erősen összekapcsolódó molekula hálózatot (Arg487, Asp103, His104, Glu436), melynek tagja az általam vizsgált hisztidin-gazdag motívum második eleme is (His104). Úgy véltem ez a hálózat, tulajdonságaiból adódóan protontranszfer útvonal szerepét töltheti be az enzim müködése során.

Elkészítettem a feltételezett csatorna konzervált aminosavaiban mutáns törzseket, s a mutáns aminosavsorrendủ enzimekkel végzett hidrogenáz aktivitásmérések eredményeiből kiderült, hogy a kérdéses aminosavak cseréje befolyásolta a Hyn hidrogenáz müködését. Igazoltam, hogy az Arg487 aminosavnak, mely az általunk javasolt protontranszfer útvonal első tagja, feltehetően kettős szerepe lehet. Hiánya nem csak az enzim aktivitására, de már annak érési folyamatára is hatással volt. Feltehetően az aktív centrumban lévő Fe ion és a hozzá kapcsolódó $\mathrm{CN}^{-}$ligandok koordinációjának módosításával befolyásolta a fehérje érését, ezáltal hatva a [NiFe] hidrogenázok katalitikus folyamataira is. A többi protoncsatorna-mutáns törzs esetében a vizsgált aminosavak mutációja nem volt hatással a HynL bioszintézisére.

A számítógépes modellezés és kísérleteim eredménye alapján elmondható, hogy a His104 része egy hidrogénhíd kötésekkel erősen egymáshoz kapcsolódó molekulaláncolatnak, mely az enzim aktív centruma és felszíne között helyezkedik el. Az általam feltételezett alternatív protoncsatornát alkotó aminosavak cseréjével kísérletesen is igazoltam, hogy az Arg487, Asp103, His104 és a Glu436 mutációja hatással van a HynSL katalitikus aktivitására, így bizonyítékot nyújtva a protoncsatorna hipotézis lehetőségére. Ez az alternatív útvonal, a korábbiakban jellemzett útvonalakhoz képest a nagy alegységnek az elektrontranszferben szerepet játszó kis alegységgel szembeni oldalán található. Továbbá munkámban elsőként 
sikerült a molekulamodellezésből származó eredményeket kísérletesen (a javasolt protontranszfer útvonalat alkotó aminosavak szisztematikus kicserélésével) is igazolni egy, a már jól ismert Desulfovibrio fajoktól eltérő organizmusban is. Az általunk javasolt útvonal főbb jellemzői a $T$. roseopersicina-val közeli rokonságban lévő $A$. vinosum kristályszerkezetében is megfigyelhetőek. 


\section{Summary}

Hydrogenases of $T$. roseopersicina have been studied in several aspects by our research group. Investigations were carried out about the biosynthesis, the regulation and cellular function of different hydrogenases of our model organism, furthermore mapping the linkage of hydrogenases to other metabolic pathways in the cell. In addition it was also a good subject for examining the structure and function relationships of the Hyn [NiFe] hydrogenase. This work reports the results obtained in this field.

Crystal structures of several periplasmic membrane-associated [NiFe] hydrogenases of sulfate-reducing bacteria and one of a non sulphate-reducing bacterium have been reported so far. These structures were used as a model to study structure-function relationships of [NiFe] hydrogenases. The aim of these studies was to disclose how variations in the active site structures and their respective protein environment alter the activity of the hydrogenases. A number of highly conserved regions and conserved amino acids, typical for [NiFe] hydrogenases, and their potential functions have been reported. In the present work $T$. roseopersicina HynSL, as our model enzyme was used to study additional conserved sequences which might be important in the activity of [NiFe] hydrogenases. The sequence alignment of large subunits of [NiFe] hydrogenases showed a highly conserved histidine-rich region with unknown function. These amino acids are symmetrically arranged $(\mathrm{Hx} \underline{\mathrm{H} x \mathrm{Hxx}} \underline{\mathrm{H} x H})$ and occurs in almost all membrane-bound hydrogenases but only two of them (the second and the fourth) are present in soluble hydrogenases.

One of my aims was to elucidate the function of this His-rich region. Site-directed mutagenesis was used for the examination of this motif. This is an invaluable technique for studying protein structure-function relationships and for testing the phenotypical effect according to amino acid replacements. The adequate mutations of the HxHxxHxxHxH region were made in the hynL gene. The amino acid mutant fragments were put into wide host-range vectors and these vectors were conjugated into T. roseopersicina strain. In this adequate strain the known hydrogenases are not expressed from the genome, thus the specific effect of the mutations could be examined. The results of the in vivo and in vitro hydrogenase activity measurements showed that substitution of the second amino acid of the His-rich motif (His 104), which occurs both in the membrane-bound and in the soluble [NiFe] hydrogenases, 
had significant effect on the enzyme activity, but did not change the localization of the enzyme. Western hybridization experiments confirmed that none of these mutations alter the proteolytic stability of the proteins. Consequently this clarified that the activity changes of the mutant enzymes could not be derived from the destabilization of the proteins.

Based on the results of hydrogenase activity measurements on His mutants several hypotheses were made about the function of this motif. From the investigations of the available crystal structures of membrane-associated [NiFe] hydrogenases it was elucidated that the histidine cluster of our interest is located far from the previously proposed electron channel of the protein (on the opposite side), thereby it is unlikely that these amino acids play role in the electron transfer within the hydrogenases. However, molecular modeling calculations were carried out and a network of conserved amino acids (Arg487, Asp103, His104, Glu436), connected by strong hydrogen bonds was recognized. This result suggested that this molecular chain - with the participation of His104 - may be a good candidate for a proton transfer pathway where the Grotthuss mechanism can take place.

In order to experimentally verify that the proposed network of conserved residues acts as an alternative proton transfer pathway additional amino acid mutants were constructed. The hydrogenase activity of these mutants clearly demonstrated that the mutations had serious effect on the Hyn enzyme activity. It was confirmed that the first amino acid of the proposed proton transfer pathway, the Arg487, has dual function in [NiFe] hydrogenases. The replacement of this amino acid has influence not only on the catalytic activity, but also on the maturation processes of the enzyme. Arg487 probably have indirect role in coordinating of the Fe ion locating in the metal center, since it is capable to form two hydrogen bonds with $\mathrm{CN}^{-}$ ligands, thus it can affect the biosynthesis and thereby the enzyme activity of [NiFe] hydrogenases. In case of the other mutants of the proton channel, mutations do not influence the maturation of the HynL protein.

Based on computational modeling and experimental results it was shown that the His104 might be part of a tight hydrogen bonded molecular chain between the active site and the protein surface. It is suggested that the residues of this molecular chain might serve as an alternative proton translocation route within the enzyme. In order to test this assumption, amino acid substitutions were carried out and it was demonstrated that the mutation of Arg487, Asp103, His104 and Glu436 influence the activity of the HynSL during the catalytic 
cycle of the enzyme corroborating the proton transfer pathway hypothesis. An interesting feature of this model is, compared to previous suggestions, that this proton channel is located on the opposite side of the large subunit relative to the position of the small subunit. It should be emphasized that this is the first time when the conclusions of a molecular modeling study were checked experimentally using a model organism distinct from the well known Desulfovibrio-type ones. The general features of the proposed novel proton channel could be detected in A. vinosum structure as well, the close relative of the T. roseopersicina. 